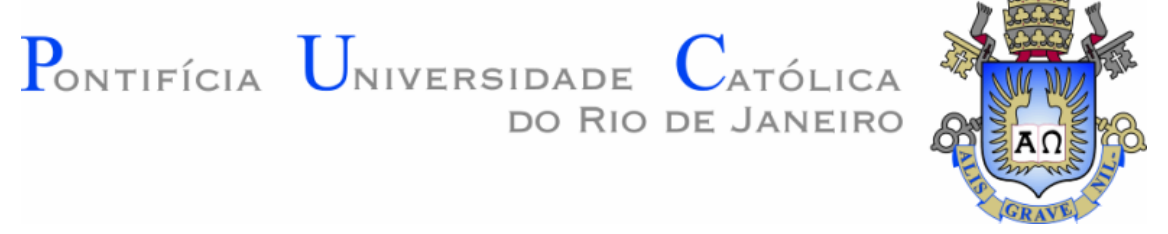

Luiza Diniz de Oliveira Camara

Lca of Electrical Vehicle Fleet with Locally Generated and Stored Renewable Energy

DISSERTAÇÃO DE MESTRADO

Dissertation presented to the Programa de PósGraduação em Engenharia Urbana e Ambiental of the Departamento de Engenharia Civil, PUC-Rio, as partial fulfillment of the requirements for the degree of Mestre em Engenharia Urbana e Ambiental (Opção Profissional).

Advisor: Prof. Celso Romanel

Rio de Janeiro

July 2015 
Luiza Diniz de Oliveira Camara

\title{
Lca of Electrical Vehicle Fleet with Locally Generated and Stored Renewable Energy
}

\begin{abstract}
Dissertation presented to the Programa de PósGraduação em Engenharia Urbana e Ambiental of the Departamento de Engenharia Civil, PUC-Rio as partial fulfillment of the requirements for the degree of Mestre em Engenharia Urbana e Ambiental (Opção Profissional).
\end{abstract}

Prof. Celso Romanel

Advisor

Departamento de Engenharia Civil - PUC-Rio

Prof. Rodrigo Flora Calili

Departamento de Engenharia Civil - PUC-Rio

Prof. Reinaldo Castro Souza

Departamento de Engenharia Civil - PUC-Rio

Prof. Fernando Luiz Cumplido Mac Dowell da Costa

Departamento de Engenharia Civil - PUC-Rio

Prof. José Eugenio Leal

Coordinator of the Centro Técnico Científico da PUC-Rio

Rio de Janeiro, July $9^{\text {th }}, 2015$. 
All rights reserved

\section{Luiza Diniz de Oliveira Camara}

The author graduated in Environmental Engineering from Pontifícia Universidade Católica do Rio de Janeiro - PUCRio in 2012. She is currently developing studies on the fields of urban mobility and renewable energies.

Bibliographic data

Camara, Luiza Diniz de Oliveira

LCA of Electric vehicle fleet with locally generated and stored renewable energy / Luiza Diniz de Oliveira Camara ; Advisor: Celso Romanel - 2015.

$91 \mathrm{f}$. : il. (color.) ; $30 \mathrm{~cm}$

Dissertação (mestrado) - Pontifícia Universidade Católica do Rio de Janeiro, Departamento de Engenharia Civil, Programa de Pós-Graduação em Engenharia Urbana e Ambiental, 2015.

Inclui bibliografia

1. Engenharia civil - Teses. 2. Electic Vehicles. 3. Renewable energy. 4. Batteries. 5. Life Cycle Assessment. I. Dettmer, Tina. II. Romanel, Celso III. Pontifícia Universidade Católica do Rio de Janeiro. Departamento de Engenharia Civil. IV. Título. 


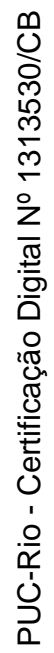

À minha Avó Wanda,

pelo exemplo de força e de perseverança. 


\section{Acknowlagements}

I would like to express my deepest appreciation to my professor Tina Dettmer, who introduced me to this area and supported my decision to finish my masters in Germany. I am also grateful to Professor Celso Romanel and Professor Christopher Hermann for embracing the idea.

I would like to thank Patricia Edge for her guidance and help. Without her guidance, and patience this work wouldn't have been possible.

I am also grateful to my parents, Fatima Diniz e Rogério Camara, who have supported every decision I've made in my life, and to my grandmother, Wanda Diniz, whose life history of courage and hard work has inspired me to seek for my own achievements. 


\section{Abstract}

Camara, Luiza Diniz de Oliveira; Romanel, Celso (advisor). LCA of vehicle fleet with locally generated and stored renewable energy. Rio de Janeiro, 2015. 91p. Master Dissertation - Departamento de Engenharia Civil, Pontifícia Universidade Católica do Rio de Janeiro.

The stated aim of the German federal government is the market preparation and launch of battery electric vehicles in Germany. The potential of electric vehicles for reducing the harmful environmental impacts of road transport in everyday conditions has to be analyzed and evaluated in detail. If electric vehicles shall realize their potential to reduce emissions and minimize the consumption of resources, the use of renewable energy is necessary. Locally generated and stored energy could increase the use of renewable energy sources for electric vehicles. A quantitative method is necessary to determine if the use of local energy is environmentally advantageous in comparison to the use of renewable energy from the grid. Life cycle assessment is a method which quantifies potential environmental impacts, and, therefore, it is a suitable method to examine the research question. The local energy provider BS|ENERGY uses electric vehicles and plans on the installation of a stationary energy storage. Within this scenario the LCA method is applyed to analyze the environmental impacts of this solution. This work carries out a detailed life cycle assessment for the local energy storage system of BS|ENERGY. To support this work a theoretic background of the method life cycle assessment and of the local generation and storage of renewable energy is presented. Based on this information, a generic workflow for the LCA of the use of locally generated and stored energy for electric vehicles is created. This workflow serves as a basis to evaluate the key parameters for the result of the LCA, identifying hot spots and uncertainties. Finally, the specific case of BS|ENERGY is analyzed, with its specific battery chemistry and use pattern. With this, it is expected that the presente work will be able to support BS Energy decision of whether to invest on the stationary battery or not, from an envirionmental point of view.

\section{Keywords}

Electric vehicles; Renewable energy; Batteries; Life Cycle Assessment. 


\section{Resumo}

Camara, Luiza Diniz de Oliveira; Romanel, Celso (orientador). Análise do Ciclo de Vida do Sistema de Carregamento de uma Frota de Veículos Elétricos - Geração e Armazenamento Local de Energia. Rio de Janeiro, 2015. 91p. Dissertação de Mestrado - Departamento de Engenharia Civil, Pontifícia Universidade Católica do Rio de Janeiro.

Atualmente, uma das principais metas do governo alemão é o desenvolvimento do mercado de veículos elétricos no país. Para tanto, o real potencial de redução de emissões atmosféricas através do uso de carros elétricos precisa ser analisado em detalhes. Para que o impacto ambiental causado por veículos elétricos seja minimizado faz-se necessário o uso de energias renováveis. Considerando-se a intermitência de tais fontes energéticas, baterias estacionárias podem ser utilizadas para aumentar a eficiência do sistema energético. Um método quantitativo se faz então necessário para determinar se o uso de energia renovável produzida em pequena escala, incluindo o sistema de armazenamento, é ambientalmente mais vantajoso quando comparado ao uso da energia fornecida pela rede elétrica Alemã. Essa análise quantitativa é possível através do método chamado análise de ciclo de vida (LCA, sigla em inglês). Esse estudo aborda o caso da concessionária de energia de Braunschweig, Alemanha, BS Energy, que pretende instalar um sistema fotovoltaico com uma bateria estacionária para o carregamento de sua frota de veículos elétricos. Para tanto, o presente trabalho tem como objetivo realizar uma análise do ciclo de vida do sistema de carregamento da frota de veículos elétricos da BS Energy para avaliar o real impacto ambiental provocado por tal sistema e fazer uma comparação com o impacto gerado pelo uso de energia proveniente da rede elétrica de Braunschweig. Para dar suporte ao trabalho será realizada uma revisão de literatura sobre o método análise de ciclo de vida, veículos elétricos, baterias de lítio e geração de energia solar. Baseado em informações disponíveis na literatura, bem como nos dados fornecidos pela BS Energy, é construído e calculado o fluxo do ciclo de vida do sistema em questão.

\section{Palavras-chave}

Veículos Elétricos; Energias Renováveis; Baterias; Análise do Ciclo de Vida. 


\section{Table of Contents}

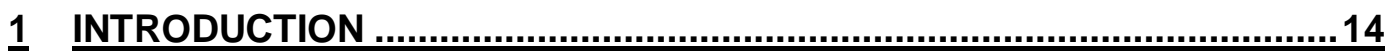

$\underline{2}$ LITERATURE REVIEW .............................................................17

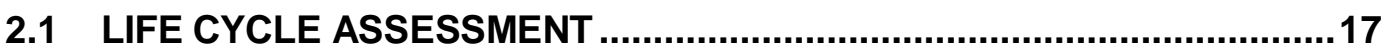

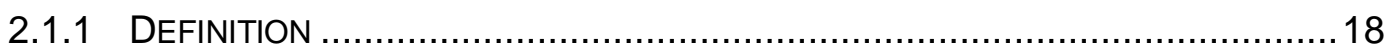

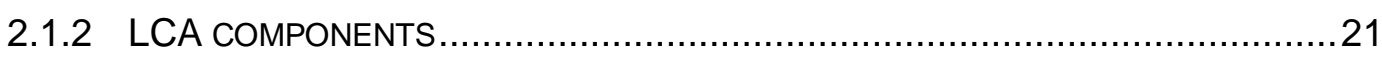

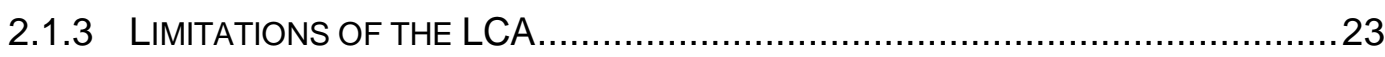

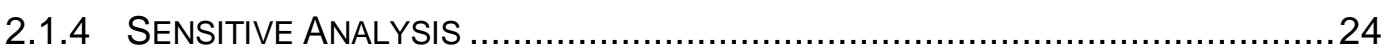

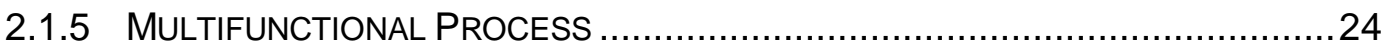

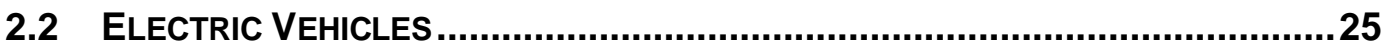

2.3 ELECTRICITY STORAGE / LITHIUM BATTERIES ............................................30

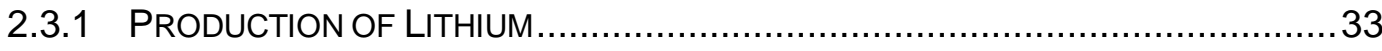

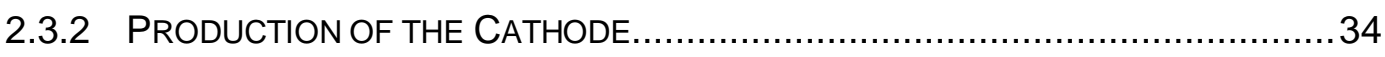

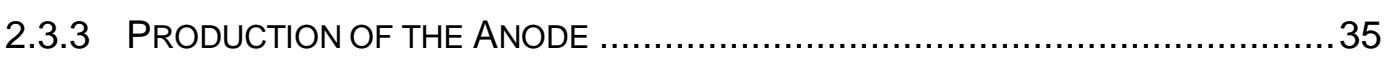

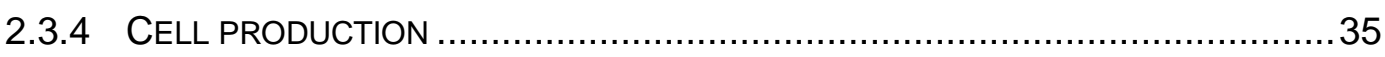

2.3.5 USE PHASE / EFFICIENCY AND LIFETIME.............................................. 37

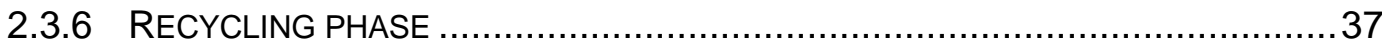

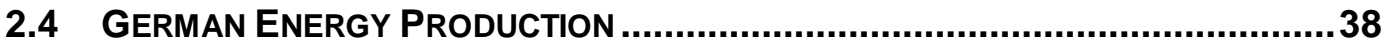

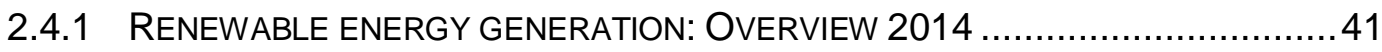

2.4.2 SOLAR POWER PRODUCTION POTENTIAL IN GERMANY - PHOTOVOLTAIC...... 42

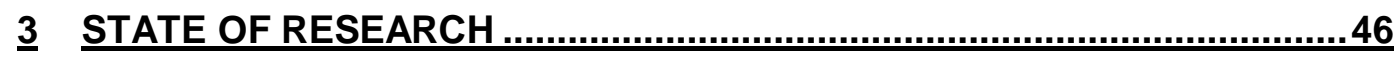

3.1 LCA OF PV ENERGY GENERATION...........................................................

3.2 LCA OF LITHIUM BATTERY.................................................................50

4 METHODOLOGICAL FRAMEWORK

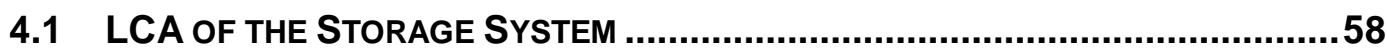

4.2 LCA SOLAR ENERGY GENERATION ....................................................60

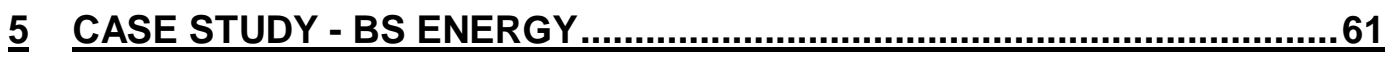

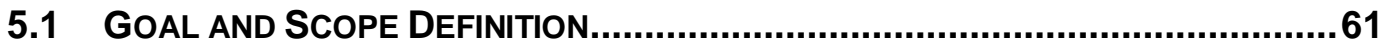

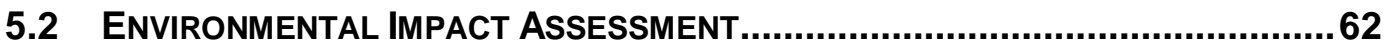


5.3 SCENARIO 1 - USE OF ENERGY FROM THE GRID .....................................63

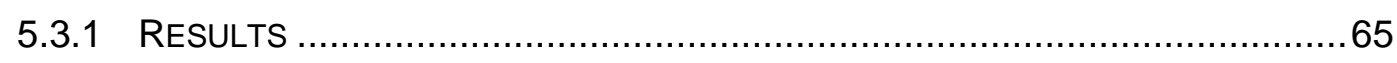

5.4 SCENARIOS 2 AND 3 - BS ENERGY SOLAR ENERGY GENERATION..................66

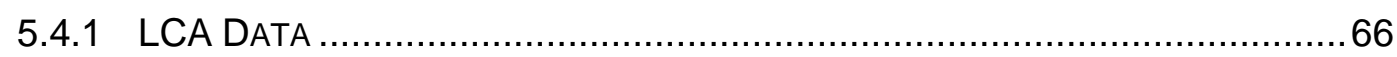

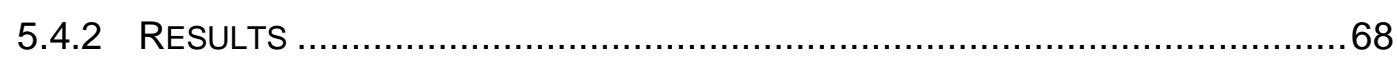

5.5 SCENARIOS 4, 5 AND 6 - STATIONARY BATTERY......................................70

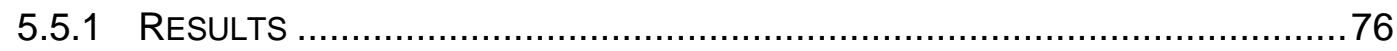

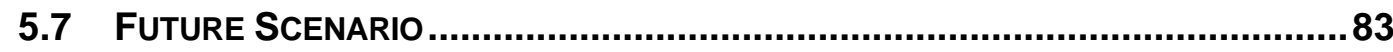

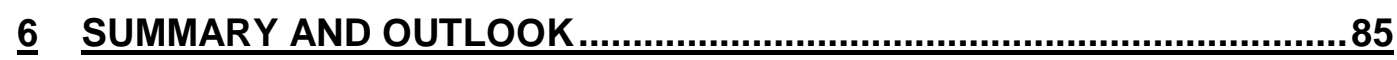

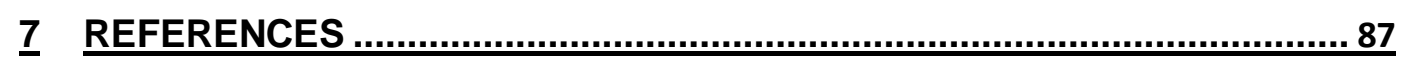




\section{List of figures}

Figure 2.1 - Life Cycle Assessment Framework ........................................20

Figure 2.2 - Basic structure of a unit process in terms of inputs and outputs .....21

Figure 2.3 - Scheme of the LCA framework, linking LCI results via the midpoint categories to endpoint categories 22

Figure 2.4 - Dey Griswold Electric Phaeton, 1986 ....................................26

Figure 2.5 - Comparison between combustion and e-car efficiency..................28

.

Figure 2.6 - Production chain of Li-ion batteries .......................................... 33

Figure 2.7 - Scheme of a battery production.................................................. 36

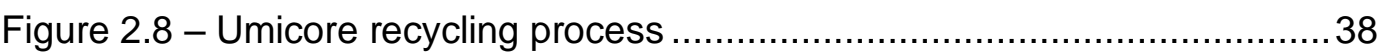

Figure 2.9 - Electricity generated during 2013 in TWh ....................................40

Figure 2.10 - Energy generated on the first eleven months of 2014 in TWh ......40

Figure 2.11 - Electricity export and import balance since 2001 .......................4 41

Figure 2.12- Average solar irradiation in Germany within a year period of time .43

Figure 2.13 - Complementarity between solar and wind energies ....................44

Figure 2.14 - Monthly production of Solar and Wind Energy ............................ 45

Figure 3.1 - Share of process stages for a Swiss grid-connected, 3kWp

slanted-roof installation with a multicrystalline silicon panel for

selected elementary flows of the inventory. CED = Cumulative Energy

Demand.

Figure 3.2 - Energy payback time of 3Kwp PV plants in Switzerland in relation

to the UCTE electricity mix.

Figure 3.3 - Average cradle-to-gate values per KG of battery and the

cradle-to-gate values per MWh of electricity output calculated in this study

Figure 3.4 Life cycle battery impacts showing the contributions from

cradle-to-gate and use stages of the batteries.

Figure 3.5 - CED impacts of the major processes during the cradle-to-gate

stage of Lithium lon battery life cycle.

Figure 3.6 - GWP impacts of the major processes during the cradle-to-gate stage of Lithium lon battery life cycle

Figure 3.7 - ReCiPe 2008 single point score for Lithium Ion

cradle-to-gate processes that adversely impact the environment

Figure 4.1 - Scheme of the system studied

Figure 4.2 - Relation between the impact of using the storage system and 


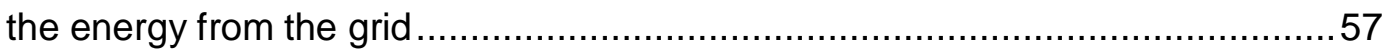

Figure 4.3 - Draft of the LCA model for the charging station ...........................58

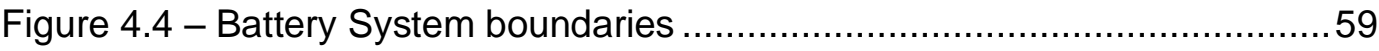

Figure 5.1 - Energy sources share in gross power production in $2014 \ldots \ldots \ldots . . .64$

Figure 5.2 - Renewables share in production gross power productionin 2014...66

Figure 5.3- Solar energy generated in by a $10 \mathrm{KWp}$ panel in Braunschweig

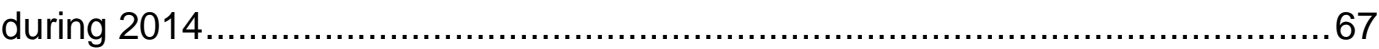

Figure 5.4 - Scheme of a cell of the stationary battery .................................. 72

Figure 5.5 - Structure of the recycling process of the battery........................... 75

Figure 5.6 - GWP of the 6 different scenarios (in $\mathrm{Kg} \mathrm{CO} 2-\mathrm{Eq}$ ) ..........................79

Figure 5.7 - Ozone depletion potential of the 6 different scenarios

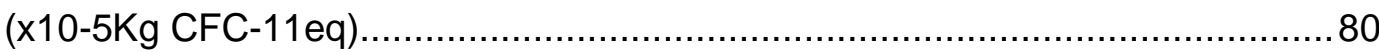

Figure 5.8 - Photochemical smog potential of the 6 different scenarios

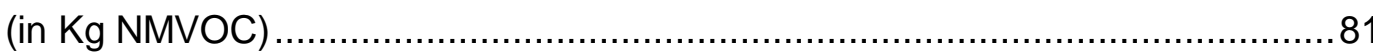

Figure 5.9 - Acidification potential of the 6 different scenarios (in $\mathrm{Kg} \mathrm{SO}$-Eq).. 82 Figure 5.10 - Marine eutrophication potential of the 6 different scenarios (in $\mathrm{Kg} \mathrm{N}$-Eq) 82

Figure 5.11 - Freshwater eutrophication potential (in Kg P-Eq) 83

Figure 5.12 - Scheme of vehicles end of chain emissions considering different energy sources .84 


\section{List of Tables}

Table 2.1 - Characteristics of battery electric vehicles and hybrid electric

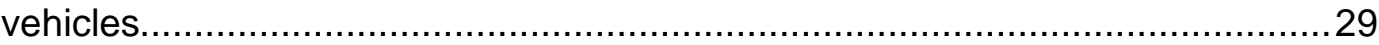

Table 2.2: Different Compositions of the Li-lon Batteries..................................32

Table 3.1 - Energy and environmental pay back time for PV and PV/T systems

Table 5.1 - Solar energy production from a 10,56KW PV System

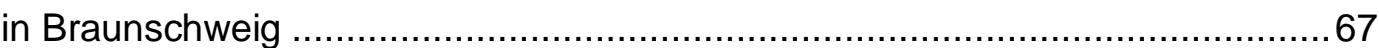

Table 5.2 - Comparison between different Li-ion batteries.............................71 


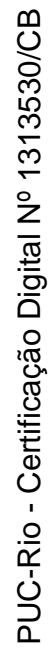

"In times of universal deceit - Telling the truth is a revolutionary act".

George Orwell, (1949) 


\section{INTRODUCTION}

In 2011, worldwide transportation accounted for $22 \%$ of global $\mathrm{CO} 2$ emissions, an increase rate of $2 \%$ per year since 2000 (IEA, 2014). In this regard, road transport is responsible for the largest share of this energy use, of around $21.11 \mathrm{TWh}$. Light-duty vehicles account for more than $40 \%$ of the total transport sector's energy demand, with freight transport accounting for $30 \%$, air and shipping $10 \%$, and buses and trains another $7 \%$.

According to the six emission scenarios drawn by the Intergovernmental Panel for Climate Change (IPCC), an increase on $\mathrm{CO}_{2}$ levels from 369 parts per million to between 540 and 970 parts per million is expected for the next century (Nakicenovic and Swart, 2000). This would represent an increase on global average temperatures between $1.4{ }^{\circ} \mathrm{C}$ and $5.8^{\circ} \mathrm{C}$ (Watson, 2001). The Fith Assessment Report from IPCC report affirm that the Earth temperature has already presented an increase of $0.85^{\circ} \mathrm{C}$ since the pre-industrial times due to green house gases (GHGs) emissions, where $78 \%$ of the total emissions increase occured between 1970 to 2010 is represented by CO2 emissions from fossil fuel combustion and industrial processes. Additionally, about half of the cumulative anthropogenic CO2 emissions between 1750 and 2010 have occurred in the last 40 years. Between 2000 and 2010, annual anthropogenic GHG emissions have increased by $10 \mathrm{GtCO} 2 \mathrm{eq}$, where energy supply was directly responsible for $47 \%$ of this increase, industry for $30 \%$, transport for $11 \%$, and the construction sector for $3 \%$.

This alarming emissions scenario led to the conclusion of the need for sustainable development, whose concept was presented by the Brundtland Report in 1987. In 1997 the Kyoto protocol was signed, establishing the target of 5.2\% CO2 emissions reduction between 2008 and 2012, considering the level of emissions from 1990. The protocol highlighted the transport sector as one of the key sectors to be tackled in order to achieve this goal, and since then, transport was featured heavily in the political agendas of the 38 developed countries that signed the agreement. 
As previously mentioned, road transport is the biggest producer of greenhouse gases in the transport sector, although the motorcar is not the only responsible for all these emissions. Public transportation also plays a significant role on emissions, but the major contributor is road freight, that typically accounts for just under half of the road transport total.

Both the public and private sector have been promoting different initiatives in order to reduce GHGs emissions all over the world. For companies, getting active about environmental issues is no longer a matter of values and beliefs; it has become a necessity, not only due to the stricter environmental policies but also for keeping their competitiveness on the market. As a result, electric vehicles have reemerged as a potential solution for reducing emissions, and the automotive industry started to make large investments on the production and improvement of electric vehicles, either fully electric or hybrid. Concerns about its efficiency and the increase of electricity demand, however, still hang over industry and governments. The World Business Council for Sustainable Development, for example, defends the idea that although advances in technology should eventually reduce fuel usage and emissions, these improvements will be offset in the nearterm by increased ownership and use (World Business Council for Sustainable Development, WBCSD, 2001). In this regard, Life Cycle Assessment (LCA) studies contribute on the understanding of what are the real impacts of using electric vehicles, also considering the impact of the energy necessary for their charge, and the storage system that may be needed.

This work is a LCA that was developed to support the Braunschweiger Versorgungs-AG \& Co. KG (BS Energy) on the decision of whether to buy a stationary battery to store its photovoltaic energy generation, used for charging five of their electric vehicles. The main idea is to determine whether it is environmentally worthy having the stationary battery, considering that the vehicles can be charged straight from the photovoltaic system and from the German electricity net. Thus, the general objective of the present work is to determine how efficient and environmentally friendly is the storage system used by BS Energy for its electrical vehicles, in comparison with the usage of the grid energy.

This thesis is divided as follows. In Chapter 2 a literature review of the main topics involved on the work is presented, namely: Life cycle assessment 
definition, the current scenario for the energy generation in Germany, overview of the electrical vehicles market and an introduction on energy storage systems. This chapter intends to present an overview of the concepts being considered on the present study, and technologies that are currently being used or developed.

In Chapter 3 the current state of research is presented, with a brief analyses of what has already been developed regarding the life cycle assessment of electrical vehicles fleets with local energy storage systems. The main objective of this section is to have a parameter for comparison with the results obtained in this work.

In Chapter 4 the methodological framework is described, and the parameters used on the model are defined, to situate the reader on the steps that will be taken in order to obtain consistent results.

In Chapter 5 the case study of BS Energy is introduced and analyzed. The goal on this chapter is to verify the environmental viability of having a stationary battery that stores local renewable energy production.

Finally, Chapter 6 contains the conclusions and suggestions. The goal of this chapter is to summarize the results from the LCA, providing the information necessary to support the decision of whether to use the storage system. Suggestions regarding better solutions for the case study are also presented. 


\section{LITERATURE REVIEW}

This chapter presents a literature review of the topics that serve as basis for this work, namely:

- Life Cycle Assessment;

- Electric Vehicles;

- Electricity Storage and Lithium Ion Batteries; and

- German energy production.

The Life Cycle Assessment section intends to clarify the meaning and applications of this technique, which is being increasingly introduced, not only on industrial processes but also as a base for decision making of business owners and governmental entities.

On the section about electric vehicles it is presented a brief historical overview on this technology. The idea is to give an overview of its development, and clarify the reasons for its reintroduction on the market. Furthermore, the different types of vehicles that are currently being produced are briefly explained.

The section on electricity storage and lithium ion batteries gives an overview of the composition and production of Li-ion batteries. Knowing the battery components and its production chain is important for understanding the environmental impact caused throughout the battery life cycle, and also to enable the identification of better solutions.

Lastly, this chapter presents a brief research on the German electricity production with the intention of giving an overview on the German electricity net. This includes annual energy production, energy demand, the share of renewable energy on the electricity net, and how is it being developed.

\subsection{LIFE CYCLE ASSESSMENT}

Due to increasing concerns about the impact of anthropogenic activities on the environment, world decision makers and society started to demand more integrated information on industrial processes and services in general. Therefore, 
the environmental impact assessment field has become an important area. Among others, one popular tool in this field is the Life Cycle Assessment (LCA) (Finnveden et al., 2009), which is considered to be one of the best choices for product related assessments, since it takes into account the interactions between the product and the environment over the complete life cycle of the product value chain (Ness et al. 2007).

Industrial processes are typically evaluated based on indicators, and the identification of the most relevant indicators for each process should consider the whole life cycle of the product, as well as its supply chain. In this regard, LCA is of great relevance to help companies on the evaluation of the environmental impacts of its products.

The ISO 14000 series was created in the beginning of the 1990 decade to meet this growing demand for a more environmental friendly economy. It provides a unified technical framework for carrying out LCA studies. Since its release, several LCA studies have been published, and the LCA methodology has developed and matured.

The concepts that served as base for the LCA have first emerged in the 1960s (Baumann et al., 2004). Until the early 1990s, studies that aimed at an assessment of a material, energy and waste flows of a product's life cycle would receive different names, such as: resource and environmental profile analysis (REPA), ecobalance, integral environmental analyses, and environmental profiles.

In what follow there will be a brief introduction on the Norm ISO 14040, which defines and specifies the Life Cycle Assessment (LCA) technique, presenting the definition, main phases and limitations of an LCA. Furthermore, a brief introduction on sensitive analyses and multifunctional processes is given, in order to clarify all the important topics for the methodology of the present research.

\subsubsection{Definition}

Life Cycle Assessment (LCA) is an environmental management technique that has its basic principles standardized by the International Organization for Standardization (ISO), more specifically by ISO 14040, and is defined as the 
"compilation and evaluation of the inputs, outputs and potential environmental impacts of a product system throughout its life cycle" (ISO 14040).

The basic idea of LCA is that all the steps involving a production system must be analyzed making sure that all the environmental burdens are assessed and enabling the support to the decision-making. Therefore, it is a tool for the analysis of the environmental impacts of a product or service system. That means the impacts at all stages of their life cycle, since the extraction of raw material, through its production, use and final destination, 'from the cradle to the grave'. A cradle-to-grave analysis involves a 'holistic' approach, bringing the environmental impacts into one consistent framework (Guineé et al., 2004).

As shown in figure 2.1, an LCA consists of four steps. The first one is the goal and scope definition, which describes the underlying questions, the system boundaries and the definition of a functional unit for the comparison of different alternatives. The second step is the inventory analysis, where flows of pollutants, materials and resources are investigated and recorded. On the third step, the impact assessment, the elementary flows (emissions and resource consumption) are described, characterized and aggregated for different environmental problems. On the interpretation phase, the results of the Life cycle inventory (LCI) or Life Cycle Impact Assessment (LCIA), are discussed and final conclusions are drawn. These conclusions serve as grounds for decision-making recommendations.

When the goals of the LCA are fulfilled just with the inventory analysis phase and its interpretation, it can be referred as a Life Cycle Inventory (LCI) study. The LCI is, therefore, an LCA without the LCIA phase. A LCA typically aims to analyze and compare different products, processes or services that fulfill the same utility (e.g., photovoltaic against nuclear power), helping to demystify some simplistic notions by calculating the environmental impact of a product or service system. 


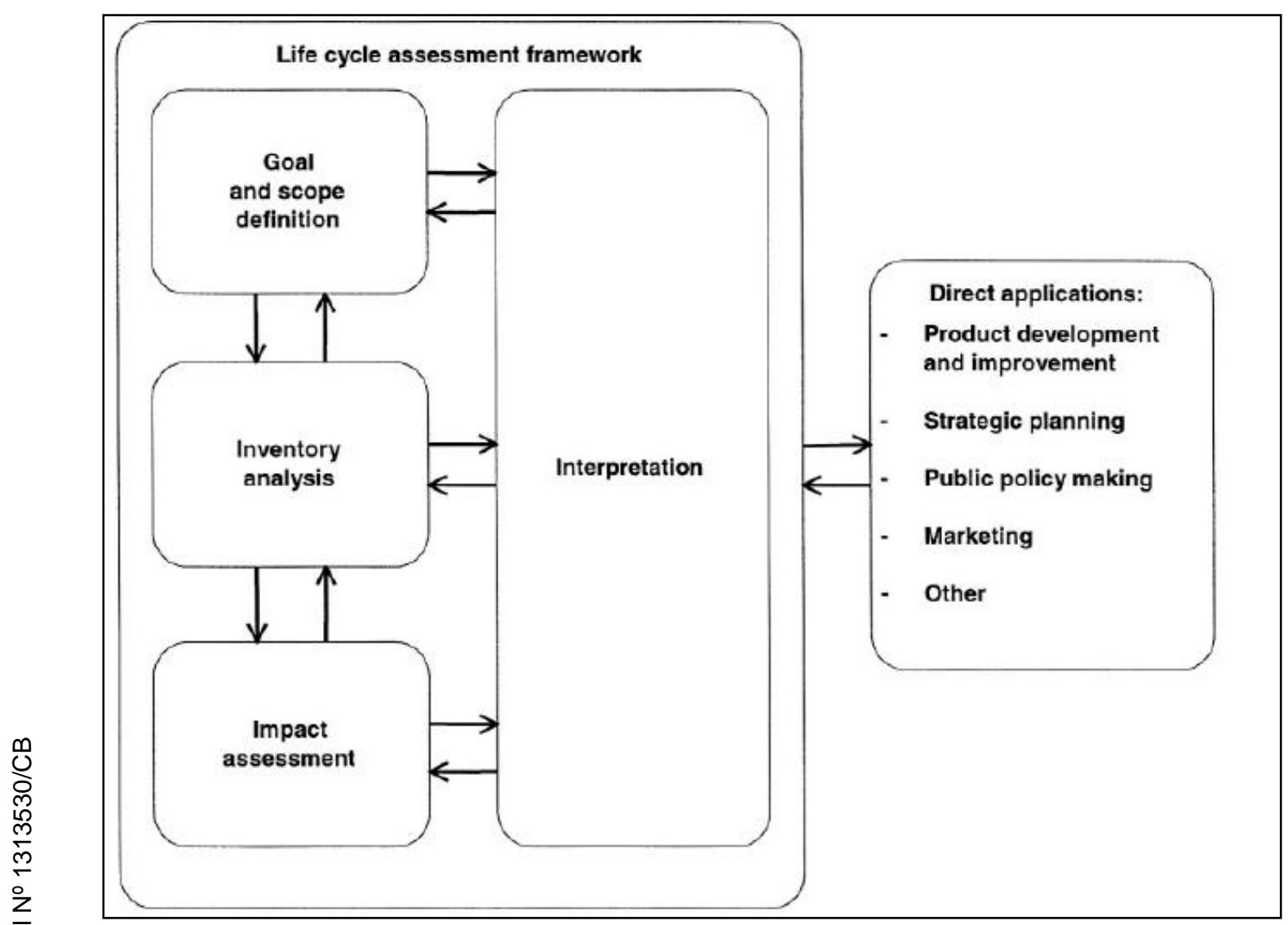

Figure 2.1 - Life Cycle Assessment Framework

Source: ISO 14040.

LCA can be used for several different purposes, such as in the following examples (Guineé et al., 2004):

- An Industry choice of one-way packaging procedure.

- Comparison between different types of waste management by a municipality, or the development of a waste management strategy.

- Assessment of the environmental benefits of different types of biomass use (including thinning wood), for instance in the production of electricity or paper.

- Comparison between different means of freight transport (road, rail, water) as basis for public investment in new infrastructure.

- Development of greener buildings. This can be already observed in many countries. In the Netherlands, for example, new houses must meet 
minimum environmental requirements. This includes not only the reduction of energy consumption, but also of the environmental impacts imposed by raw material use and the construction process.

The examples above cited are only part of the wide comprehensiveness of LCA application. Nowadays a convergence between the requirements of LCA in product policy and wider applications is also observed in eco-design. In Germany LCA is being used mainly in the design of new cars and other areas of the automotive industry.

\subsubsection{LCA components}

In a LCA "the sum of the allocated inputs and outputs of a unit process shall equal the unallocated inputs and outputs of the unit process", as shown in Figure 2.2 (International Organization for Standardization (ISO) 1998).

\begin{tabular}{|c|c|c|}
\hline Inputs & & Outputs \\
\hline $\begin{array}{l}\text { Economic flows: } \\
\text { Goods, Services, } \\
\text { Materials, Energy, etc. }\end{array}$ & \multirow{2}{*}{ Unit Process } & $\begin{array}{l}\text { Economic flows: } \\
\text { Goods, Services, } \\
\text { Materials, Energy, waste, etc. }\end{array}$ \\
\hline $\begin{array}{l}\text { Environmental Interventions: } \\
\text { Resources, } \\
\text { Land Transformation, etc. }\end{array}$ & & $\begin{array}{l}\text { Environmental Interventions: } \\
\text { emissions to air, chemicals, } \\
\text { Sound, waste, etc. }\end{array}$ \\
\hline
\end{tabular}

Figure 2.2 - Basic structure of a unit process in terms of inputs and outputs Source: Gaines and Dunn, 2014.

Therefore, a life cycle assessment is a compilation and evaluation of the inputs and outputs and the potential environmental impacts of a product system throughout its life cycle (ISO 14040). The product system consists of a certain number of processes that together enable the delivery of a specific product, which in turn is defined by its functional performance (functional unit), and can be a good or service. Hence, LCA data refers primarily to these "inputs and outputs". 
As previously mentioned, in the impact assessment phase, the LCI results or indicators of environmental interventions are translated into environmental impacts, which may be assessed at the midpoint or endpoint level. Midpoint indicators are considered to be links in the cause-effect chain of an impact category, used to measure a substance's potency of effect. Endpoint indicators, on the other hand, reflect the relative importance of emissions or extractions. Examples of midpoint and endpoint indicators are shown in Figure 2.3.

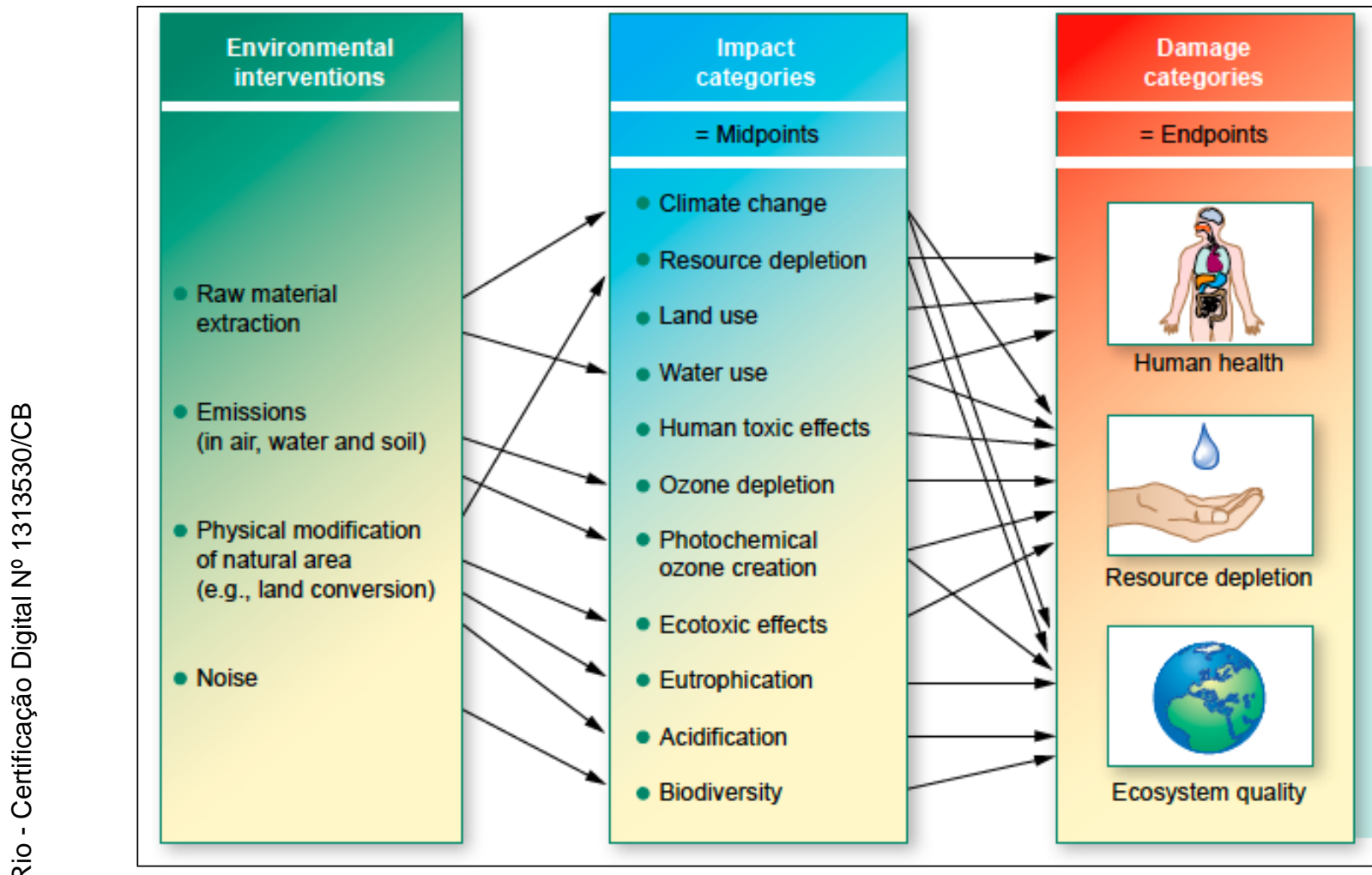

Figure 2.3 - Scheme of the LCA framework, linking LCI results via the midpoint categories to endpoint categories

Source: UNEP/SETAC, 2011.

From the midpoint indicators, also called impact categories, mentioned in Figure 2.3, five can be considered of higher importance for most studies. The ISO 14040 recommends the calculation of the impact categories described bellow:

- Global warming: the global warming potential relates to the potential of contributing to climate change. The measurement of such potential is made in $\mathrm{Kg} \mathrm{CO}_{2} \mathrm{eq}$; 
- Ozone depletion: ozone depletion potential concerns the potential of depleting the ozone layer, mostly by CFCs emission. This potential is measured in kg CFC-11-Eq;

- Photochemical smog: also known as photochemical oxidant formation or summer smog, it is mainly caused by solar radiation reaction with air pollutants, mostly emissions from fossil fuel combustion. It is harmful both for human health and for material goods, causing breath problems, eye irritation and damage to some materials;

- Acidification: the acidification potential increases with the increase of sulphur $(\mathrm{S})$ and nitrogen $(\mathrm{N})$ in the soil and is calculated in $\mathrm{SO}_{2} \mathrm{eq}$;

- Eutrophication: the ecosystem (in this case the marine and freshwater ecosystem) response to the increase of nutrients, mainly nitrogen and/or phosphates, due to human activities, such as the use of fertilizers and the disposal of sewage on water. This leads to an increase of certain organisms, such as phytoplankton, in the ecosystem. The marine eutrophication potential is calculated in $\mathrm{Kg} \mathrm{N}-\mathrm{Eq}$ and the freshwater eutrophication potential in $\mathrm{Kg} \mathrm{P}-\mathrm{Eq}$.

Considering so many different impact categories in one study may have a few disadvantages, since most of times one technical solution can be better for mitigating one environmental problem but not another. It is hard to find the ideal solution for all of them. And, assuming that not all of them will be mitigated it is not always easy to decide which one should be valued the most.

\subsubsection{Limitations of the LCA}

Despite its maturity, the LCA tool still needs improvements. Some Sutudies have pointed many issues on the current LCA methodology, such as spatial variation, allocation issues, local environmental uniqueness, boundary conditions, among others.

Gaines and Dunn (2014) point the holistic nature of the LCA as a major strength but also as a limitation. The reason is that to analyze the complete life 
cycle of a product the simplification of some aspects is needed. Another limitation is that LCA cannot address localized impacts. The time aspect can be also seen as a limitation, once LCA is typically not a dynamic approach, but a steady state (Gaines and Dunn, 2014).

In LCA the main focus are physical characteristics and economical aspects of an industrial process. Market aspects or technological improvements are not considered. That means that all processes are viewed as being linear. Therefore, LCA involves technical assumptions and value choices.

Lastly, it is important to notice that LCA provides information to support a decision, which means that it can't be used as a substitute for the decision making process. Thus, a decision can be based on LCA studies and other evidences, but the LCA by itself can't prove that the decision should be made.

\subsubsection{Sensitive Analysis}

Sensitive analysis is defined by ISO 14040 as: "systematic procedures for estimating the effects of the choices made regarding methods and data on the outcome of a study".

A sensitive parameter is a parameter which can considerably influence the result if changed. Thereby, a sensitivity analysis helps on the identification of parameters that should be accurately known, or on the identification of parameters (non-sensitive) that can be fixed in order to simplify the model (Saltelli et al. 2008).

\subsubsection{Multifunctional Process}

An LCA usually aims to analyze and compare different products, processes or services that fulfill the same utility (e.g. photovoltaics against nuclear power). This kind of analysis is known as a multifunctional process analysis. One example of a multi-output process is the solar energy generation, where it can be produced heat or electricity.

One of the most used databases for LCI analyzes of multi-output processes, such as the solar energy generation, is the Ecoinvent database, which is 
a life cycle inventory database for energy systems, materials, transports and chemicals, from the Swiss Center for Life Cycle Inventories. The use of this database for multi-output processes has several advantages, such as: the fact that all allocation factors are reported, making the process fully transparent, the LCIs of all co-products in the database are fully consistent, and finally, allocation factors may be changed and LCI results can be recalculated.

\subsection{Electric Vehicles}

Contemporary society has been increasingly dependent on road transportation, which has created a dependency on fossil fuels. Light-duty vehicles have been responsible for $10 \%$ of the global energy demand as well as green house gas emissions (Solomon et al. 2007). Furthermore, according to a study carried out in 2004 by the World Business Council for Sustainable development, the ownership of light-duty vehicles should increase by $185 \%$ over the period 2000-2050, reaching 2 billion light-duty vehicles on the roads worldwide. Considering that these vehicles would all be fed by fossil fuel, this would represent a substantial increase of many impact categories, such as global warming potential, eutrophication potential, ozone depletion, resource depletion and human toxicity, among others.

To deal with this situation, electric vehicles (EV) have emerged as a cleaner alternative to regular combustion engine vehicles. Different from what many believe, the electric vehicle is not a recent development, it has actually been around for over one hundred years. The first models were developed in France and England in the late 1800s, and the first commercial version was established in 1897 in the United States, as a fleet of taxis for the New York City (Idaho National Laboratory, 2014).

The early electric cars looked like a horseless carriage with an approximate range of $29 \mathrm{Km}$ and a speed of $22 \mathrm{Km} / \mathrm{h}$. One example is the 1896 Dey-Griswold Electric Phaeton, shown in Figure 2.4. 


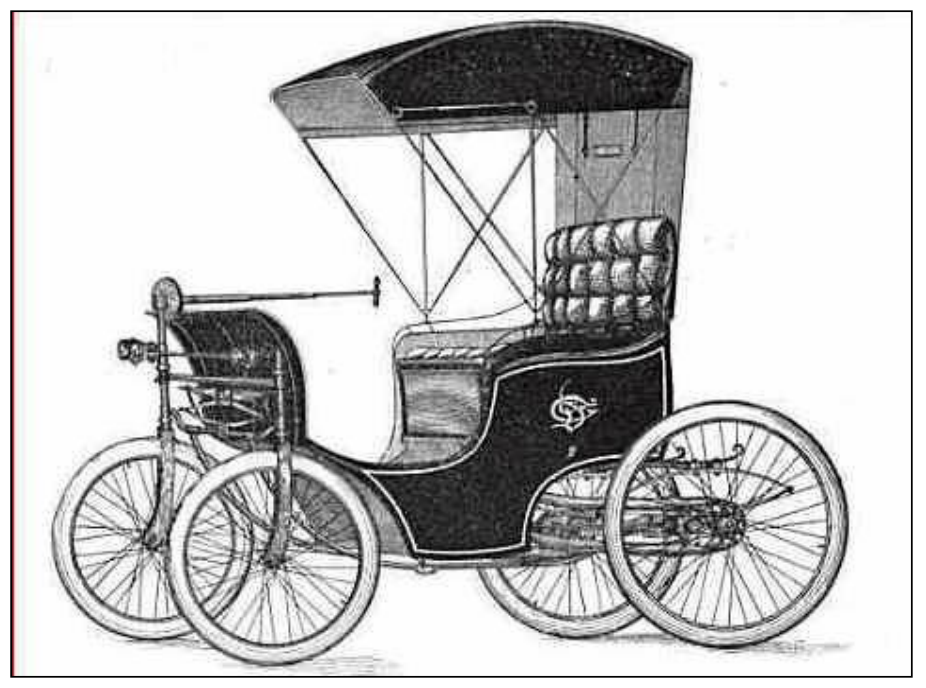

Figure 2.4 - Dey Griswold Electric Phaeton, 1986.

Source: Popular Science Magazine, Fev. 1949.

Electric vehicles had a cost range of US\$1.000 - US\$3.000. They presented many advantages when compared to gasoline cars, such as not having vibration, noise, gasoline smell and gears. Therefore the electric vehicles were preferred than gasoline cars, and reached its peak production in 1912.

The decline of electric cars started in the 1920s, with the need for longerrange vehicles, low prices of crude oil, the invention of the electric starter and the initiation of mass production of combustion engines by Henry Ford, bringing the gasoline vehicles prices down, to $\$ 500$ - $\$ 1.000$. Electric vehicles have then disappeared until the 1960s, when the need for reducing emissions and the dependency on imported crude oil emerged. A bigger effort on the development of electric cars began in the 1990s, when the concept of sustainable development emerged and several legislative and regulatory actions to support the development of electric vehicles were created.

This technology is still being improved in order to achieve better performance and to develop more efficient batteries with lower environmental impact. Electric vehicles have received many incentives from different countries, such as the United States (US) and the European Union (EU) as a whole in order to be introduced on the market. In 2009, a consortium between the International Energy Agency and eight other countries, namely France, Germany, China, Japan, 
South Africa, Sweden, Spain and the US, set the target of reaching 20 million EVs on the streets by 2020 .

However, there are still a few concerns related to this type of vehicles. One of the biggest concerns is the increase of energy demand. Considering that the renewable energy market is still not big enough to meet a growth in demand, the greenhouse gas emissions may remain very high. Another important concern is related to vehicles batteries: the metals required for their production are nonrenewable resources, and their extraction and production is very energy intensive.

Conventional cars with internal combustion engines are extremely inefficient, with between 70 to $86 \%$ of the fuel energy lost through wasted heat (U.S Department of Energy, 2014). The several decades of cheap oil has led to a disincentive on the improvement of more energy efficient cars. However, the increase of oil prices in recent years combined with emissions policies have driven car manufacturers to focus on engine efficiency and on the improvement of electric cars.

Even with battery issues, electric cars present much higher energy efficiency when compared to combustion vehicles, even accounting for all stages of energy conversion. Generally speaking, the efficiency of a system is measured by the conversion rate between inputs and outputs of the system. The Figure 2.5, illustrates a comparison between the combustion and electric car efficiency, based on the average currently used technology for both electric and combustion vehicles. 


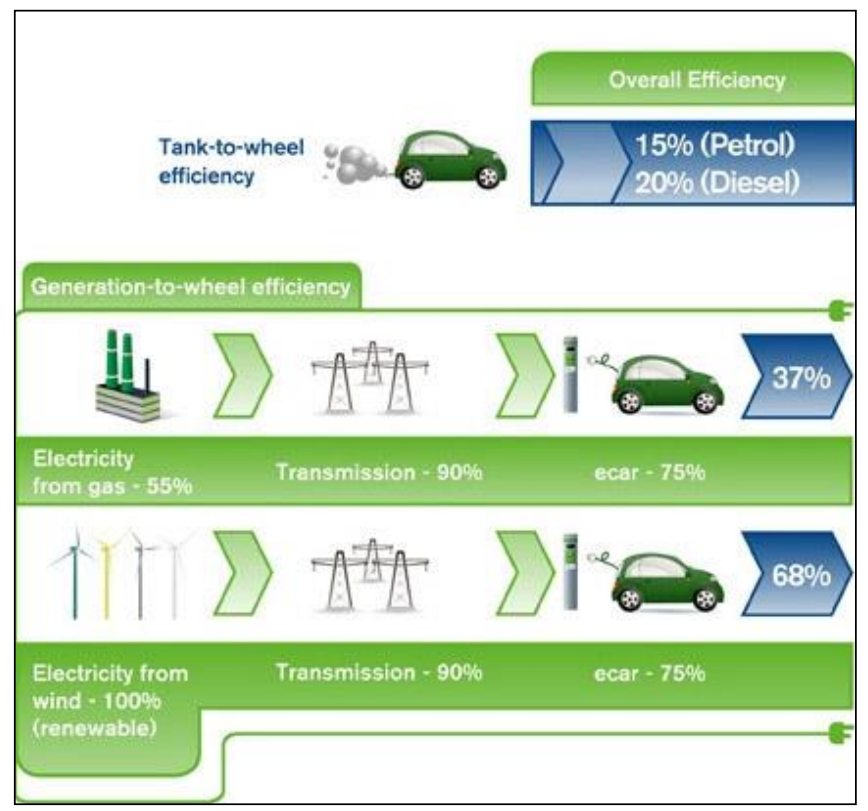

Figure 2.5 - Comparison between combustion and e-car efficiency

Source: ESB ecars, 2014.

There are four main types of electric vehicles: plug-in hybrid, hybrid, extended range, and battery electric vehicle. The plug-in hybrid technology is a dual fuel car that can take energy form either the electric motor or the combustion engine; it has a larger battery that is charged by the grid in order to increase fuel efficiency. The electric power on plug-in hybrid can run about $64 \mathrm{Km} / \mathrm{h}$ without the combustion engine. The battery in this case can be charged by the gas engine, regenerative braking and by plugging the vehicle (Tennessee Valley Authority, 2015).

The hybrid electric vehicle is also dual fuel, and the electric motor can also run 40mph (depending on the vehicle type). The difference is that instead of a big battery that works for both motors, there is a smaller battery only for the electric motor that increases fuel efficiency and is recharged by the gas engine and regenerative braking.

The extended range electric vehicle has an intern combustion engines to charge the battery, and only the electric motor can power the car. The combustion engine provides power to a generator that, for its turn, charges the battery. Finally, the battery electric vehicle is fully electric, which means that is has no combustion engine. This type of car must be plugged in to the electricity grid. 
Therefore, this type of vehicle requires larger batteries to accommodate the same travel range (Tennessee Valley Authority, 2015).

When compared to conventional vehicles, hybrid electric vehicles (HEVs) are more fuel efficient due to the optimization of the engine operation and recovery of kinetic energy during braking. The main concerns regarding this technology include increased cost, due to the introduction of motors, energy storage system, and power converters; safety, due to the introduction of high voltage in the vehicle system; and electromagnetic interference, caused by highfrequency high-current switching in the electric powertrain system, see Table 2.1 (C. C. Chan, 2007).

Table 2.1 - Characteristics of battery electric vehicles and hybrid electric vehicles

\begin{tabular}{|c|c|c|}
\hline $\begin{array}{c}\text { Type of Electric } \\
\text { Vehicle (EV) }\end{array}$ & Battery Evs & Hybrid Evs \\
\hline Propulsion & Electric motor drives & $\begin{array}{l}\text { Electric motor drives; } \\
\text { internal combustion } \\
\text { engines }\end{array}$ \\
\hline Energy System & Battery; ultracapacitor & $\begin{array}{l}\text { Battery; } \\
\text { ultracapacitor; } \\
\text { internal combustion } \\
\text { engine generating } \\
\text { unit }\end{array}$ \\
\hline $\begin{array}{l}\text { Energy Source and } \\
\text { Infrastructure }\end{array}$ & $\begin{array}{l}\text { Electric grid charging } \\
\text { facilities }\end{array}$ & $\begin{array}{l}\text { Gasoline stations; } \\
\text { electric grid charging } \\
\text { facilities (for plug-in } \\
\text { hybrid) }\end{array}$ \\
\hline Characteristics & $\begin{array}{l}\text { Zero emission; high } \\
\text { efficiency; } \\
\text { independence of crude } \\
\text { oils; relatively short } \\
\text { range; high initial cost }\end{array}$ & $\begin{array}{l}\text { very low emission; } \\
\text { higher fuel economy; } \\
\text { long driving range; } \\
\text { dependence on } \\
\text { crude oil; higher cost } \\
\text { compared with } \\
\text { internal combustion } \\
\text { engine vehicles; }\end{array}$ \\
\hline Major Issues & $\begin{array}{l}\text { Battery and battery } \\
\text { management; charging } \\
\text { facilities, costs }\end{array}$ & $\begin{array}{l}\text { Multiple energy } \\
\text { sources control, } \\
\text { optimization and } \\
\text { management; battery } \\
\text { sizing and } \\
\text { management }\end{array}$ \\
\hline
\end{tabular}

Source: C. C. Chan, 2007

The biggest challenges when it comes to electric vehicles are related to the cost and performance of their components, among which the battery deserves special attention. Depending on the size and technology of the battery, issues such as safety and reliability remain. 


\subsection{Electricity Storage / Lithium Batteries}

The intermittent renewable energy sources, decentralization of power generation, more stringent environmental regulations, among other factors, have lead to an increase of Electrical Energy Storage (EES) in recent years. The energy sector is becoming more complex, which has created a big market for EES. Further, many governments, such as, some European countries, USA and Japan, already have national programs to support the development of EES (Chen et al. 2009).

Electricity storage technologies in general play an important role in facilitating more secure, efficient and sustainable energy sources and forms of energy use (Naish et al., 2008). In the European power system, for example, they helped on the increase of the market share of renewable energy and distributed energy generation (European Commission, 2012a).

Electricity storage can also help on the achievement of more sustainable forms of goods production, energy use and mobility. When used for partially and/or fully electrified vehicles it allows a reduction in energy consumption and carbon dioxide emissions, and represents a storage option for energy generated during off-peak periods by photovoltaic systems and wind turbines (Sullivan and Gaines, 2010).

Therefore, the role of EES in stationary applications has been increasing in the electricity market. In order to make sure that the whole electricity chain is environmentally friendly, just having a high share of renewable energy is no longer enough, the technologies that emerge to support the electricity market, such as the storage system, must also be environmentally friendly. For this reason, it is essential to carry out environmental assessment for battery technologies.

The Li-ion battery, which is already a well-established technology for portable electronics, has begun to gain the market for large-scale applications. Many studies have shown that when compared to other technologies, Li-ion batteries have a superior specific energy and cycle life and no memory effect (lost of maximum energy capacity after the battery is charged several times without being completely discharge). They are mostly used in electronic products, such as cell phones, hearing aids, computers, and the like. However, they have been 
increasingly considered a good choice for bigger proposes, such as for the automotive industry, aerospace, and for electricity storage.

As it will be seen on chapter 3, chemistry differences in the cathode, anode, and electrolyte influence cell performance, as does packaging geometry. The cathode chemistry is the factor most commonly altered from cell manufacturer to cell manufacturer with terms like LFP, NCM, NCA, Cobalt, and Manganese reflecting the cathode chemistry class. Over $90 \%$ of lithium-ion anodes are comprised of graphite; silicon and titanium based materials are occasionally used to get better life and power performance in exchange for significantly higher cost.

The following Table (Table 2.2) shows the different components and constituent materials that can be used in Li-ion batteries to form different cathodes and anodes (Gaines and Nelson, 2009).

The composition of Li-ion batteries can be quite variable, depending primarily on the composition of the cathode. The battery capacity is directly related to the percentage by weight of electrode materials. In other words, as the amount of cathode and anode increase, the battery capacity also increases,. This occurs because battery operation is a result of chemical reactions, and the more material the bigger the chemical interaction. 
Table 2.2: Different Compositions of the Li-lon Batteries

\begin{tabular}{|c|c|c|}
\hline \multicolumn{3}{|c|}{ Composition of Lithium-Ion Batteries } \\
\hline Component & Materials & \begin{tabular}{|l} 
Percentage \\
\end{tabular} \\
\hline Cathodes & & $15-27$ \\
\hline & $\mathrm{Li}_{2} \mathrm{CO}_{3}$ & \\
\hline & $\mathrm{LiCoO}_{2}$ & \\
\hline & $\mathrm{LiMn}_{2} \mathrm{O}_{4}$ & \\
\hline & $\mathrm{LiNiO}_{2}$ & \\
\hline & $\mathrm{LiFePO}_{4}$ & \\
\hline & $\mathrm{LiCo}_{1 / 3} \mathrm{Ni}_{1 / 3} \mathrm{Mn}_{1 / 3} \mathrm{O}_{2}$ & \\
\hline & $\mathrm{LiNi}_{0.8} \mathrm{Co}_{0.15} \mathrm{Al}_{0.05} \mathrm{O}_{2}$ & \\
\hline Anodes & & $10 \_18$ \\
\hline & Graphite $\left(\mathrm{LiC}_{6}\right)$ & \\
\hline & $\mathrm{L}_{\mathrm{i} 4} \mathrm{Ti}_{5} \mathrm{O}_{12}$ & \\
\hline Electrolite & & 10_16 \\
\hline & Ethylene Carbonate & \\
\hline & Diethyl Carbonate & \\
\hline & $\mathrm{LiPF}_{6}$ & \\
\hline & $\mathrm{LiBF}_{4}$ & \\
\hline & $\mathrm{LiClO}_{4}$ & \\
\hline Separator & Polypropylene & $3 \_5$ \\
\hline Case & Steel & 40 \\
\hline
\end{tabular}

Source: Gaines and Nelson, 2009.

Generally, in the production chain of Li-ion batteries (Figure 2.6), the structural elements (cathode, anode, electrolyte and separator) contribute to almost $50 \%$ of the energy consumed. The production of the cathode represents $10-14 \%$ of the energy consumed, the production of the electrolyte $9 \%-13 \%$ and the battery assembly $6 \%$. Therefore, the amount of energy embodied in the structural materials is a very relevant to a battery LCA study.

Another important point to be mentioned is that, independently from the kind of Lithium-based cathode used to produce the electrode, the Lithium cathode (e.g. LiMn2O4, LiCoO2, LiFePO4 and lithium-nickel-manganese-cobalt) is necessarily made out of $\mathrm{LiCO} 3$ that, in the case of LiMn2O4-based cathode, represents around 16\%-35\% (after mining, milling, heating, etc). Thus, it is not so simple to determine the influence of different cathode materials regard the environmental impact (Gaines and Dunn, 2014). 


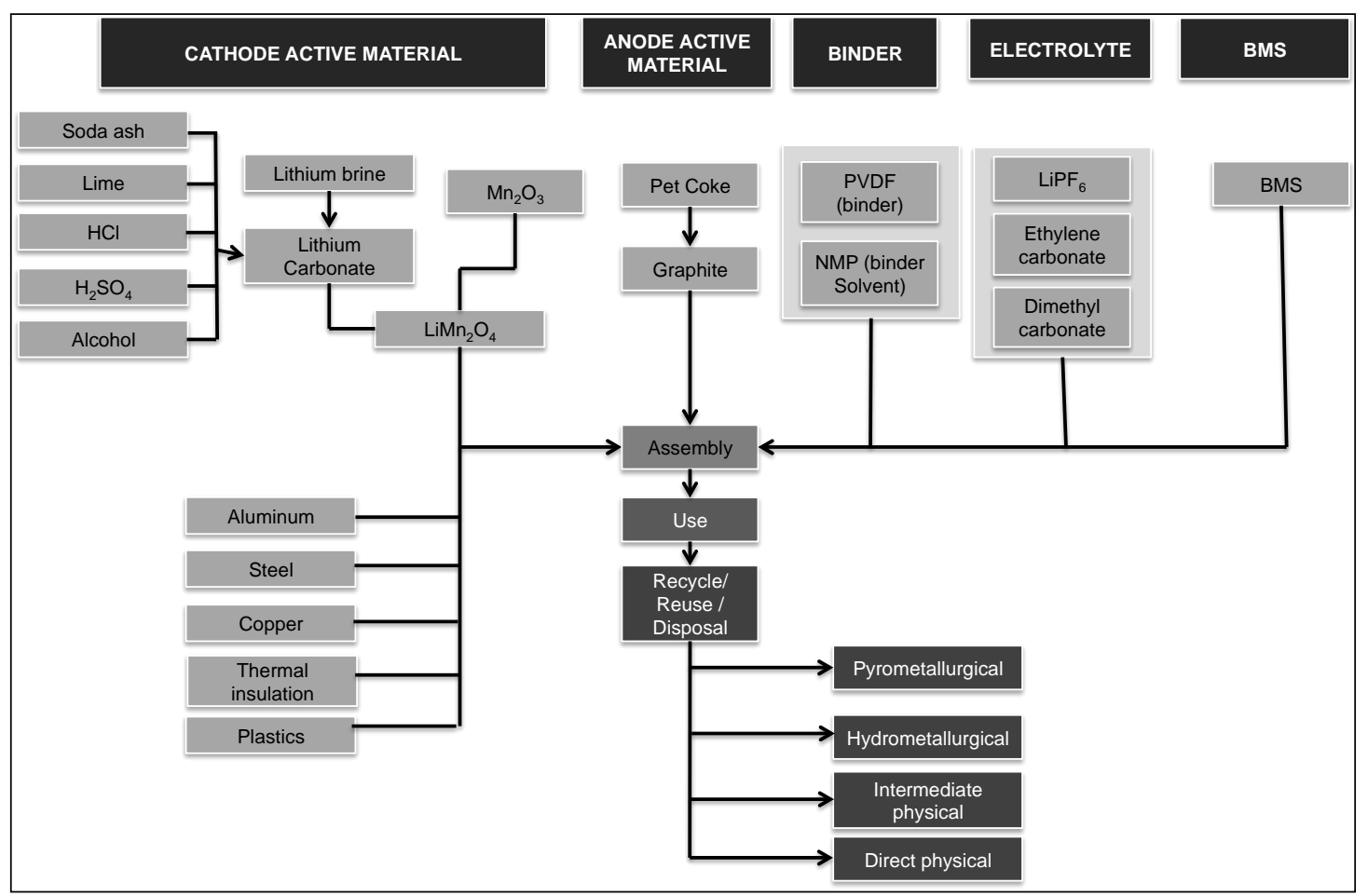

Figure 2.6 - Production chain of Li-ion batteries

Source: Gaines and Dunn, 2014.

With respect to the anode, the currently most used is the graphite, which also features a very energy intensive production process. Recently, lithium titanate $\left(\mathrm{Li}_{4} \mathrm{Ti}_{5} \mathrm{O}_{12}\right)$ has been gaining space in the battery industry as a high-power alternative anode material for $\mathrm{Li}$-ion cells. Its production occurs by reacting lithium carbonate $\left(\mathrm{Li}_{2} \mathrm{CO}_{3}\right)$ and titanium $\left(\mathrm{TiO}_{2}\right)$ at $850^{\circ} \mathrm{C}$ under air, and this procedure usually requires less energy than graphite production. The lithium titanate anode characteristics will be detailed on chapter 5 .

In the following section, in order to give an overview of energy and materials flow, more details on the production of each Li-ion battery component is given, making it easier to understand its advantages and disadvantages, as well as its environmental impacts (which will be detailed on chapters 3 and 5).

\subsubsection{Production of Lithium}

Lithium can be extracted from two different resources: brine-lakes, or saltpan deposits, and spodumenes. The salt-pan deposits are the more viable lithium 
sources, both energetically and economically. In this case, the extraction process happens as follows: first, brines are pumped from underground brine wells or lakebeds and brought into a solar evaporation pond that allows their concentration. After sufficient evaporation, the brines are pumped into another pond where the sodium chloride crystallizes and precipitates. This last process is repeated 4 or 5 times in order to precipitate the maximum of sodium chloride and other salts. Afterwards, slake lime is added to precipitate $\mathrm{Ca}$ and $\mathrm{Mg}$ salts, producing gypsum and magnesia. Additions of slake lime and transfers to other ponds are made until the brine has $0.5 \%$ lithium, when it is transferred to a processing plant that extracts the lithium as lithium carbonate. On total, including the lime production, it takes $40.2 \mathrm{MJ}$ to produce $1 \mathrm{Kg}$ of $\mathrm{Li}_{2} \mathrm{CO}_{3} .78 \%$ of the required energy for production is from oil fuels, $4 \%$ is derived from propane and the rest is mostly from coal. (L. Gaines, J. Sullivan, A. Burnham, I. Belharouak, 2011).

The other source of lithium, spodumene, is a mineral that consists of lithium aluminum inosilicate $\left(\mathrm{LiAl}\left(\mathrm{SiO}_{3}\right)_{2}\right)$. Due to the high cost, the production from spodumene was abandoned in the past. However, the increasing lithium demand made producers consider this process again. The high cost of this type of production derivess from the high-energy consumption of the process. Spodumene must be treated at $1000^{\circ} \mathrm{C}$ to achieve the required structural transformation, which is to go from an alpha to a beta form enabling acid leaching using sulfuric acid. Lithium is then retrieved in the form of lithium salts. Besides the energy to heat up the mineral, the whole process of mining and milling the ore also demands high-energy consumption.

\subsubsection{Production of the Cathode}

Cathode materials are typically made of different mixtures of lithium carbonate and transition-metal precursors by calcination at high temperatures, in the range of 600 to $800^{\circ} \mathrm{C}$. This process usually requires fossil fuels. The key factors for the quality of the cathode are the structural and physical properties of the final materials, for example the morphology and packing density. 


\subsubsection{Production of the Anode}

Li-ion batteries usually have carbonaceous anodes that can be presented in different forms by using natural graphite, hard carbon, soft carbon or mesocarbon microbead for lithium insertion anodes. This process also requires fossil fuels and is very energy-intensive, since the production of any synthetic graphite material needs $2700^{\circ} \mathrm{C}$ for full graphitization.

As already mentioned on the section 2.3, lithium titanate (Li4Ti5O12) material has recently gained attention as a high-power anode material, which has a lower energy need and can replace graphite anodes in Li-ion cells. Its production occurs trough the reaction of lithium carbonate $(\mathrm{Li} 2 \mathrm{CO} 3)$ and Titania $(\mathrm{TiO} 2$ in its anatase crystalline form) at $850 \mathrm{oC}$ under air.

\subsubsection{Cell production}

The typical process to produce a Li-ion cell, for both commercial small size and larger ones, which could be used, for example, for electric vehicles, can be described as follows:

1. LiCoO2 powder (80-85\%), binder powder, solvent, and additives in a chemical vessel are used to make a cathode paste that is pumped into the coating machine;

2. The coaching machine spreads the paste on both sides of an aluminum foil until it gets about 200 to $250 \mu \mathrm{m}$ thick (on both sides). Afterwards the paste is dried and the thickness is reduced by $25-40 \%$. The foil is then calendared in order to get a uniform surface and cut into the desired width;

3. A similar process is used to produce the anode paste, which is then spread on a copper foil. In this case, a small amount of material is lost due to material trimmed off the edges of the foils and due to the change of foil rolls. This material can be recycled;

4. The layers of anode, separator and cathode are then wound up and inserted into cases that can be cylindrical or rectangular;

5. Cells are then filled with electrolyte; 
6. Insulators, seals, valves, safety devices, etc., are attached, and the cells are crimped closed (or welded);

7. A cycler charges the cells. In the case of electric vehicles battery the cycler needs to provide higher current when compared to the commercial small batteries. Cells are now ready to be tested. They are left on the test stand for several days and then discharged; this process is repeated about four times to verify the quality of the product;

8. Cells are equipped with electronic circuit boards to control charging/discharging and packed into cases;

9. Finally, the defective cells (around 1\%), some non-homogeneous electrode material, and a few left overs are discarded, and can be sent for recycling.

The Figure 2.7 bellow, from the Argone National Laboratory - Chemical Sciences and Engineering Division, is a detailed scheme of the process above described.

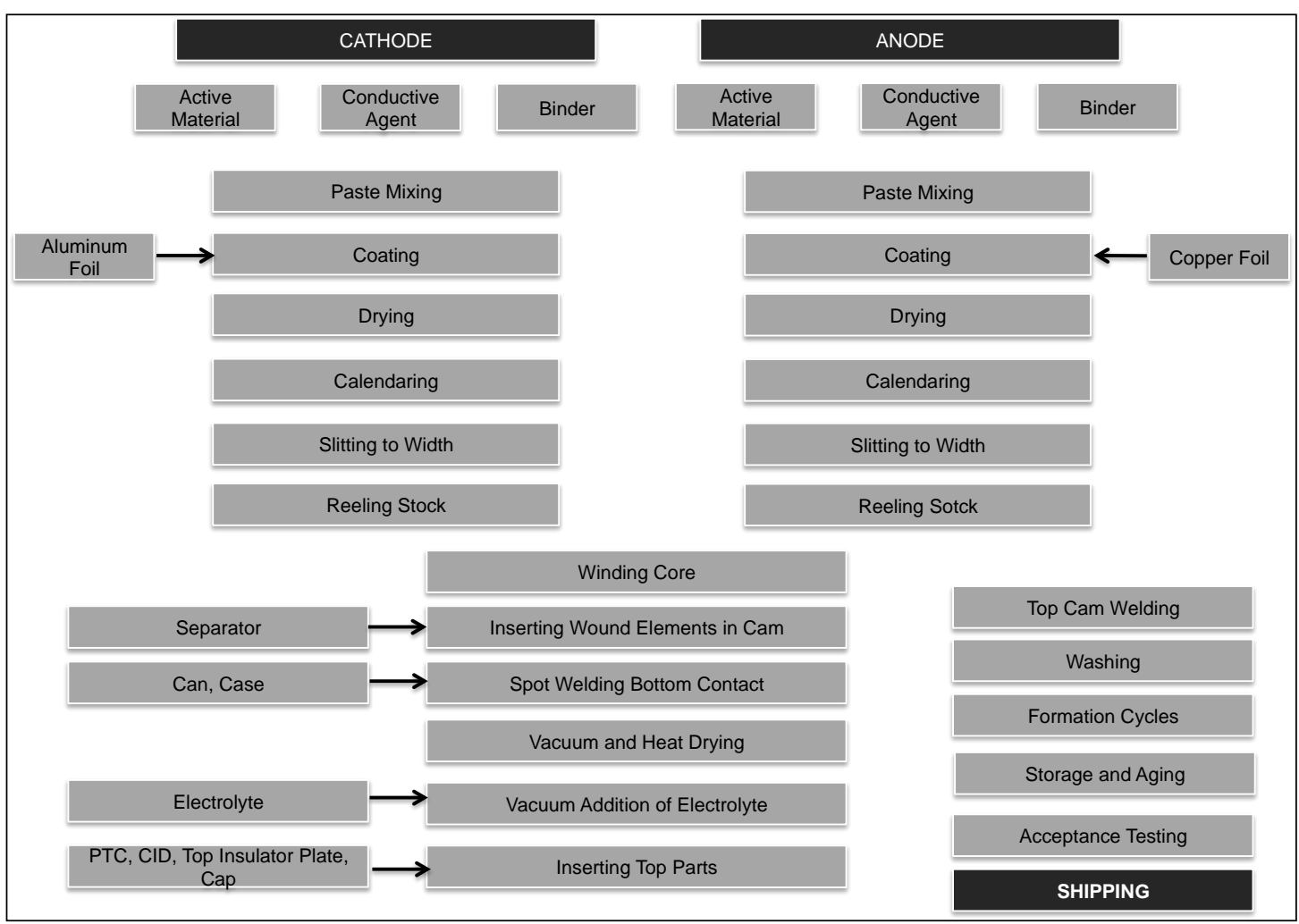

Figure 2.7 - Scheme of a battery production

Source: Argone National Laboratory, Chemical Sciences and Engineering Division, 2011. 


\subsubsection{Use Phase / Efficiency and Lifetime}

The efficiency and lifetime of a battery is directly related, among other factors, to its use. Speaking more specifically about the direct efficiency, it is influenced by many factors such as temperature, number of uses, environmental factors, power demand, and depth of discharge and age of the battery. Many studies have pointed the average efficiency for a lithium battery as 90\% (Rydh and Sandén, 2005a; Matheys et al., 2007).

Lifetime of a battery depends mostly on chemical factors and use conditions, which means that a gentle use would prolong its lifetime. The longer the lifetime the higher are the number of cycles throughout its use phase.

\subsubsection{Recycling phase}

The recycling process of a battery, including the Li-ion battery, varies substantially according to the feedstock. The process might only be able to recover one useful product of a multi-component product, or even recycle the whole product but into lower value material.

The recovery of the battery-grade is only possible by means of a very uniform feed. In this case, the product goes through several physical and chemical processes to separate all the components. Once separated, all the metals and active materials may be recovered, except for the separator, which form can't be preserved.

The Figure 2.8 shows an example of battery recycling process. This process is used by the European company Umicore, where the recovery rate of Li-ion batteries is considered at $93 \%$, from which $69 \%$ are metals, $10 \%$ carbon and $15 \%$ plastic. However, the high-value usable materials represent a much smaller percentage (Gaines, Sullivan, Burnham, and Belharouak, 2011). 


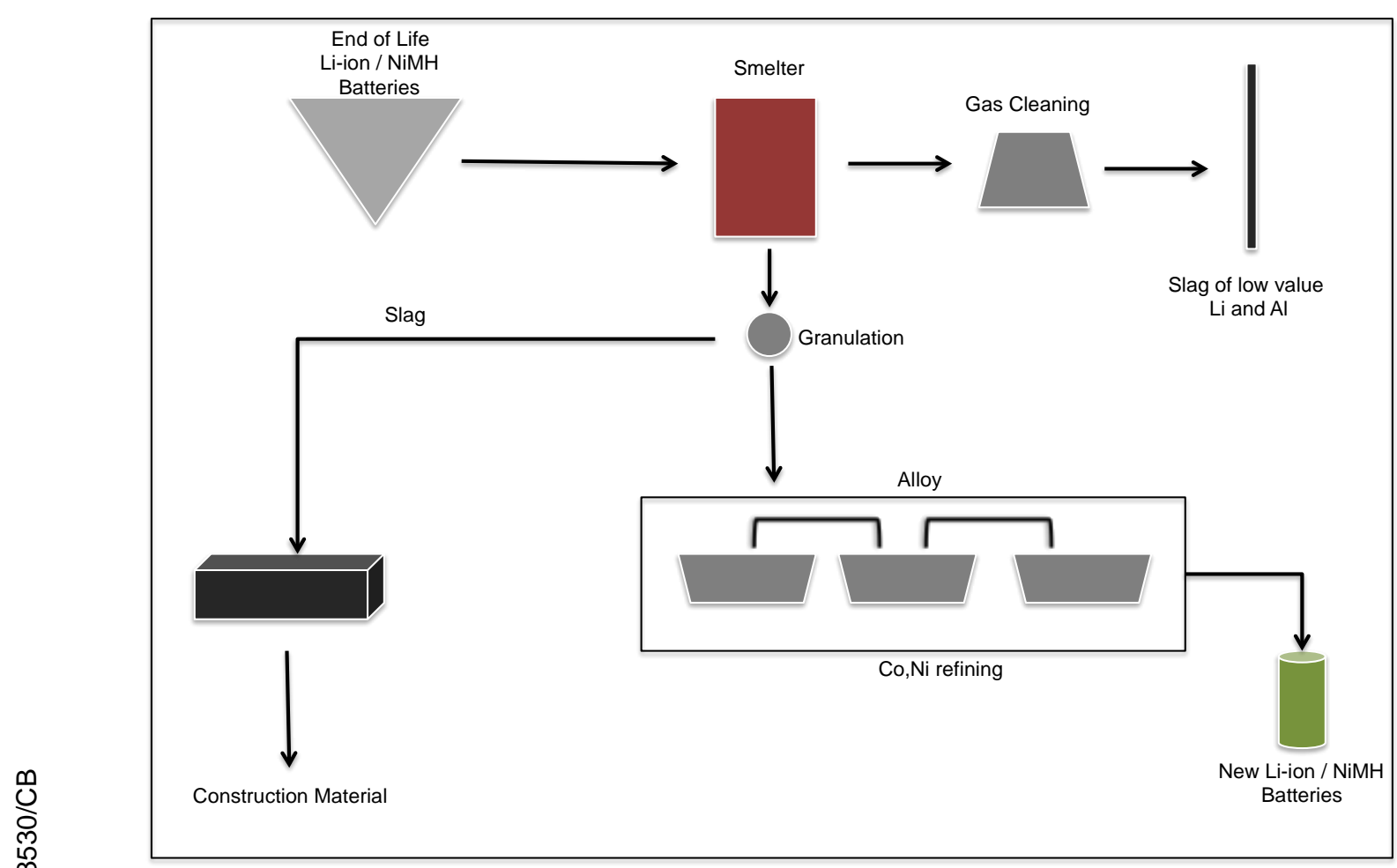

Figure 2.8 - Umicore recycling process

Source: Gaines, Sullivan, Burnham, and Belharouak, 2011.

Lithium-ion technology in general still needs further improvements to meet its theoretical energy density limit, such as innovations in battery pack energy density, operating temperature range, and cycle life. These improvements are also important for its cost reduction and increase in battery life.

\subsection{German Energy Production}

As one of the biggest economies in the world, Germany is also a big energy consumer. According to the U.S. Energy Information Administration (EIA), in 2012 Germany was the biggest energy consumer in Europe.

In 2012 the main German energy source were fossil fuels, about $37 \%$ of the total primary energy consumption in the country. The country is one of the largest refiners in the world, with over 2.2 million barrels per day. Most of the petroleum product demand comes from the transportation sector, despite the 
government's 2010 "Energy Concept" publication that set the goal of one million electric vehicles on the road by 2020, and six million by 2030 .

With respect to natural gas (LNG), Germany has no liquefied gas terminals, making it necessary to import the natural gas exclusively through several major cross-border pipeline networks. Almost all natural gas imports come from Russia, Norway and the Netherlands. Due to energy efficiency improvements, the natural gas consumption in Germany has declined from nearly 3.6 trillion cubic feet (Tcf) in 2003 to 3.1 Tcf in 2012. Between 2012 and 2013, the share of electricity from gas declined about $21 \%$.

The most abundant energy resource in the country is coal (both brown and hard coal), which represented $24 \%$ of the total primary consumption in 2012, serving mainly the power and industrial sectors. The coal consumption increased after the Fukushima reactor accident occurred in March 2011, after which the German government decided to close eight of the nuclear reactors and set the target of having the nine remaining reactors closed by 2022. Despite the closing of the eight reactors in 2011, in 2012 Germany was still the fifth-largest generator of nuclear energy in the world, with a production of 94.1 TWh.

According to the IEA, German electricity production has decreased between 2010, with a 629TWh generation, and 2012, with a 618 TWh gross production. In 2012 coal provided $286 \mathrm{TWh}$ (46\%, more than half being lignite), nuclear $100 \mathrm{TWh}(16 \%)$, gas $70 \mathrm{TWh}(11.32 \%)$, biofuels \& waste $48 \mathrm{TWh}$ (7.77\%), wind 46 TWh (7.44\%), hydro 28 TWh (4.5\%), and solar 28 TWh (4.5\%). Electricity exports exceeded imports by about $20 \mathrm{TWh}$, compared with 4 TWh in 2011, but Germany is one of the biggest importers of gas, coal and oil worldwide, and has few domestic resources apart from lignite and renewables. The annual consumption in the country is about $6400 \mathrm{kWh}$ per capita.

In 2013 the nuclear energy production suffered once more a slight decrease, of around $2 \%$, while the energy generated by brown coal increased $2.3 \%$ and hard coal $4.2 \%$. The gas production suffered a significant decrease, of about $21 \%$, as well as hydro power, which decreased $7.2 \%$. Wind energy increased $2.9 \%$ and solar energy $6.3 \%$ (Fraunhofer, 2014). The chart 2.4.1 shows the electrical energy generated in Germany during 2013. 


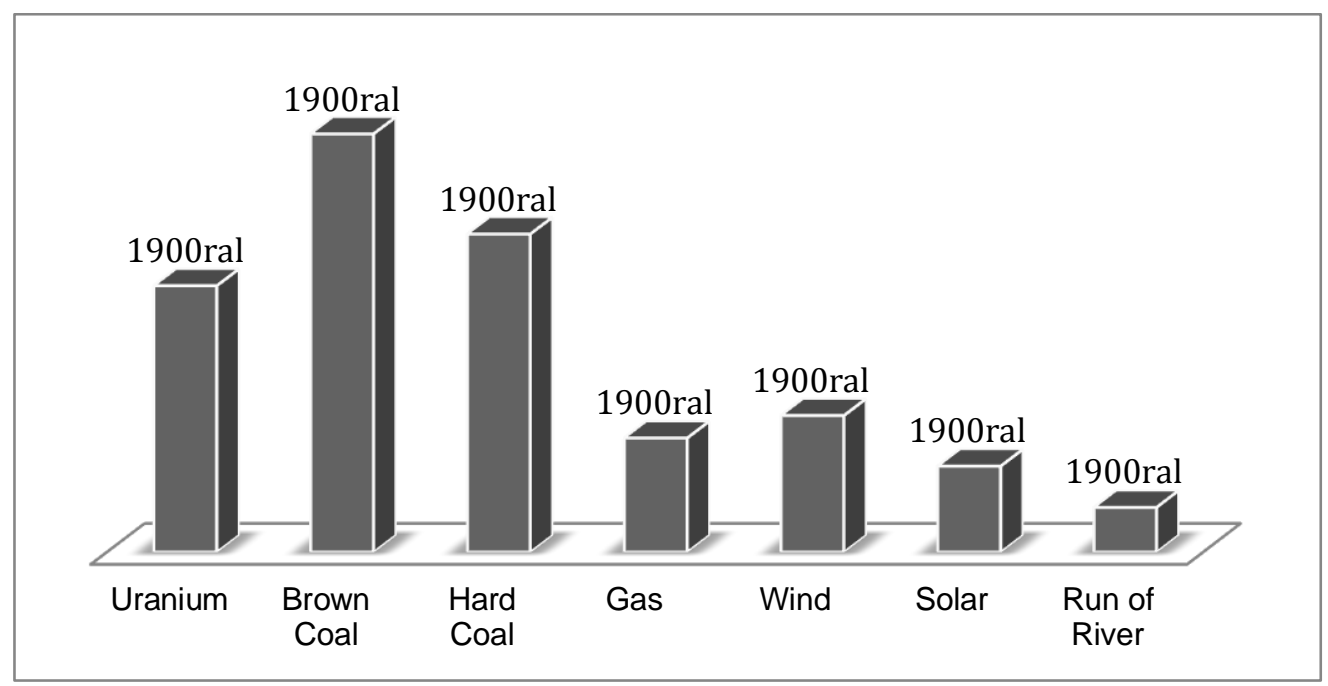

Figure 2.9 - Electricity generated during 2013 in TWh

Source: Fraunhofer Institute, 2014.

As shown on Figure 2.9, in the first eleven months of 2014 gas-fired output dropped a further $18.4 \%$ to $29 \mathrm{TWh}$, lignite provided $129.3 \mathrm{TWh}$, hard coal 90.7 TWh, nuclear 83.3 TWh, wind 42.6 TWh, solar 32.4 TWh, biomass 48.6 TWh and hydro 16.8 TWh. Hydro power suffered the highest decrease, of $28.6 \%$ when compared to the same period of the previous year. Total electricity production for the first eleven months of 2014: 471.7 TWh, of which approximately 33.8 TWh was exported, as shown on Figure 2.10.

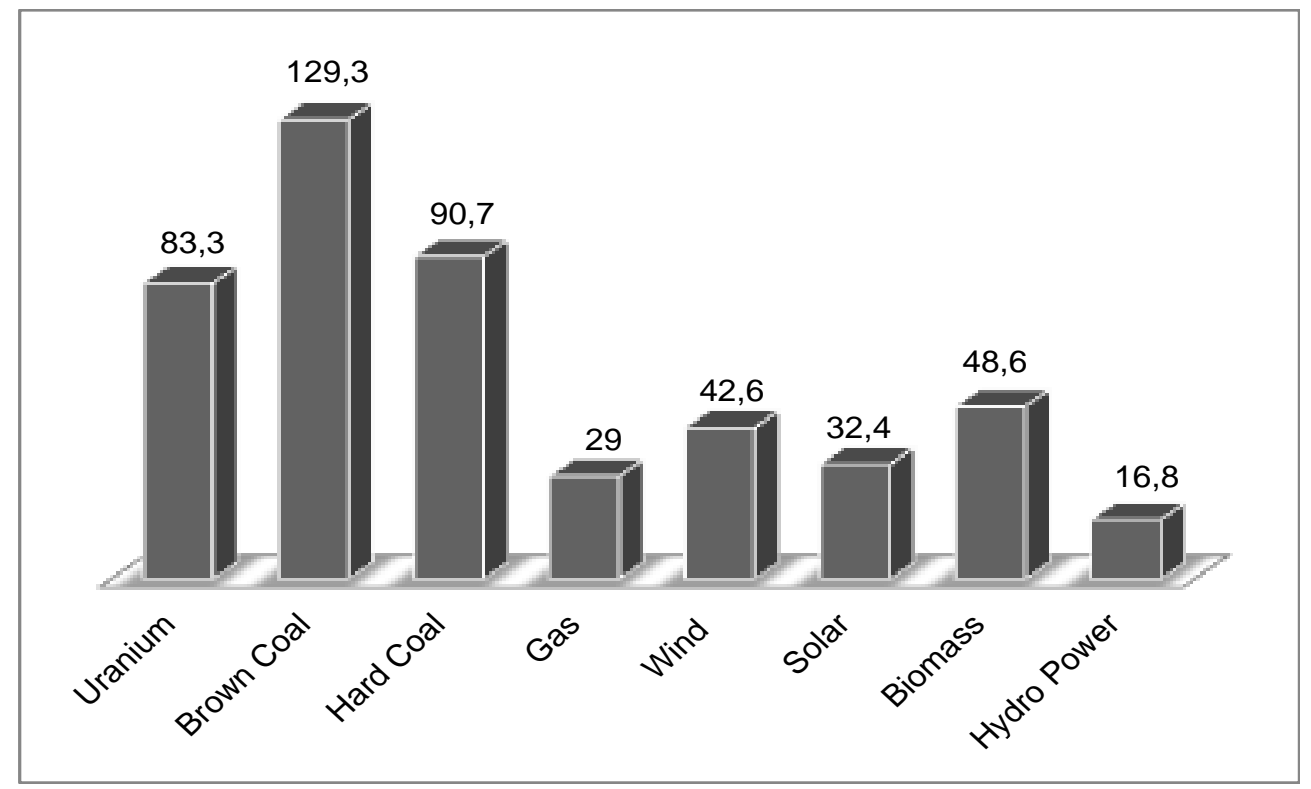

Figure 2.10 - Energy generated on the first eleven months of 2014 in TWh Source: Fraunhofer Institute, 2014. 
In the last decade, Germany has presented a significant electricity export surplus. However, in 2011 there was a major surplus reduction relative to previous years, due to the shut down of the 8 nuclear usines, as can be seen in Figure 2.11.

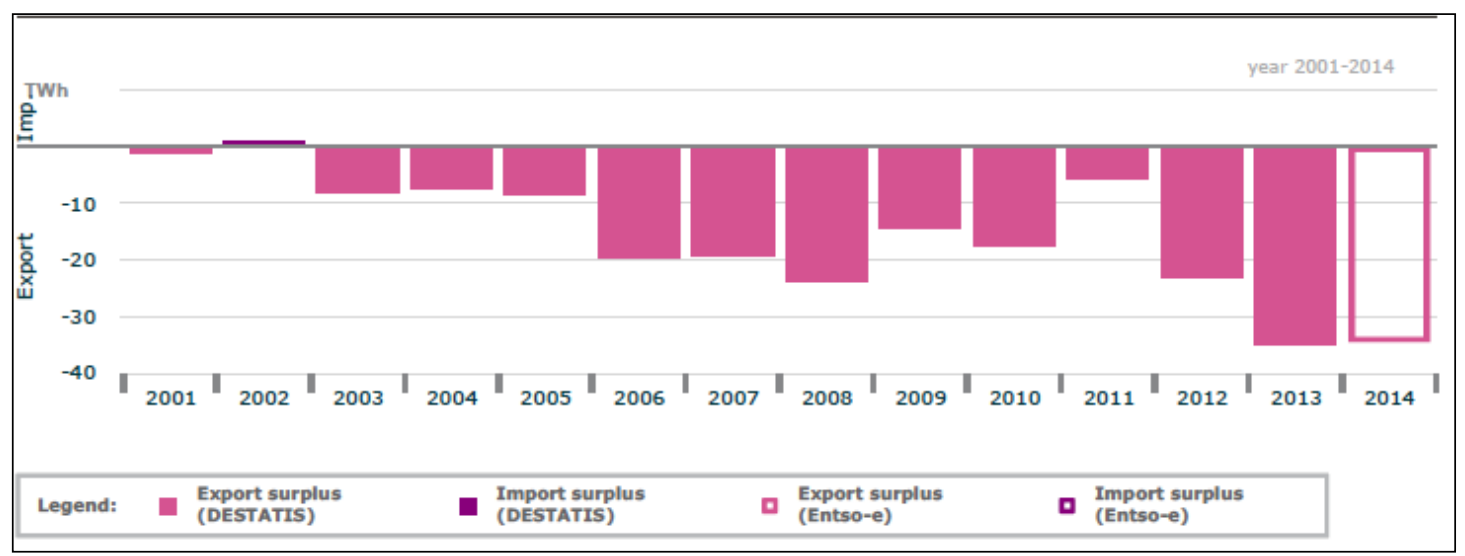

Figure 2.11 - Electricity export and import balance since 2001

Source: Fraunhofer Institute, 2014.

The renewable energy generation in 2014 and the future prospects for its production in Germany will be detailed on the following section.

\subsubsection{Renewable energy generation: Overview 2014}

Germany is world leader in many categories of renewable energy use. In the first eleven months of 2014 Germany produced 32.4TWh of solar energy, an increase of $7.4 \%$ (2.2TWh) when compared with the same period of the previous year. The increase could have been higher if it wasn't for the bad weather experienced in the last months of the year (Fraunhofer Institute for Solar Energy Systems, 2014).

The production of eolic energy in the same period was 42.6TWh, which represents a decrease of $0.4 \%(0.2 \mathrm{TWh})$ when compared with the first eleven months of 2013. Solar and Wind energy put together represent 75TWh, not far from the nuclear energy production. The biomass energy production was 48.6 TWh, presenting an increase of $12.6 \%$ (5.4TWh). On the other hand, the hydropower production has suffered a significant decrease. Its production in the 
first eleven months of 2014 was $16.8 \mathrm{TWh}$, which represents a reduction of 6.7 TWh (28.6\%) in comparison with the same period of 2013. Here is important to mention that Germany considers hydropower as renewable energy, when often it isn't considered renewable due to its impact on wildlife.

Considering all the renewable sources together, the total production in the first eleven months of 2014 was of $140.4 \mathrm{TWh}$. This represents a share of $29.7 \%$ of the public net electricity production. Germany's clean energy expansion happened thanks to the high investment that has been made since 2000 . Consumers, including shop owners, companies and private citizens have paid 106 billion euros ( $\$ 130$ billion) to finance this expansion trough an extra charge into the energy bill.

\subsubsection{Solar Power production potential in Germany - Photovoltaic}

The solar power potential in Germany, shown in Figure 2.12, can be considered as being quite small due to its high latitude. Analogously the potential is higher on the South of the country where the latitude is lower. In spite of the low solar power potential, Germany is the world leader in PV energy production due to its strong incentive polices, including for example the feed-in tariff. As mentioned on the previous subsection, in $2013 \mathrm{PV}$ power production in Germany was $30 \mathrm{TWh}$, representing $5.7 \%$ of the German net electricity consumption (fraunhofer 2014), and renewables as a whole represented $29 \%$.

However, for technical and climate reasons, the solar power production in Germany reaches over $70 \%$ of the total installed capacity on only a very few days of the year. The rise rate of the nominal efficiency of new produced commercial wafer-based PV modules is of 0.3 percentage points. In 2013 the nominal efficiency was around $16 \%$, and in a peak performance could reach over $20 \%$. On average, each square meter of a PV module has a power of $160 \mathrm{~W}$; the high quality modules can reach $200 \mathrm{~W}$. For thin film modules, the nominal efficiency varies between 6 and 11 percent, with a peak performance of 12-13 percent. 


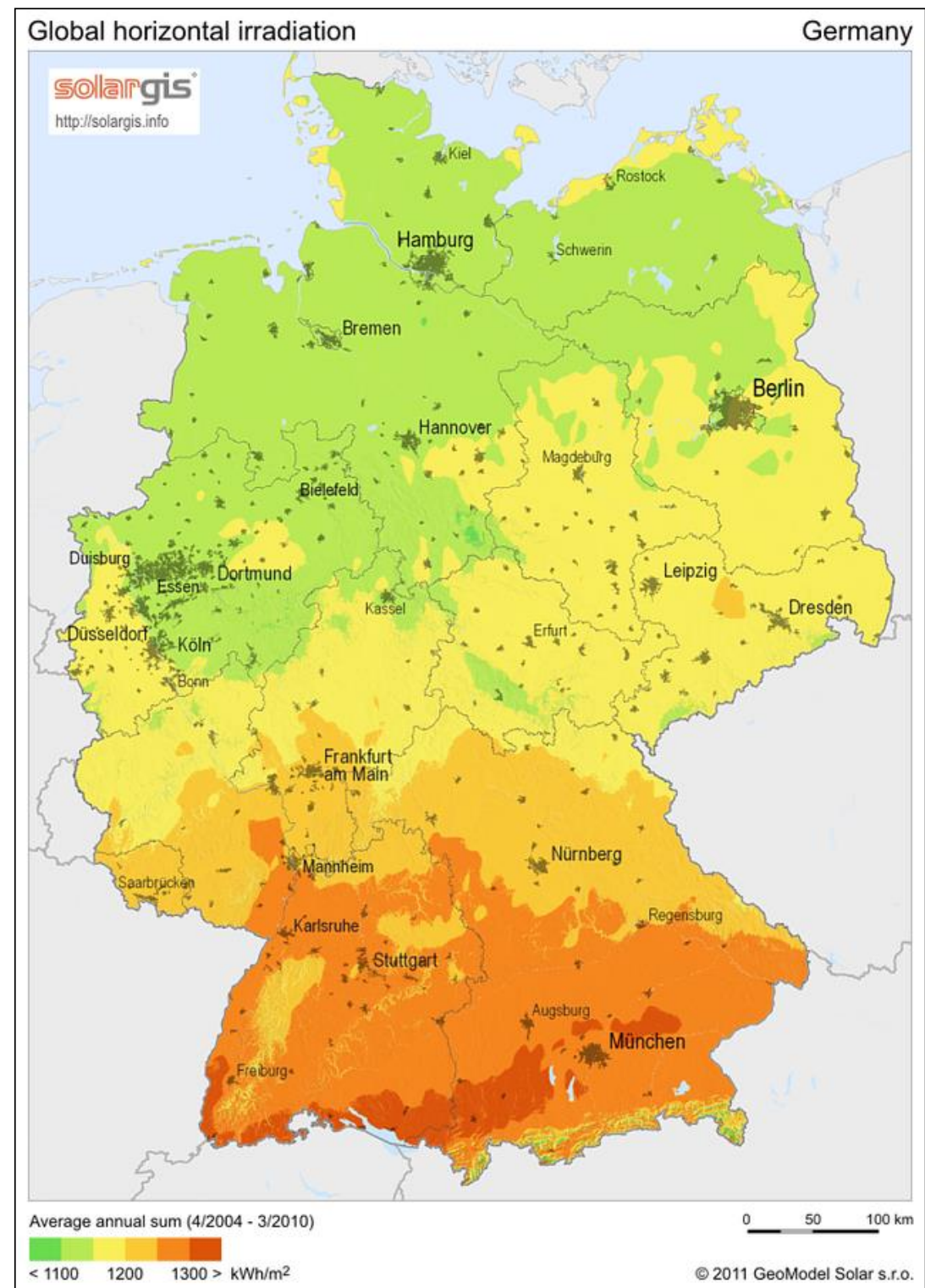

Figure 2.12- Average solar irradiation in Germany within a year period of time

Source: Solar GIS, 2011

On average, the performance of photovoltaic in Germany is greater from the beginning of April until the middle of September, due to the higher solar irradiation. The peaks of solar potential are reached (on average) from the beginning of June to the end of August. (SMA, 2014).

Considering all the losses that may occur during the operation, a welldesigned PV plant can reach a performance ratio (PR) of 80-90\% trhoughout the year (Fraunhofer, 2014). The losses can occur due to different reasons, such as: temperatures, irradiance conditions, dust on the PV module, and conversion losses in the inverter and line resistance. 
In Germany, depending on irradiance and ratio performance, the generation corresponds to about $150 \mathrm{kWh}$ per square meter of module, for high quality modules the generation can get to $180 \mathrm{kWh}$. That means a four-person household, which has and average consumption of $4400 \mathrm{kWh}$ electricity per year, need $30 \mathrm{~m}^{2}$ of new modules considering today's efficiency. Typically a southfacing roof of a family home can accommodate 20PV modules, which is enough to supply the family's electricity needs during the year.

Germany has proven to the world that the low solar power potential of the country, due to the average insulation throughout the year, does not mean that the country can't achieve a high share of renewables on its electricity net. Besides the heavy investments on renewable energy production, another fact that contributes to keep the high share of renewables on the country's electricity net is the complementarity characteristic between solar and wind sources in the country. In other words, when the solar potential is low the wind potential is high and vice versa, and if the investment in both energies keep growing at the same rate, it is possible to have a high share of renewable energy generation during the whole year, see Figure 2.13.

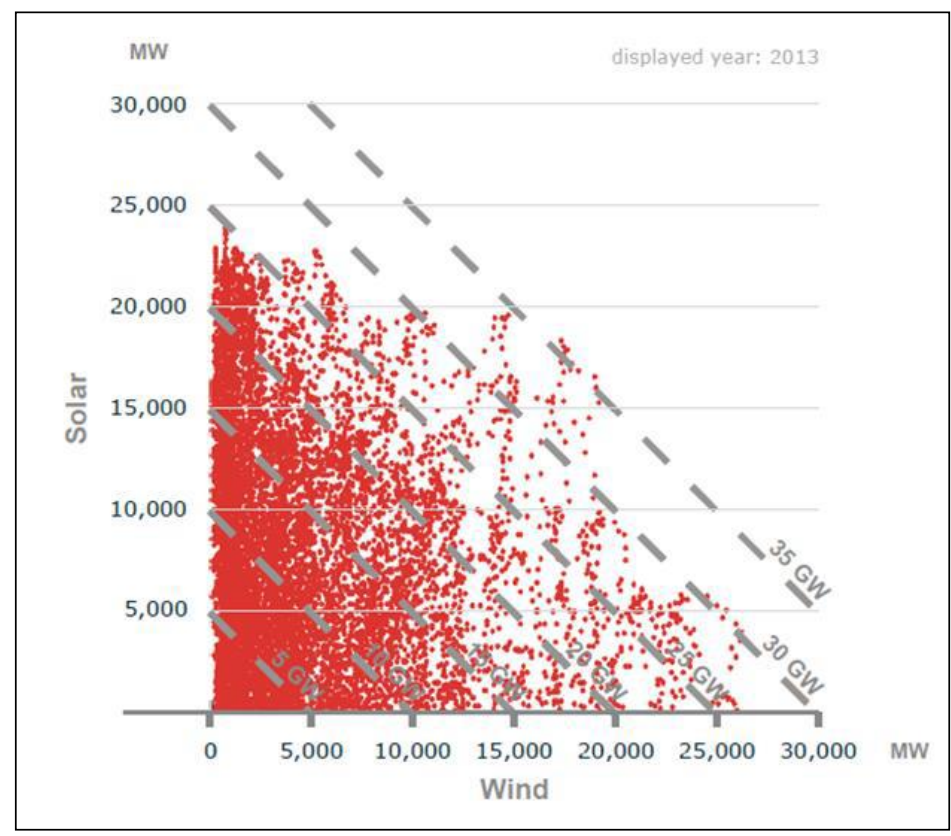

Figure 2.13 - Complementarity between solar and wind energies

Source: Fraunhofer, 2014. 
Figure 2.14 shows the monthly production of solar and wind energy during 2013 in order to give a better notion of the complementarity between the two energy sources.

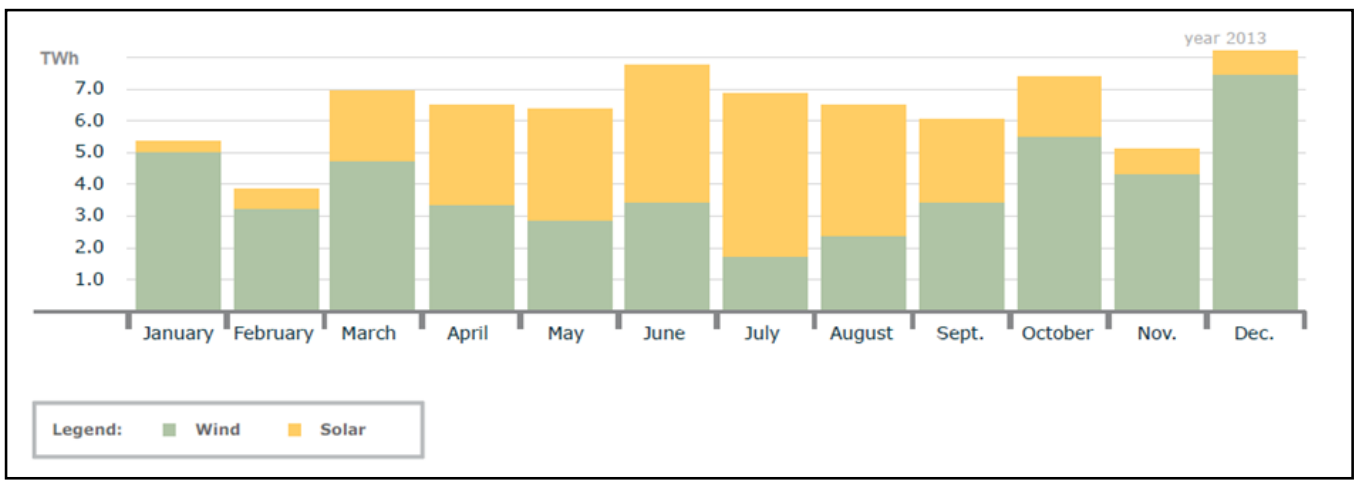

Figure 2.14 - Monthly production of Solar and Wind Energy

Source: Fraunhofer, 2014.

The production of both solar and wind energy are being constantly expanded on the country and reaching new production records. Nowadays there are 24200 wind turbines in Germany, with a land use of one-third the area of Berlin. This is a primordial investment to enable the reduction of nuclear energy need without increasing carbon emissions by the increase energy generated from coal. 


\section{STATE OF RESEARCH}

On this chapter results from some previous LCA studies on photovoltaic (PV) energy production and Li-ion batteries are presented, in order to support the results of this study, which will be presented on a further chapter. The section 3.1 discusses different LCA studies of PV energy generation, while the topic 3.2 presents different LCAs about Li-ion batteries.

\subsection{LCA of PV energy generation}

LCA studies for photovoltaic power plants have existed for over 15 years. The studies that have been published so far show a high variation in results and conclusions. Some critical issues during modeling of an LCI for photovoltaic power, which may lead to this result differences, are: modeling of silicon inputs and use of off-grade or solar grade silicon, allocation between different silicon qualities, power mixes assumed for the production processes, and process specific emissions (Jungbluth et al., 2004).

For the life cycle assessment, all the steps of the solar energy generation process must be considered, which includes consumption of working material (acids, oxygen, nitrogen and highly purified water), electricity, and wastes as well as the specific air- and waterborne pollutants. Another point to be observed is that since PV technologies have been improved constantly, the studies must be regularly updated in order to keep its consistency.

The production of solar cells includes purification and etching of the wafers. Afterwards, wafers are endowed with phosphorus and, after further etching processes, front and rear contacts are printed. Cell efficiencies are usually estimated with data provided by several different producers.

According to Jungbluth et al. (2004), the installation is a very important phase for the Individualist perspective of the Eco-indicator 99, which gives a high weighting to the use of metal resources. This means that different types of resource uses or pollutants might be more or less important for the final result, depending on the impact assessment method.

The highest contribution of environmental impacts comes from the use of fossil energy resources on the PV system production chain, which emissions 
contribute to climate change, incidence of respiratory diseases, among other impacts.

Plants using mono-crystalline cells have higher impact than those with polycrystalline cells for most of the impact categories. One way to reduce the environmental impacts of PV power plants is by improving the production processes, which may occur in the future. Regarding carcinogenic effects, a higher share of these effects may be a result of a different assumption for the electricity supply in the considered scenario (Jungbluth et al., 2004).

The study from Jungbluth (2004), which had some of its data updated in 2008, also show that an important parameter for the assessment of renewable energy systems is the estimation of the energy and/or environmental payback time. That means the time needed until the environmental impacts from the production of the plant studied have leveled out due to avoiding resource uses and/or emissions of a conventional reference system that produces the same amount of electricity. For the different PV plants this time is between 3 and 6 years. That means the energy used on the PV plant production is as high as the energy used during 3 to 6 years of a gas power plant operation.

The lifetime of a PV power plant is considered by most studies as 30 years. The pay-back time is usually five to ten times shorter than the plant's expected lifetime. This picture changes according to the parameters that are being considered, for example when emissions are taken into account.

Valuating the impact with the method of ecological scarcity (Umweltbelastungspunkte - UBP) gives an environmental payback time of about 25 years (Brand et al. 1998, Frischknecht et al. 2004c), while the pay-back time evaluated with Ecoindicator 99 (number that express the total environmental loaf of a product or process) is slightly higher than for the energy demand. When human toxicity is taken as an indicator, it might be even higher than 50 years, and therefore longer than the expected lifetime (Guinée et al. 2001). The reasons for these big differences between the selected LCIA methodologies are manifold: in EI99 (H,A), the consumption of fossil resources is considered as very important, but not so important in ecological scarcity and not included in the human toxicity category indicator; the PV chain produces higher emissions of human toxic species than the gas chain. The outcome of such a comparison is influenced by the choice of the reference system, on the one hand, and by the indicator, on the other. 
Making an evaluation of the elementary flows over the life cycle of a PV system enables the understanding of how important each production stage is for certain elementary flows. Figure 3.1 shows the shares of different production stages for some selected elementary flows of a slanted-roof installation with a multicrystalline silicon panel. This study shows, for example, the high share of Biological Oxygen Demand (BOD), which is caused by the finishing of wafer surfaces.

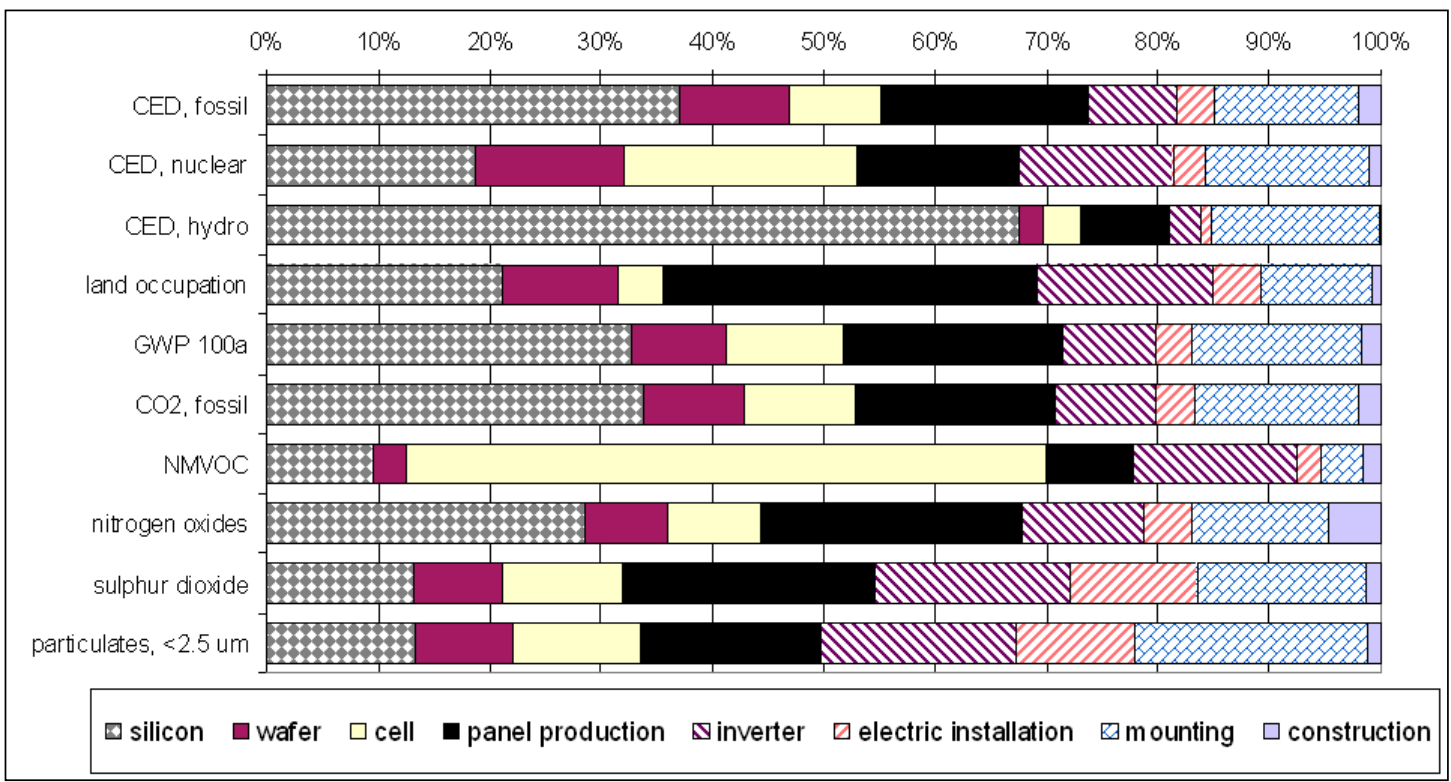

Figure 3.1 - Share of process stages for a Swiss grid-connected, 3kWp slanted-roof installation with a multicrystalline silicon panel for selected elementary flows of the inventory. CED = Cumulative Energy Demand.

Source: Jungbluth, N., 2008.

As previously mentioned, an important index for the assessment of renewable energy systems is the energy and environmental payback time. The result of such comparison varies according to the reference system, due to the difference of irradiation in different areas, and to the different characteristics from PV systems, such as type of panel and type of installation. Figure 3.2 shows an example of results where the reference system was the UCTE energy mix in 2004. The outcome for this study was a pay back time that ranges from 2.5 to 4.9 years for the different types of PV plants. In other words, depending on which PV 
technology is used, the pay back time is 5 to 10 times shorter than the expected lifetime of the photovoltaic power plants.

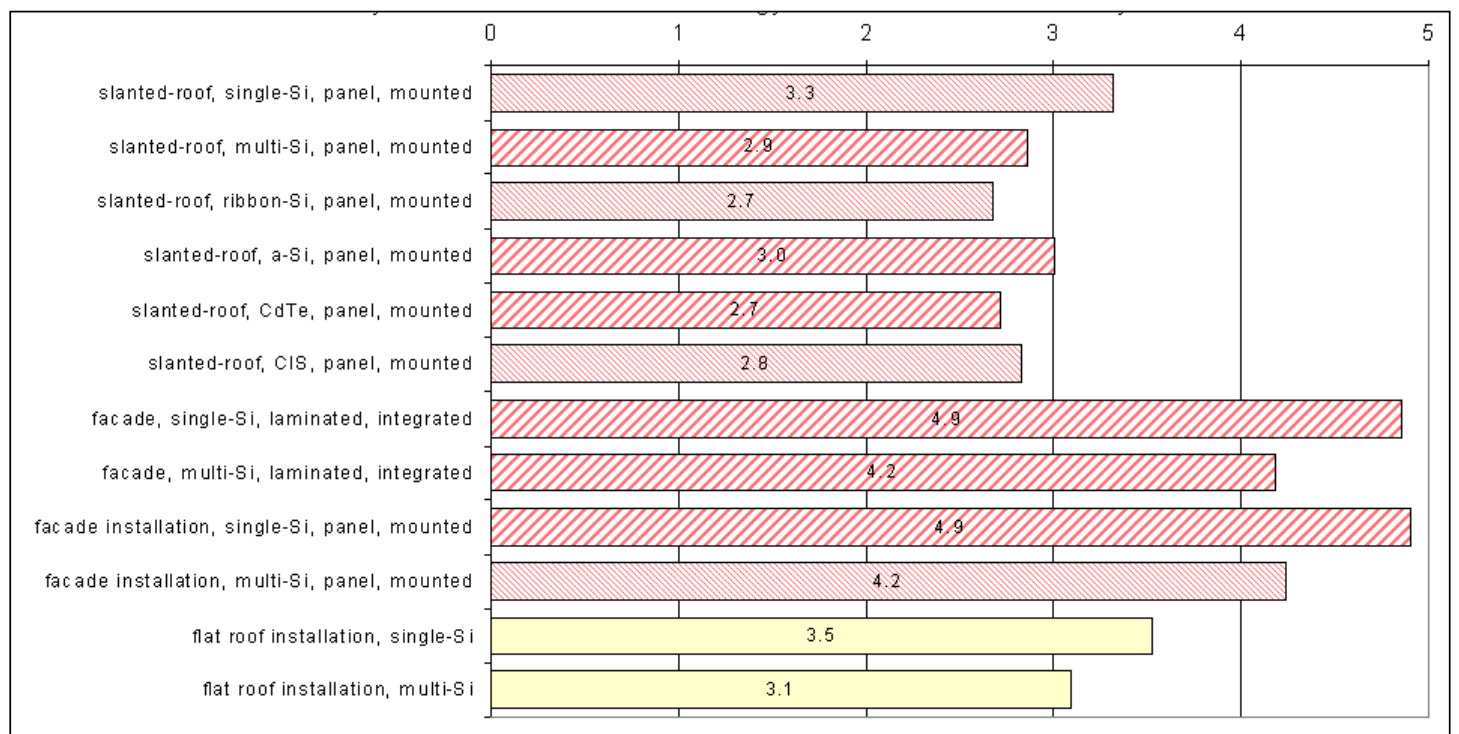

Figure 3.2 - Energy payback time of 3Kwp PV plants in Switzerland in relation to the UCTE electricity mix.

Source: Jungbluth, N., 2008.

Another study, from R. Battisti and A. Corrado (2003), compared photovoltaic and hybrid photovoltaic/thermal (PV/T) systems and concluded that the heat recovery can considerably increase the environmental benefits, since the PV/T have a significantly lower, both energy and environmental, payback time when compared to the non-hybrid system. The Table 3.1 shows the results, for the payback time of, where the reference system was a multi-crystaline silicon (mc$\mathrm{Si}$ ) photovoltaic system on a tilted roof in Rome with an average insulation of $1530 \mathrm{KWh} / \mathrm{m}^{2}$.

Table 3.1 - Energy and environmental pay back time for PV and PV/T systems

\begin{tabular}{|lll|}
\hline & EPBT (years) & $\mathrm{CO}_{2 \mathrm{eq}}$ PBT (years) \\
\hline PV mc-Si system (flat roof) & 3.3 & 4.1 \\
PV/TH (space heating) & 2.8 & 2.8 \\
PV/TH (DHW, replacing natural gas) & 2.3 & 2.4 \\
PV/TH (DHW, replacing electricity) & 1.7 & 1.6 \\
\hline
\end{tabular}

Source: Battisti R. and Corrado A., 2003. 
Another PV LCA study, from Tripanagnostopoulos et al. (2005) also concludes that the best performance PV system would be a hybrid photovoltaic/thermal system. This study goes on further details pointing the PV/T system with glazing (with or without reflector) and operating at $25^{\circ} \mathrm{C}$ as the best performance system. At high temperatures, such as $45^{\circ} \mathrm{C}$, the performance is satisfactory only for the unglazed systems. The use of a reflector can increase both electricity and thermal outputs.

Many studies have shown that PV technologies have suffered significant improvement during the past decade, presenting a substantial reduction of their environmental impact. Another fact observed is that the performance and type of the plants are of high relevance for their environmental impact. Finally, most authors have emphasized the importance of the local irradiation for the efficiency of the system. Thus, Jungbluth (2008) defends the necessity of installing PV power plants in areas with higher irradiation level, in order to achieve a high share of renewable energy worldwide. Consequently, the present focus of the German market is not considered as an ideal solution.

\subsection{LCA of Lithium Battery}

As mentioned in section 2.3, Li-ion batteries have been increasingly gaining importance on the industry due to its low memory effect, which means that it can be charged and discharged many times without lost of capacity. At first they took over the electronics market and started to be largely used by the computer and cell phone industry. More recently it has been also used for electrical vehicles and other applications that require larger batteries.

However, the comprehension of life cycle inventory data for battery technologies is still a major problem (Sullivan and Gaines 2012), since most of the recent LCA studies on batteries concentrate on their application for automotive purposes (Shanika Amarakoon \& Segal 2013), and are based more towards a couple of battery technologies, Lithium Ion and Lead Acid.

According to Gaines and Cuenca (2000) and Nelson et al. (2009), the highest share on the battery cost comes from the anode and cathode material choices. These materials are also responsible for the total storage capacity, and their structural and chemical composition determines the efficiency and the rate of 
the energy flow that comes out of the battery. In regard to the life cycle for lithium chemistries, the reactions at the electrode/electrolyte interface play the biggest role (Tarascon and Armand, 2001, Vetter et al., 2005 and Broussely et al., 2005).

A study from Hiremath (2014) pointed both Li-ion and sodium sulfur batteries as the least environmentally friendly in regard to the global warming potential (GWP) and cumulative energy demand (CED) impact categories, when compared to lead acid and vanadium redox-flow per $\mathrm{Kg}$ of battery mass. The cradle-to-gate CED values for Lithium Ion, Lead Acid, Sodium Sulfur and Vanadium Redoxflow are $180.1,29.5,180.7$ and $28.8 \mathrm{MJ} / \mathrm{kg}$, respectively and the corresponding GWP values are 11.2, 3.3, 14.9 and $2.1 \mathrm{kgCO} 2 \mathrm{eq} / \mathrm{kg}$. However, when compared by MWh basis, the lithium ion and sodium sulfur show a lower impact. In this case, the mean cradle-to-gate CED values for Lithium Ion, Lead Acid, Sodium Sulfur and Vanadium Redox-flow are 154, 814, 443 and $160 \mathrm{MJ} / \mathrm{MWh}$; and the corresponding GWP values are 10, 91, 36 and $11 \mathrm{kgCO} 2 \mathrm{eq} / \mathrm{MWh}$ (see Figure $3.3)$.

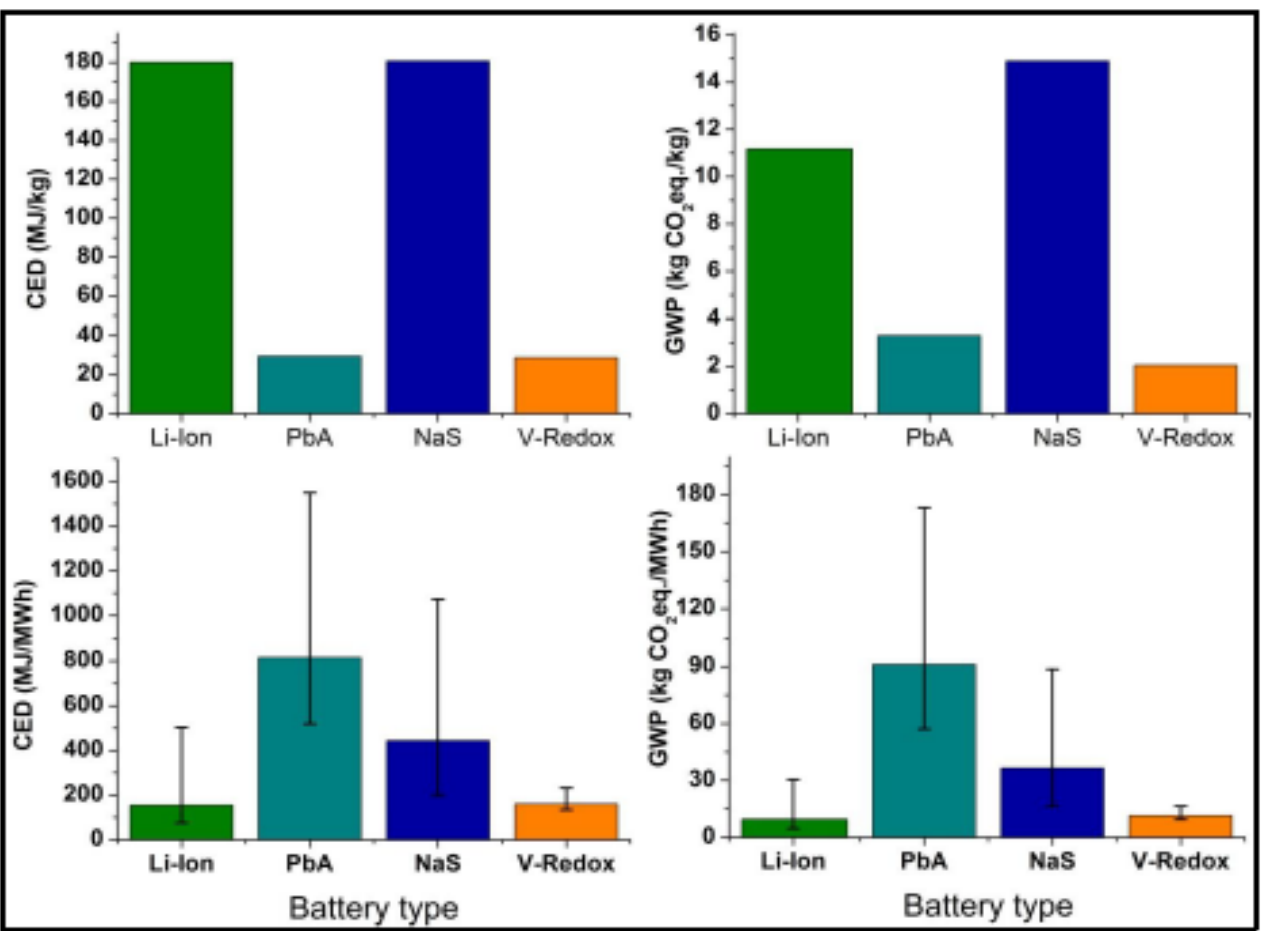

Figure 3.3 - Average cradle-to-gate values per KG of battery and the cradleto-gate values per MWh of electricity output calculated in this study

Source: Hiremath M., 2014. 
These differences in result can be attributed to three reasons. The first reason is that the battery electricity storage capacity depends primarily on the number of cycles during its lifetime (cycle life), and Li-ion and sodium sulfur batteries have a cycle life of, respectively, 8.2 and 2.6 times larger than the cycle life of lead acid batteries. The second reason is that the mass of a battery depends on its energy density, and Li-ion and sodium sulfur have respectively 3.7 and 4.2 times higher energy density than lead acid batteries. Finally, the system size required for a specific application depends on the round-trip efficiency of the battery (Hiremath M., 2014).

When the use stage is considered, it is observed that the impact also vary across the four battery technology types, that were considered in the study from Hiremat (2014). This variation is a result of the differences in the round-trip efficiencies of the battery technologies. The Lithium Ion has a high round-trip efficiency, around 90\%, and therefore has the least use stage impacts (12555 MJ/MWh \& 799 kg CO2eq/MWh), while Vanadium Redox-flow, with a roundtrip efficiency of $75 \%$, has got the highest use stage impacts $(15067 \mathrm{MJ} / \mathrm{MWh} \&$ $959 \mathrm{~kg} \mathrm{CO} 2 \mathrm{eq} / \mathrm{MWh})$. In other words, the more efficient the battery system, the lower are the losses and hence lower the use stage impacts resulting from electricity consumption. These results are shown in Figure 3.4.

Since the use stage phase has the largest share in the overall impacts, the Li-ion battery becomes more competitive when seen from the life cycle perspective, due to its very low use stage impacts. The underutilization of the battery has a big effect on its impact. This means that, as the number of cycles demanded by the application increases, the CED and GWP impacts of Li-ion batteries decrease drastically. When getting into a detailed LCIA of Li-ion battery it can be noticed that electricity used during manufacturing stage has the highest share on the CED impact category, while the cathode production shows the highest impact on the GWP (see Figures 3.5 and 3.6). 


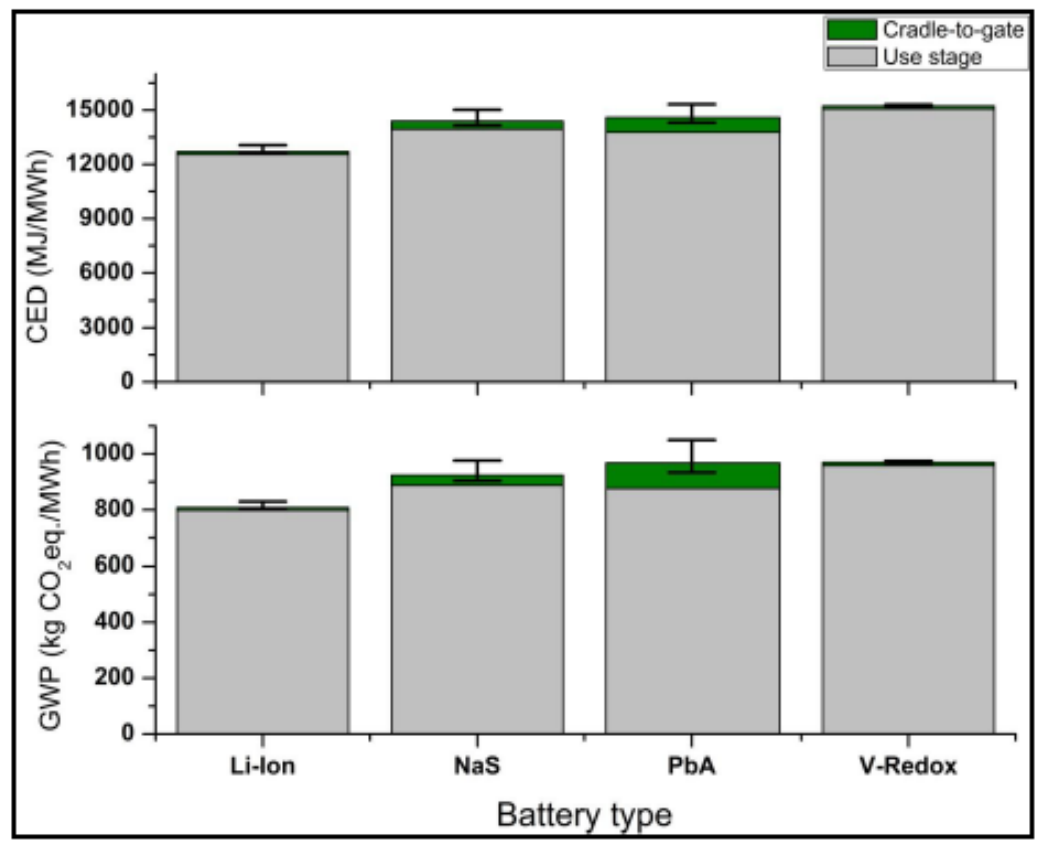

Figure 3.4 Life cycle battery impacts showing the contributions from cradle-to-gate and use stages of the batteries.

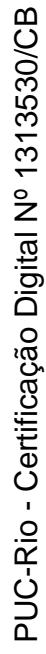

Source: Hiremath M., 2014.

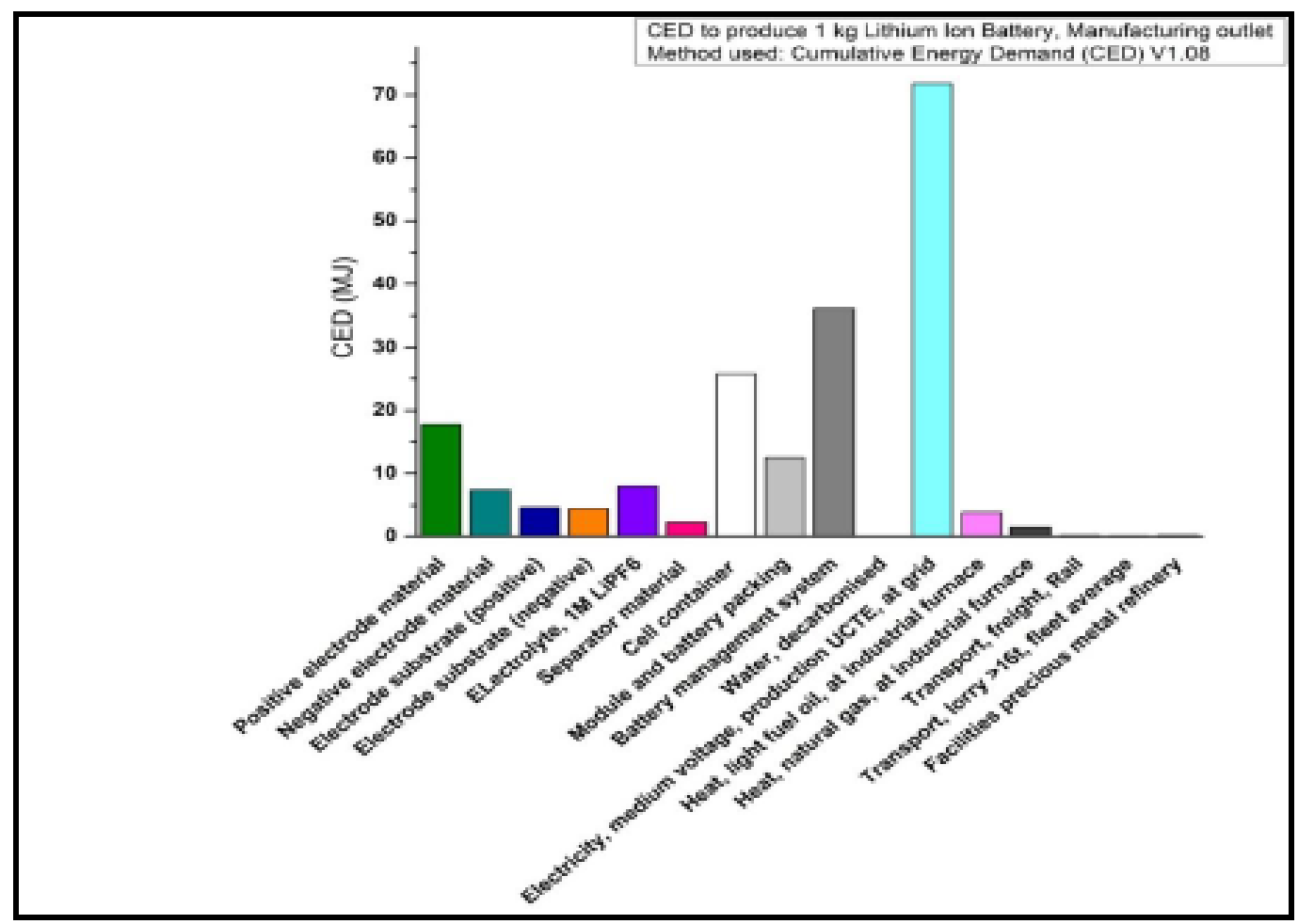

Figure 3.5 - CED impacts of the major processes during the cradle-to-gate stage of Lithium Ion battery life cycle.

Source: Hiremath M., 2014. 


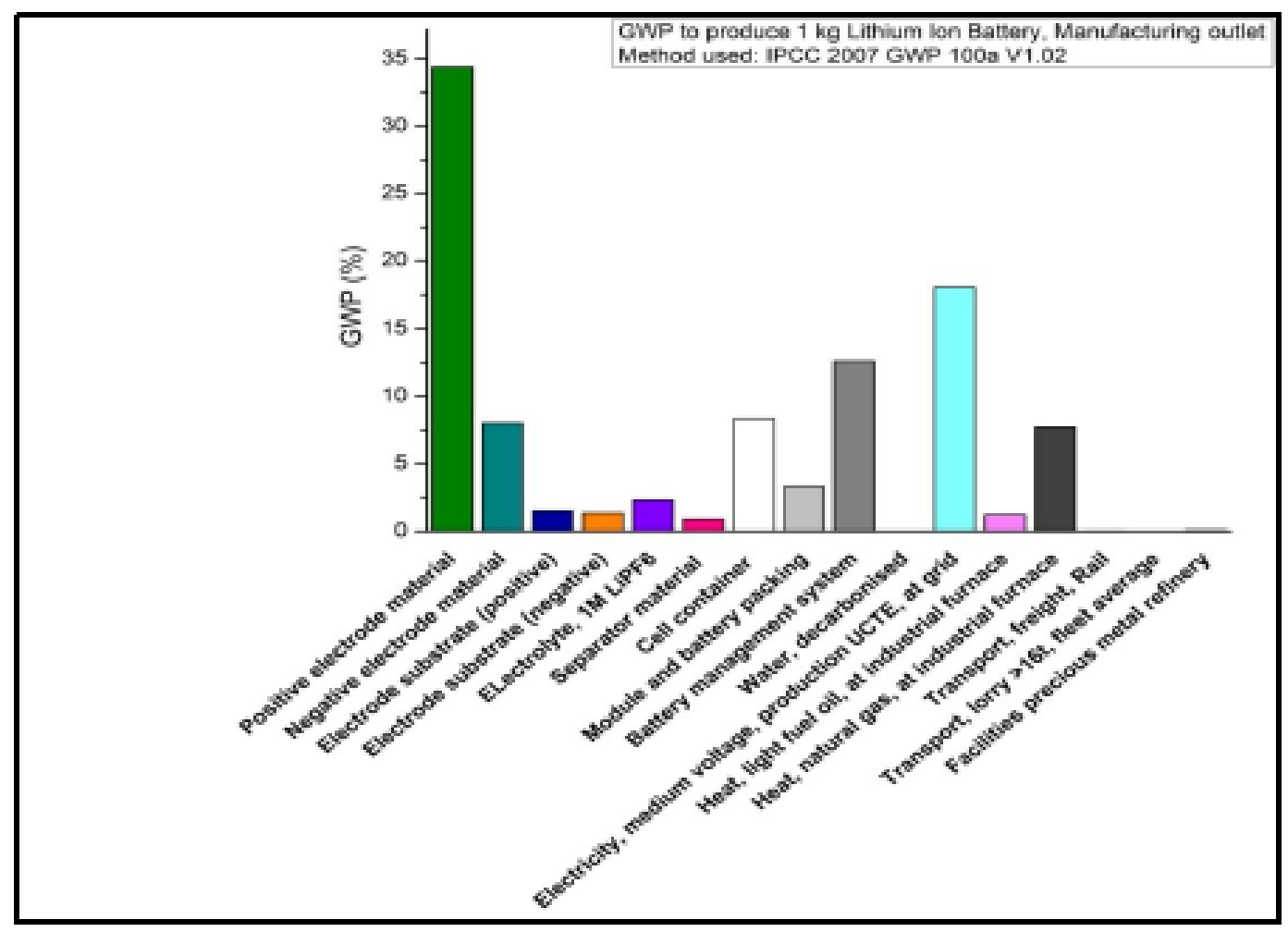

Figure 3.6 - GWP impacts of the major processes during the cradle-to-gate stage of Lithium lon battery life cycle

Source: Hiremath M., 2014.

Furthermore, in addition to the two impact categories presented, Hiremath used ReCiPe 2008 methodology to describe the impact of the Li-ion battery 17 midpoint indicators, where the following cradle-to-gate processes have shown the biggest influence on these indicators, Figure 3.7. 


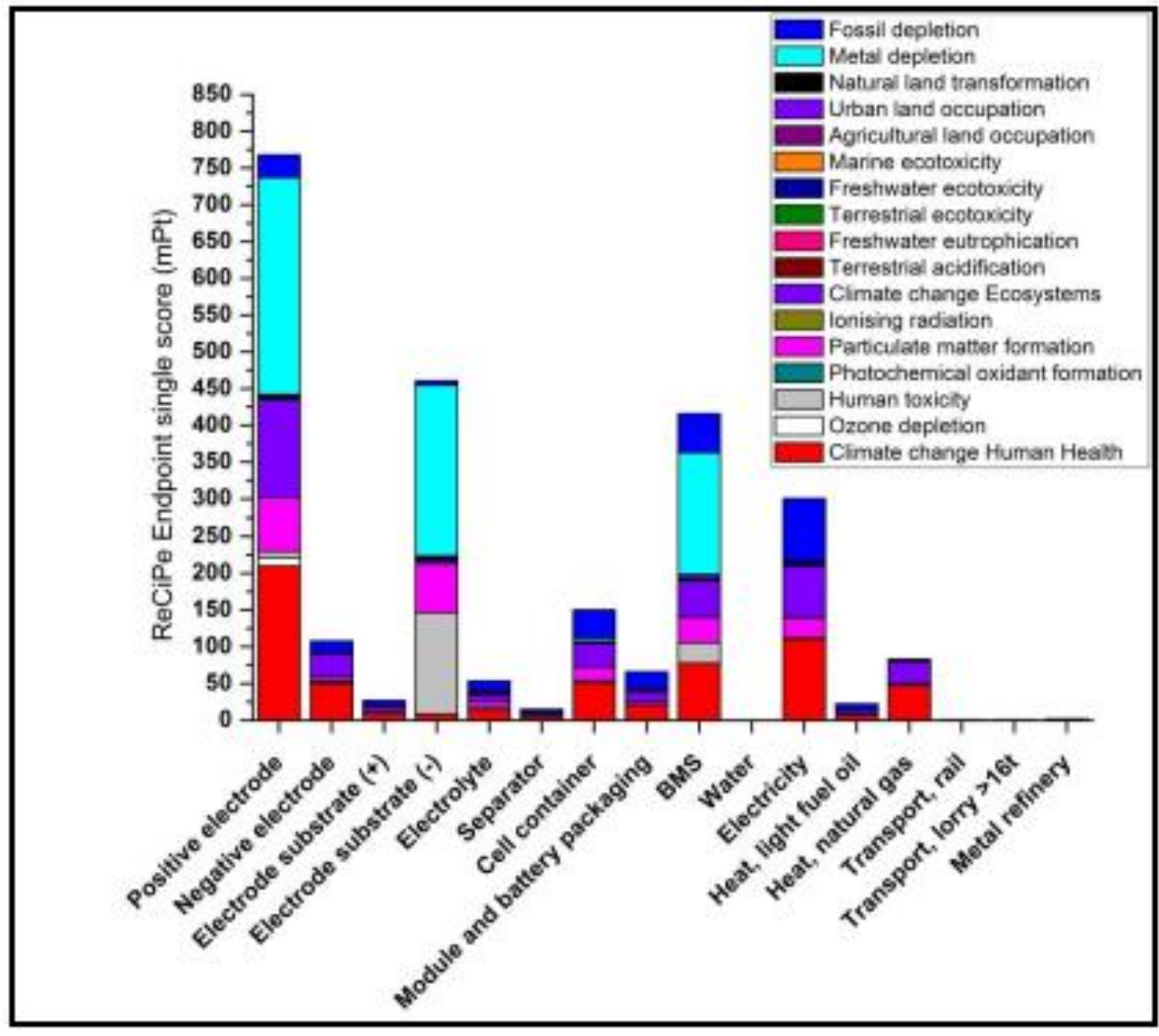

Figure 3.7 - ReCiPe 2008 single point score for Lithium lon cradle-togate processes that adversely impact the environment.

Source: Hiremath M., 2014.

According to the results shown in Figure 3.7, the cathode has the highest influence on the overall environmental impact of the Li-ion battery, and therefore it should be focus of further researches, in order to achieve more efficient cathode technologies. It can also be observed that the main mid-point indicators affected by Li-ion production chain, from life cycle perspective, are climate change (human health and ecosystems), fossil depletion and metal depletion.

As seen in all three previous figures, the environmental impact caused by the energy needed for producing the battery is considerably high. Thus, since lithium extraction is very energy intensive as well as the battery production, it can be said that there is a need to explore alternative ways of its manufacture, and its use on larger scale should be carefully planed and studied in order to make sure it is a good option environmentally speaking. Lastly, another fact that should be mentioned is that some of the materials used on some kinds of Li-ion batteries, such as cobalt, have supply constraints that may put into question the feasibility of a large-scale production (Andersson and Rade, 2001 and Gaines and Nelson, 2009). 


\section{METHODOLOGICAL FRAMEWORK}

This chapter defines the methodological framework of the present study. The methodology used follows the basic steps of a Life Cycle Assessment analyzes established by ISO 14040, as already defined on chapter 2. As previously mentioned, this work intends to support BS Energy on the decision of whether to invest on an energy storage system, for charging electrical vehicles, according to its environmental impact, when compared with the use of energy from the grid. The storage system would be fed with solar power, which can also feed the cars directly.

More specifically, the system that is being analyzed is a storage system for the recharging of 5 electrical cars. It consists of a stationary battery that is fed with energy from a photovoltaic power generation, and also with energy from the grid when needed. If the storage can't meet the energy demand, energy from the grid can also feed the fleets directly, as demonstrated in Figure 4.1. For the LCA study it is assumed that, at the end of life from the battery system and the photovoltaic panel, the elements can be recycled.

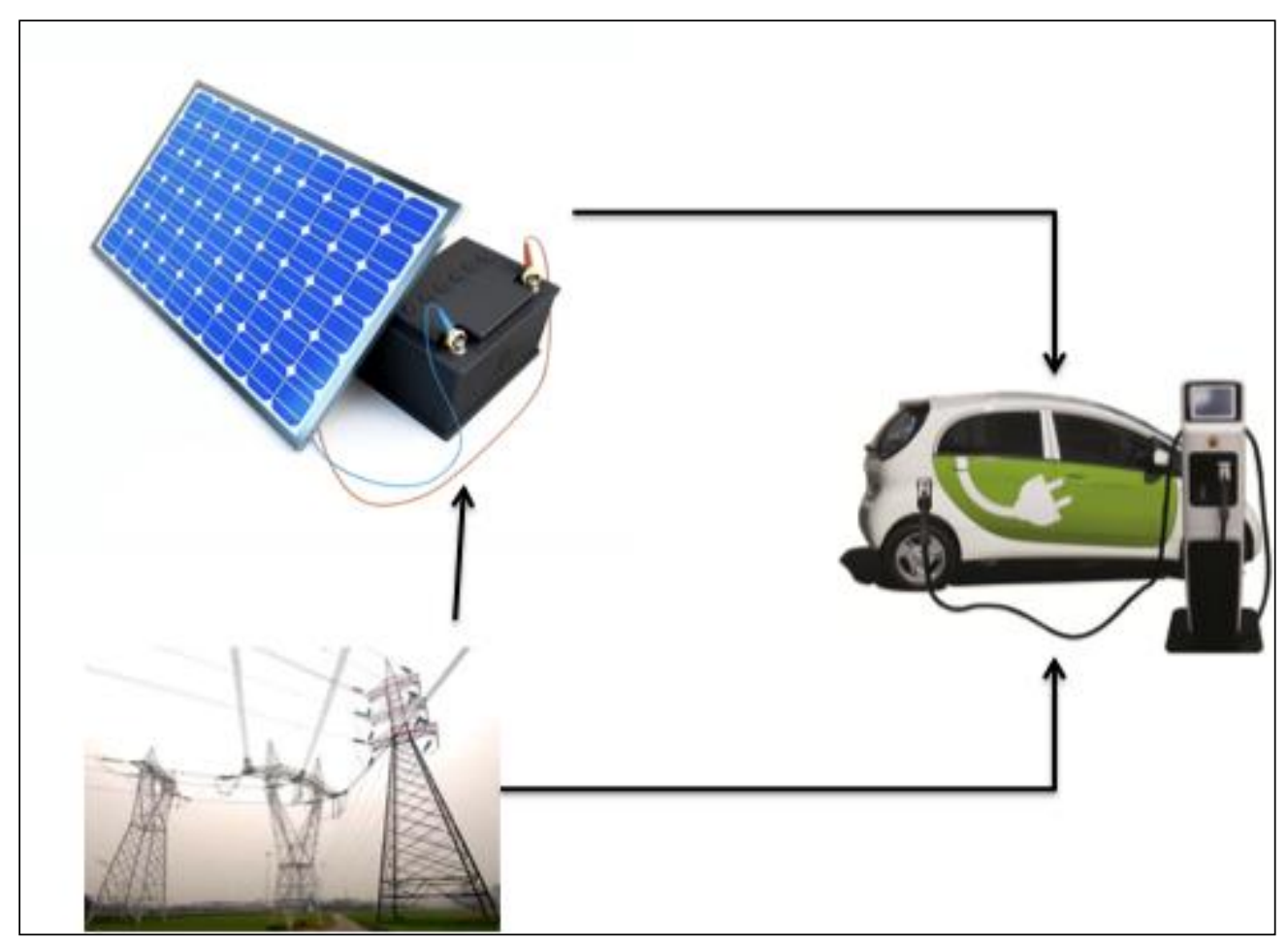

Figure 4.1 - Scheme of the system studied 
The time period considered on the study is 1 year. Therefore, the functional unit of the LCA is defined as the amount of energy needed to charge 5 electric vehicles in one year. The period of one year was chosen in order to comprehend the months of high and low solar power generation. For the comparison with the energy from the grid it will be considered the average of the different types of energy produced in Germany during the year.

After the analysis we expect to obtain the period when the use of the battery and the energy from the grid are equal in terms of emissions, and thus, to know how long the battery needs to be used in order to have a lower impact than the grid. This notion is represented by the graph bellow (Figure 4.2).

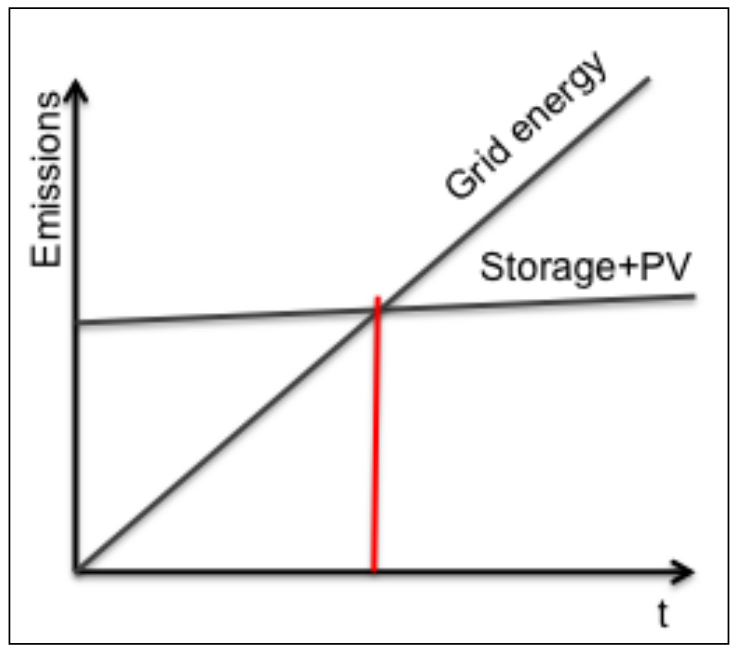

Figure 4.2 - Relation between the impact of using the storage system and the energy from the grid

The environmental impact of both systems is analyzed trough the software Umberto $\mathrm{Nxt}^{1}$. Besides all the data provided by BS-Energy and by open sources, we use the Ecoinvent database, version 3, for its status as world leader life cycle inventory data source.

1 Umberto Nxt is a German tool for performing life cycle assessment with graohical modeling. The software supports many different LCA methods, such as: ReCiPe, Impact 2002+, Ecoindicator99, IPCC, among others. 
For the charging station model we the production of the battery, the production of the PV panel, and the production of the local energy as demonstrated on Figure 4.3.

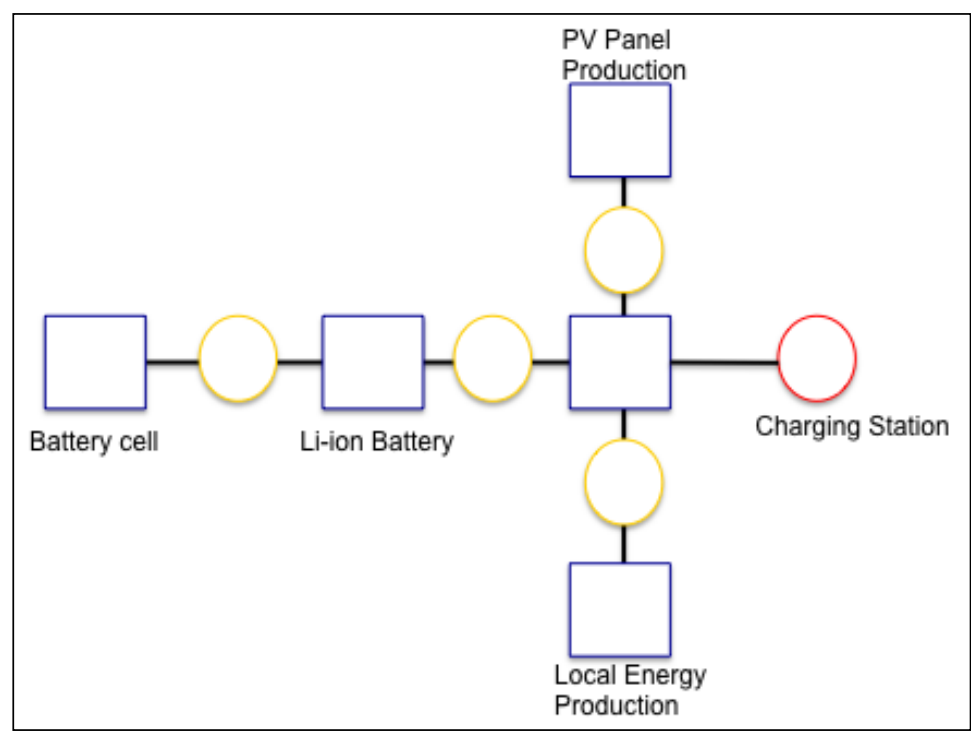

Figure 4.3 - Draft of the LCA model for the charging station

Since the vehicles could also be charged only by the PV system or by the grid, a separated calculation for the generation of the solar energy and the energy from the grid is also made, in order to enable a comparison between the different systems.

\subsection{LCA of the Storage System}

For the present study, the considered battery is a stationary battery used to store energy generated by a photovoltaic system. The system boundaries, which are defined as: "set of criteria specifying which unit processes are part of a product system" (ISO 14040), including the processes examined in the study, are as follows (Figure 4.4):

- Battery manufacturing step, including raw material supply, manufacturing/assembly of the main components and final waste treatment, with the waste representing the raw material from the battery and the packaging;

- The transportation of the battery to the end user; 
- Operation step, including the production of electricity used by the battery during its useful life and the manufacturing of the photovoltaic system;

- Transportation of the waste to the disposal site (End-of-life step).

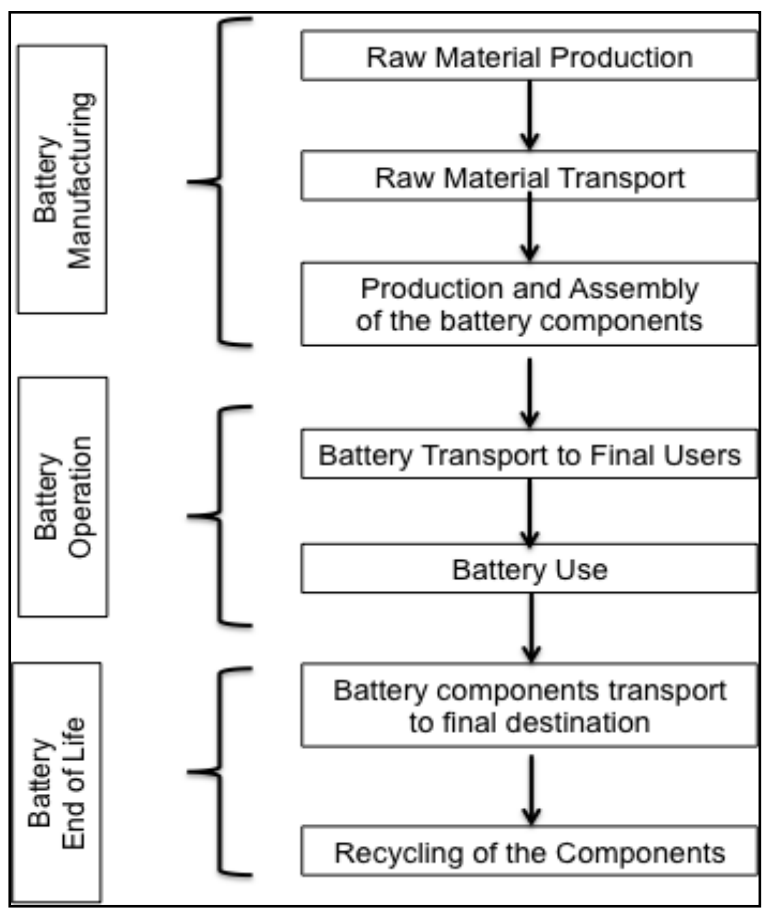

Figure 4.4 - Battery System boundaries

In order to meet the objectives of the present work, the eco-profiles of materials and energy sources used to produce the battery and the impacts related to the transportation step and to the end-of-life processes of packaging materials are based on the Ecoinvent database.

The profile of the battery is given by BS-Energy, which provides the following information:

- Type of chemistry of the battery;

- Size of the battery;

- Location;

- Logistics for the transportation of the battery;

- Need of extra construction for the station;

- Amount of computers that will serve the station;

- Efficiency of the battery; 
- Number of cars that will be using the station;

- The amount of energy from the grid that will be needed; and

- The amount of solar energy that is locally generated.

\subsection{LCA Solar Energy Generation}

For the LCA analyses of the solar energy production by BS Energy the following parameters are considered:

- What kind of technology for solar energy production is used;

- Size of the system;

- The location of the system;

- he amount of energy produced;

- The uses given for the energy produced;

- The maintenance of the system;

- The frequency of which the solar panels must be changed;

- The amount of insolation that the region gets around the year;

- The periods of the year with higher solar energy production

The process data includes quartz reduction, silicon purification, wafer, panel and laminate production, supporting structure and dismantling. The operational lifetime is assumed as being 30 years. Transports of materials, energy carriers, semi-finished products and the complete power plant, and waste treatment processes for production wastes and end of life wastes hall also considered, as well as air- and waterborne process-specific pollutants.

Afterwards, the environmental impact of the local storage and local solar energy generation are compared with the environmental impact of using the energy from the grid. The kind of energy produced in the country, the periods of most energy production and most energy consumption, as well as the user's typical behavior are considered in the analyses. 


\section{CASE STUDY - BS ENERGY}

BS Energy (Braunschweiger Versorgungs-AG \& Co. KG) is a German energy and drinking water distributor from the city of Braunschweig. In order to meet the growing worldwide demand for a cleaner supply chain, the company has been expanding its business investing on new clean technologies such as electrical cars and different types of renewable energy. This chapter presents and analyzes one of BS Energy's initiatives towards sustainable development.

BS Energy currently owns a 25 electrical car fleet, which has also been used for research in partnership with the TU Braunschweig. Seeking to improve the energy efficiency of its fleet and reduce its environmental impact, BS Energy has been increasingly investing in research and on new technologies that could contribute to minimize its environmental footprint. As a result, the company intends to invest on a stationary battery, which is a lithium titanate battery (LTO) that stores energy from a PV system installed on the top of a bicycle parking situated in the company area, to charge 5 of its 25 vehicles.

This case study aims to analyze the environmental feasibility of this project, that is, to understand whether it is environmentally preferable to use the energy storage system or if the best option is to use only the power network.

\subsection{Goal and Scope Definition}

The battery in question is a stationary battery with approximately $0.3 \mathrm{~m}^{3}$, a weight of $160 \mathrm{Kg}$ and total capacity of $8 \mathrm{KWh}$, which represents approximately $50 \mathrm{Km}$ of energy equivalent and its total cost is 40.000 euros. The battery will be powered by a photovoltaic (PV) system, which has an approximate area of $30 \mathrm{~m}^{2}$ of solar panel, with a $10 \mathrm{KW}$ power generation capacity.

The main goal of this work is to make a LCA analysis of the future charging system of BS Energy in order to support the decision of the company about whether it is environmentally worthy to build it or if it is better to keep using the energy provided from the grid. While not the focus of this study, in a further analysis it would also be interesting to consider the economic viability of the system. 
As mentioned on chapter 4, since the functional Unit of this LCA was defined as the amount of energy needed to charge 5 electric vehicles in one year. For comparative purposes and to obtain consistent results, six different scenarios are analyzed. First, all the scenarios are presented separately, and by the end of the chapter a graphic comparison of all 6 different scenarios is made in order to make the results more clear.

The first scenario considers only the use of the energy from the grid, which means no local renewable generation and no storage system. The two following scenarios consider only the use of the PV system, with no storage, one considering maximum use of the solar energy produced, which is enough for charging 3 vehicles and the 2 remaining would be charged by the grid, and the second considering that some of the solar energy produced will be lost and, thus, only two vehicles would be charged by the PV system.

Finally, the three last scenarios consider the use of the storage system, which can store enough energy from the PV system for charging one vehicle, and, therefore, the rest of the solar energy produced could charge another two vehicles, considering that by having the battery the loss of solar energy would be smaller. Here the differences in scenarios occur by the fact that the battery can have different lifetime periods, according to many factors, such as temperature and use. The most conservative scenario considers the most common Li-ion battery, which has a graphite anode and lifetime of 5 years. Second, it is considered the lowest lifetime period for a lithium titanate battery, which is 10 years. And lastly, it is considered the maximum lifetime period of a lithium titanate battery, which corresponds to 15 years. On all three scenarios the German electricity net will necessarily charge 2 vehicles.

\subsection{Environmental Impact Assessment}

In accordance with the recommendations of ISO 14040, this work considers five impact categories:

- Global warming potential;

- Ozone depletion potential;

- Photochemical smog potential; 
- Acidification potential; and

- Eutrophication potential.

There are a few disadvantages in considering so many different impact categories. The biggest one is the fact that most times one technical solution can be better on regard of one impact category but not the other. It is hard to find the ideal solution for all of them. And, assuming that not all of them will be mitigated, it is not always simple to determine which one should be valued the most.

There are no generally acceptable methods that can put all the impact categories on one single result. Therefore, it is important to consider each case according to the biggest environmental problems of each location. The five impact categories mentioned will be analyzed for each one of the scenarios studied on this work, namely:

- BS Energy cars being charged directly from solar energy locally generated;

- Cars being charged by the stationary battery, which stores energy from the solar panels;

- Cars being charged directly with energy from the German grid.

This comparison will enable us to make a support for the decision of whether it is environmentally worthy to use the battery and to generate solar energy locally or if using just the energy from the grid would have a lower environmental impact.

\subsection{Scenario 1 - Use of Energy from the Grid}

For the calculation of the LCA using the energy from the grid, we utilized the ecoinvent database 3 (v3.1), and considered both the processes for electricity generation, high and medium voltage. Both processes include also the imports and exports of energy in Germany.

The observed time period for the energy mix is from 2008 to 2014 (last update on 2014/04/14). The process includes electricity produced in the country, imports, transmission over aerial lines and cables, direct emissions to air, and all the electricity losses during transmission. Notice that losses during the 
transformation are not included. Electricity losses during distribution were assumed as 4\% (World Bank, 2014).

As already mentioned on the section 2.4.1, the renewable energy generation in Germany has been suffering a significant annual increase, which leads to a cleaner energy mix. 2014 was the first year in history that the renewables were the largest energy source in Germany, representing $25.8 \%$ of the energy mix followed by the lignite (brown coal), which detains $25.6 \%$ of the energy mix (AG Energiebilanzen 2014). However, brown and hard coal still have a big share on the energy mix, and together they represent $43.6 \%$ of the energy mix, as shown on Figures 5.1 and 5.2.

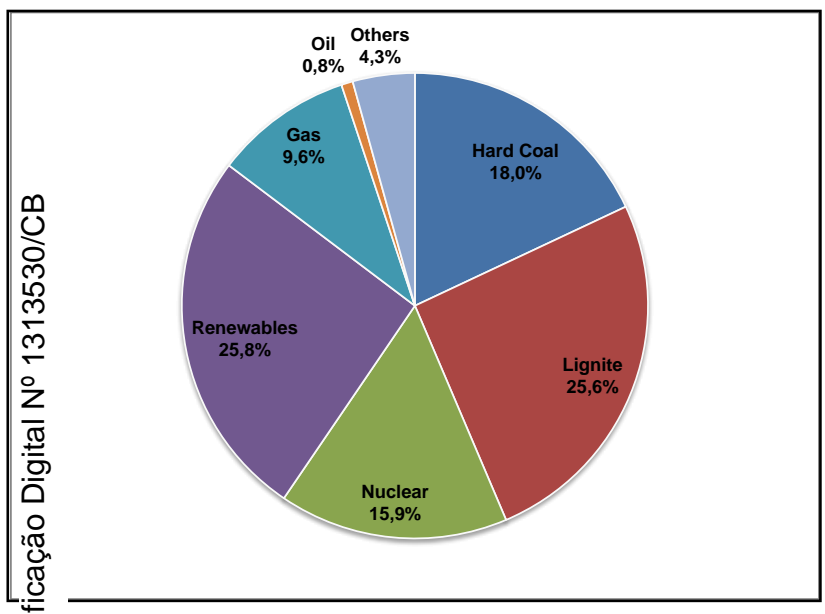

ure 5.1 - Energy sources share in gross power Iduction in 2014

rce: AG Energiebilanzen, 2014

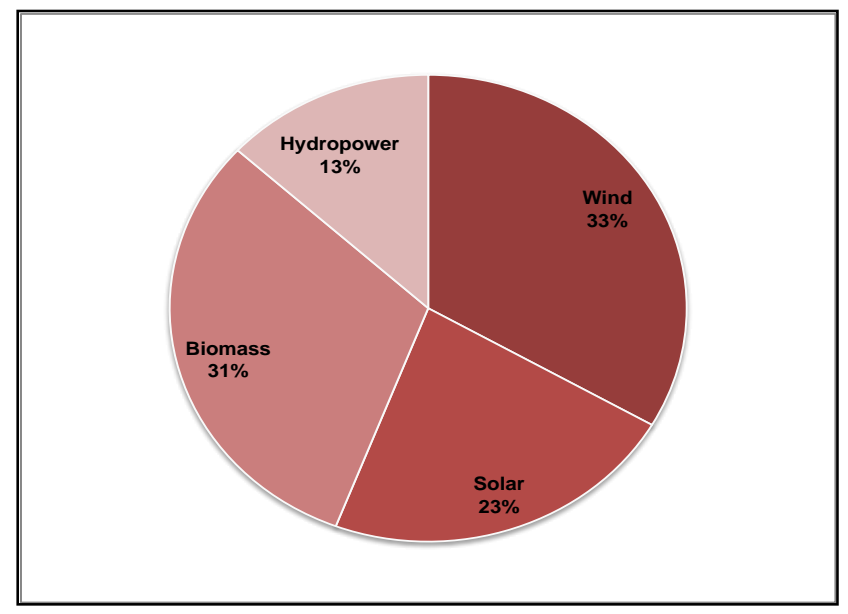

Figure 5.2 - Renewables share in gross power production in 2014

Source: AG Energiebilanzen, 2014.

The high share of coal usage in the electricity mix has been keeping emissions at a high level. As calculated with the software Umberto Nxt, the GWP potential, considering the current German energy mix, for providing enough energy for charging the 5 cars corresponds to $9.470 \mathrm{~kg} \mathrm{CO} 2-\mathrm{Eq}$.

Even though the production of renewables is expected to keep growing considerably, and power production from nuclear sources to decline by $7-8 \%$, due to the shutdown of the nuclear plant at Grafenrheinfeld in spring 2015, the expectations is that power production from lignite will remain stable in 2015, which means that it will remain high. 


\subsubsection{Results}

In this section we consider the impact of charging all the vehicles just using the German electricity net. Losses during transmission are also taken into account. According to the World Bank data, 2014, the losses during electricity distribution in Germany, including losses between supply and distribution points and from the distribution points to consumers, is $4 \%$, one of the lowest on the world.

\section{Global Warming Potential}

The global warming potential for charging one vehicle using the German electricity net was calculated as $1.890 \mathrm{~kg} \mathrm{CO} 2$-Eq. Considering $4 \%$ of distribution losses, this value would increase up to $1.970 \mathrm{~kg} \mathrm{CO} 2-\mathrm{Eq}$. Thus, if the grid the GWP charged all the 5 vehicles would correspond to $9.830 \mathrm{~kg} \mathrm{CO} 2-\mathrm{Eq}$.

\section{Ozone depletion}

When using the energy from the grid for charging one of the electrical vehicles, the ozone depletion potential corresponds to $15 \times 10^{-5} \mathrm{Kg} \mathrm{CFC}^{-11}$-Eq. Including distribution losses this value increases to $16 \times 10^{-5} \mathrm{Kg} \mathrm{CFC}^{-1} 11-\mathrm{Eq}$. Considering that 5 vehicles are charged by the grid, the ozone depletion potential would be $80 \times 10^{-5} \mathrm{Kg} \mathrm{CFC}^{-11}-\mathrm{Eq}$.

\section{Photochemical smog}

Charging one car with energy from the grid implies a photochemical smog potential of $2.03 \mathrm{Kg}$ MNVOC, $2.11 \mathrm{Kg}$ MNVOC when distribution losses are included. Therefore, the photochemical smog potential for charging 5 vehicles would be of approximately $10.60 \mathrm{Kg}$ MNVOC.

\section{Acidification}

The acidification potential for charging one vehicle using the German electricity net is $2,63 \mathrm{~kg} \mathrm{SO} 2-\mathrm{Eq}, 2.73 \mathrm{~kg} \mathrm{SO} 2-\mathrm{Eq}$ including distribution losses. Thus, the acidification potential for charging 5 cars using the same system is $13.70 \mathrm{~kg} \mathrm{SO} 2-\mathrm{Eq}$. 


\section{Eutrophication}

The marine eutrophication potential for charging one vehicle with energy from the grid is $0.19 \mathrm{~kg} \mathrm{~N}-\mathrm{Eq}$, including $4 \%$ distribution losses the value increases to $0.20 \mathrm{~kg} \mathrm{~N}$-Eq. Therefore, charging 5 vehicles using the German electricity net implies a marine eutrophication potential of $1 \mathrm{~kg} \mathrm{~N}$-Eq.

Finally, considering that the one vehicle would be charged by the grid, which implies a freshwater eutrophication potential of $0.24 \mathrm{~kg} \mathrm{P-Eq,} 0.25 \mathrm{~kg}$ P-Eq including distribution losses, the total freshwater eutrophication potential for charging 5 cars would be $1.25 \mathrm{~kg}$ P-Eq.

\subsection{Scenarios 2 and 3 - BS Energy Solar energy generation}

In this section the PV system that is being constructed by BS Energy is detailed and analyzed from the environmental point of view.

The PV system consists of a $30 \mathrm{~m}^{2}$ multi silicon solar panel with a $10 \mathrm{KW}$ power generation capacity. The PV system will feed the stationary battery and will also be able to charge the cars directly when necessary.

Since the time period considered on the study is 1 year of vehicle usage, and the solar panel life time is approximately 30 years, the environmental impact of the solar panel calculated on the software Umberto Nxt was divided by 30, in order to have consistent results.

One year of the vehicle fleet usage is equivalent to approximately 90.000 $\mathrm{Km}$, considering that each car travels approximately $50 \mathrm{Km}$ a day, and the fleet being fed by the system consists of 5 vehicles. Knowing that each vehicle, traveling $50 \mathrm{Km}$ a day, would consume about $2.880 \mathrm{KWh}$ a year, the total energy need for the year corresponds to $14.400 \mathrm{KWh}$.

\subsubsection{LCA Data}

For the LCA calculation for the PV system, a similar PV system in Braunschweig was found in order to obtain information about the solar energy production in the city with a $10 \mathrm{KW}$ power PV system. This PV system has 10,56KWp. Data about its production was available for the period from 2011- 
2014. An average for those years was taken, and the scenarios for the periods with higher and lower generation were also taken into consideration, as seen on Table 5.1 .

Table 5.1 - Solar energy production from a 10,56KW PV System in Braunschweig

\begin{tabular}{|c|c|c|c|c}
\hline Year & $\begin{array}{c}\text { Total Generation } \\
\text { (MWh) }\end{array}$ & $\begin{array}{c}\text { Monthly Average } \\
\text { Production (KWh) }\end{array}$ & $\begin{array}{c}\text { Average Oct-Feb } \\
\text { (KWh) }\end{array}$ & $\begin{array}{c}\text { Average Mar-Sept } \\
\text { (KWh) }\end{array}$ \\
\hline $\mathbf{2 0 1 1}$ & 8,87 & 739 & 252 & 1.087 \\
\hline $\mathbf{2 0 1 2}$ & 10 & 840 & 427 & 1.134 \\
\hline $\mathbf{2 0 1 3}$ & 9,44 & 787 & 335 & 1.109 \\
\hline $\mathbf{2 0 1 4}$ & 9,62 & 802 & 399 & 1.090 \\
\hline $\begin{array}{c}\text { Total } \\
\text { Average }\end{array}$ & 9,48 & 792 & 353 & 1105 \\
\hline
\end{tabular}

Source: Sunny Places, 2015.

Since the time period considered on this study is of one year, we consider the total average production for one year, which is $9.48 \mathrm{MWh}$. The Chart 5.4.1 bellow shows the monthly production during 2014, illustrating the big difference in generation between summer and winter.

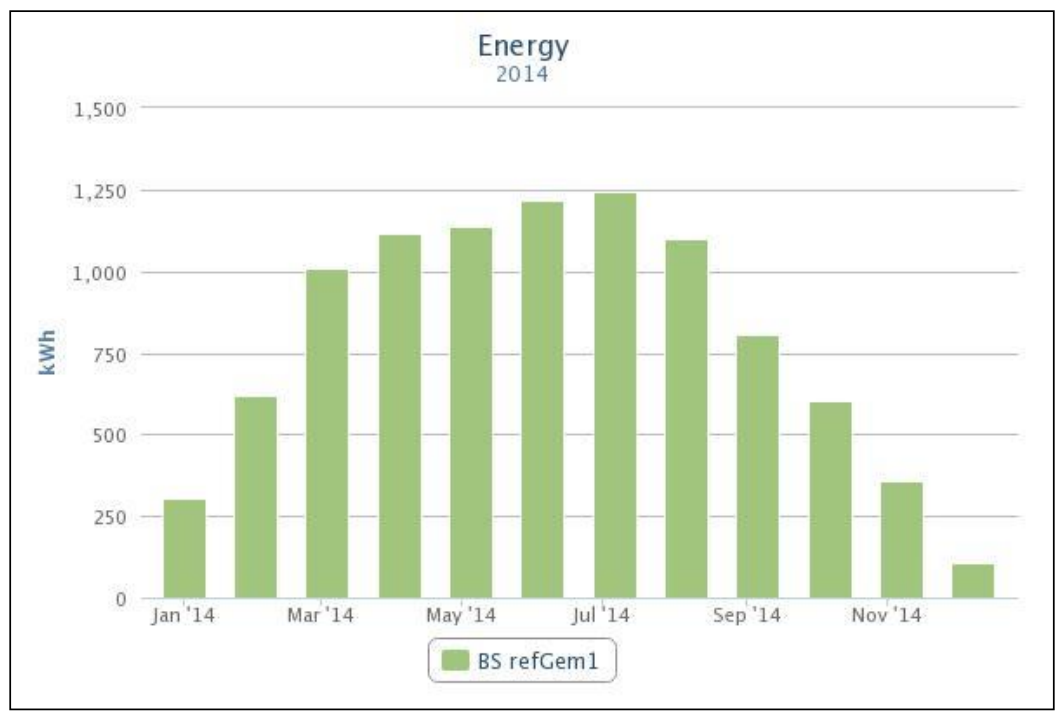

Figure 5.3- Solar energy generated in by a $10 \mathrm{KWp}$ panel in Braunschweig during 2014

Source: Sunny Places, 2015.

The LCA calculation for the PV system was based on the following data:

- Type of solar panel: multi silicon;

- Time period of one year; 
- Average electricity generated during one year is $9.480 \mathrm{KWh}$;

- Size of the solar panel for the calculation, considering the life time of 30 years, was $1 \mathrm{~m}^{2}$; and

- Umberto process: market for photovoltaic panel multi-Si wafer, global.

\subsubsection{Results}

For the results of the environmental impact of the PV system it was considered that the cars are being charged straight by the solar energy generated locally, which provides on average $9.480 \mathrm{KWh}$ energy per year, with no storage. This much energy is enough to charge 3 of the 5 cars that should be charged by the system. Therefore, energy from the grid would be needed to charge the other 2 vehicles.

Each vehicle consumes approximately $2.880 \mathrm{KWh}$ per year, considering that they would drive $50 \mathrm{Km}$ per day. Thus, the solar panel could provide enough energy for 3 vehicles with a surplus of $840 \mathrm{KWh}$ per year. Considering that there wouldn't be storage in this first scenario, lost energy must be taken into account. If the system is optimized in a way that the cars are charged during the period of the day when the solar energy is being produced, it could be possible to have the 3 vehicles charged by the solar panel, with the minimum loss of $840 \mathrm{KWh}$. If for some reason the some cars are charged during the night, the solar energy lost would be higher, and therefore it could be considering that it would charge only 2 vehicles a day. These scenarios were calculated and are described separately, according to each one of the impact categories previously mentioned.

\section{Global warming potential (GWP)}

The global warming potential of the PV System, providing energy for 3 cars, is $211 \mathrm{Kg} \mathrm{CO}_{2}$ eq. The GWP of the energy provided from the grid to charge 1 vehicle corresponds to $1.970 \mathrm{Kg} \mathrm{CO}_{2} \mathrm{eq}$, and therefore to charge 2 vehicles corresponds to $3.940 \mathrm{Kg} \mathrm{CO}_{2}$ eq. That means the total GWP using the PV system and the energy from the grid for the charge of the 5 cars is $4.150 \mathrm{Kg} \mathrm{CO}_{2} \mathrm{eq}$. 
In a worse scenario, considering losses from solar energy due to the nonstorage, it can be assumed that 2 vehicles would be charged with solar energy and 3 with energy from the grid, giving a GWP of $6.050 \mathrm{Kg} \mathrm{CO}_{2}$ eq.

\section{Ozone depletion}

The ozone depletion for the PV system corresponds to $4.9 \times 10^{-5} \mathrm{~kg}$ CFC11-Eq and for the energy from the grid (considering the charge of 2 cars) corresponds to $32 \times 10^{-5} \mathrm{~kg} \mathrm{CFC}-11-\mathrm{Eq}$. The total impact is $36.9 \times 10^{-5} \mathrm{~kg} \mathrm{CFC}-11$ Eq. If only two vehicles were charged by the PV system, the ozone depletion potential would be $51.30 \times 10^{-5} \mathrm{~kg}$ CFC-11-Eq.

\section{Photochemical smog}

The photochemical smog potential for the charge of 3 cars with the PV system is $0.90 \mathrm{~kg} \mathrm{NMVOC}$, and for the charge of 2 cars with energy from the grid is $4.22 \mathrm{~kg}$ NMVOC. Therefore, the total impact would be of $5.12 \mathrm{~kg}$ NMVOC. If the grid charged 3 vehicles the total photochemical smog would be $6.93 \mathrm{~kg}$ NMVOC. It can be noticed that here the impact of the PV system is very low when compared with the impact of the use of energy from the grid.

\section{Acidification}

The acidification potential for charging 3 vehicles by the PV system corresponds to $1.24 \mathrm{~kg} \mathrm{SO} 2-\mathrm{Eq}$ while the acidification potential for charging the 2 reaming vehicles with energy from the grid corresponds to 5,46 kg SO2-Eq. Thus, the total acidification potential considering the use of the PV system complemented by the grid is $6.70 \mathrm{~kg} \mathrm{SO} 2-\mathrm{Eq}$. When having 3 cars being charged by the grid the total potential would go up to $9.02 \mathrm{~kg} \mathrm{SO} 2-\mathrm{Eq}$.

\section{Eutrophication}

For the case studied, the marine eutrophication potential in regard of the use of the PV system for charging 3 cars during one year corresponds to $0.07 \mathrm{~kg}$ $\mathrm{N}-\mathrm{Eq}$, while the eutrophication potential for charging two vehicles with energy from the grid corresponds to $0.40 \mathrm{~kg} \mathrm{~N}$-Eq. Thus, the total marine eutrophication potential for this case is $0.47 \mathrm{~kg} \mathrm{~N}$-Eq. If the share of cars being charged by the grid increased by one vehicle, the value would increase up to $0.64 \mathrm{~kg} \mathrm{~N}$-Eq. 
The freshwater eutrophication potential for charging 3 vehicles using the PV system is $0.02 \mathrm{~kg}$ P-Eq. The freshwater eutrophication potential for charging the two remain vehicles with energy from the grid is equal to $0.50 \mathrm{~kg} \mathrm{P}-\mathrm{Eq}$, giving a total freshwater eutrophication potential of $0.52 \mathrm{~kg}$ P-Eq. In case of 2 vehicles being charged by the PV system and 3 by the grid the total freshwater eutrophication potential would be $0.76 \mathrm{~kg}$ P-Eq.

\subsection{Scenarios 4, 5 and 6 - Stationary Battery}

In this section the battery composition will be detailed, and the parameters for its modeling will be described. It is important to notice here that the battery will be bought from the German company ACTIA GmbH, and it is not part of this work to modify the battery components according to what can might be found as being better technology. However, at the conclusions improvements can be suggested.

As mentioned on the topic 5.1, the battery that BS Energy intends to buy is lithium-titanate battery, referred to as LTO in the battery industry, which is a lithium battery with an anode composition of Li4Ti5O12. Due to its advanced Nano-technology, the LTO has many advantages when compared to other lithium batteries, such as (Bingbing Tian et al, 2010; Michael R. Giuliano et al., 2011):

- It has the ability to operate on a wide temperature range $\left(-30-55^{\circ} \mathrm{C}\right)$;

- The recharge efficiency exceeds $98 \%$, when compared to carbon based batteries;

- Li-Titanate batteries have a long cycle life: between 2000 and 7000 cycles at $100 \%$ depth-of-discharge;

- Life expectancy ranges between 10 and 15 years;

- High security and stability;

- It is charged fast; and

- Li-Titanate batteries are eco-friendly.

One disadvantage is its lower inherent voltage, around $2.4 \mathrm{~V} / \mathrm{cell}$, which means a lower energy density when compared to other lithium batteries. But, if compared to some non-lithium batteries, such as acid batteries, the LTO has a 
higher energy density. To illustrate the differences between battery technologies, Table 5.2 shows a comparison made by the study from Nelson and Amine (2010).

\begin{tabular}{|c|c|c|c|c|c|}
\hline System & $\begin{array}{c}\text { NCA- } \\
\text { Graphite }\end{array}$ & $\begin{array}{c}\text { LFP- } \\
\text { Graphite }\end{array}$ & $\begin{array}{l}\text { MS- } \\
\text { TiO }\end{array}$ & $\begin{array}{l}\text { MNS- } \\
\text { TiO }\end{array}$ & $\begin{array}{c}\text { MN- } \\
\text { Graphite }\end{array}$ \\
\hline $\begin{array}{l}\text { Electrodes } \\
\text { Positive } \\
\text { Negative }\end{array}$ & $\begin{array}{l}\text { LiNi0.8Co0.1 } \\
\text { 5A10.05O2 } \\
\text { Graphite }\end{array}$ & $\begin{array}{l}\text { LiFePO4 } \\
\text { Graphite }\end{array}$ & \begin{tabular}{|l|} 
LiMn2O4 \\
Li4Ti5O12
\end{tabular} & $\begin{array}{l}\text { LiMn1.5Ni0 } \\
.5 \mathrm{O} 4 \\
\mathrm{Li} 4 \mathrm{Ti} 5 \mathrm{O} 12\end{array}$ & $\begin{array}{l}\text { Li1.2Mn0.6N } \\
\text { i0.2O2 } \\
\text { Graphite }\end{array}$ \\
\hline $\begin{array}{l}\text { Capacity, } \\
\mathrm{mAh} / \mathrm{g} \\
\text { Positive } \\
\text { Negative }\end{array}$ & $\begin{array}{l}155 \\
290\end{array}$ & $\begin{array}{l}162 \\
290\end{array}$ & $\begin{array}{l}100 \\
170\end{array}$ & $\begin{array}{l}130 \\
170\end{array}$ & $\begin{array}{l}275 \\
290\end{array}$ \\
\hline $\begin{array}{l}\text { Voltage, } 50 \% \\
\text { SOC }\end{array}$ & 3.6 & 3.35 & 2.52 & 3.14 & 3.9 \\
\hline $\begin{array}{l}\text { ASI for } 10-\mathrm{s} \\
\text { Pulse, ohm-cm }\end{array}$ & 25 & 25 & 9.2 & 100 & 25 \\
\hline Safety & Fair & Good & Excellent & Excellent & Excellent \\
\hline Life Potential & Good & Good & Excellent & Unknown & Unknown \\
\hline Cost & Moderate & Moderate & Low & Moderate & Moderate \\
\hline Status & Pilot Scale & Pilot Scale & Develop. & Research & Research \\
\hline
\end{tabular}

Table 5.2 - Comparison between different Li-ion batteries

Source: Paul Nelson and Kahlil Amine, 2010.

Due to its many benefits, especially high security and high stability, LTO batteries have a wide range of applications, such as in the aerospace and military industries, for electric vehicles and home storage.

However, for technical reasons it is necessary to use the graphite anode $\left(\mathrm{LiC}_{6}\right)$ in the calculation of the LCA. This probably needs to worse results for the charging station regarding environmental issues. Therefore, after the calculation it is necessary that assumptions are made on the difference between the two anodes, based on the available literature.

Figure 5.4 shows a simplified scheme of the battery cell, which components and phases of its life cycle are detailed on the following topics. 


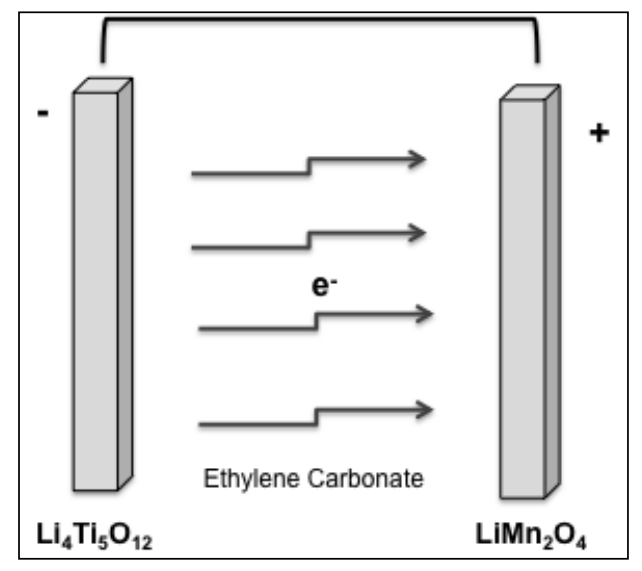

Figure 5.4 - Scheme of a cell of the stationary battery

\section{Cathode}

As previously mentioned a battery cathode can be made of different materials. In this specific case the cathode was made of $\mathrm{LiMn}_{2} \mathrm{O}_{4}$. This type of cathode is largely used in batteries due to its high thermal stability, low cost, raw material abundance and environmental affinity. The biggest disadvantage of the $\mathrm{LiMn}_{2} \mathrm{O}_{4}$ is that the manganese suffers surface dissolution in the electrolyte at high temperatures (Ulsan National Institute of Science and Technology, 2014).

\section{Anode}

Li-ion batteries anodes are typically made of graphite. The battery in this specific case has an anode composed of $\mathrm{LiTi}_{5} \mathrm{O}_{12}$. However, as already mentioned, the LCA calculation was made considering a graphite anode $\left(\mathrm{LiC}_{6}\right)$. The reason for that is lack of information on the ecoinvent database for $\mathrm{LiTi}_{5} \mathrm{O}_{12}$ anode. The results from the LCA will be analyzed and assumptions based on the literature will be made in order to get results that can be closer to reality.

\section{Electrolyte}

In this case the electrolyte is lithium hexafluorophosphate $\left(\mathrm{LiPF}_{6}\right)$ dissolved in ethylene carbonate (EC). The EC helps increase the electrolytes conductivity (The Electrochemical Society, 200). 


\section{Separator}

The cathode and anode of a battery must be physically separated in order to avoid electrical short during the flow of ions through the electrolyte. Therefore, a porous separator material, which allows the ions to flow through it, is used (M. Stanley Whittingham, 2004).

\section{Cell electronics}

The cell electronics were assumed to be a semiconductor that enables switching on and off and a resistor for temperature measurements.

\section{Transports}

Estimating transportation involves assumptions, since the cells come from china but the battery is built in Germany. The transportation from China to Germany would definitely have a high environmental impact if we consider transportation for only the battery cells. However, since the battery in this case is quite small, and would represent a small percentage of what is brought from China, we considered the impact of this transportation for this specific cells to be quite small.

The battery will be built in Braunschweig at ACTIA, which stays at a driving distance of $6,7 \mathrm{Km}$ from BS Energy. Considering that the battery would be transported by a light commercial vehicle, which would have an average $\mathrm{CO} 2$ emission of approximately $180 \mathrm{~g} / \mathrm{Km}$ (International Council on Clean Transportation, 2014), the total emissions for this transport would be approximately $1.200 \mathrm{gCO} 2$. This value considers that the car would go straight from ACTIA to BS energy to deliver the battery. To be conservative we considered a round trip, as if the vehicle would be used only for the battery transportation, and therefore the emissions would go up to $2.400 \mathrm{gCO} 2$, which is equal to $2,42 \mathrm{KgCO} 2$.

\section{Use Phase}

The system should comply with the charging of 5 from the 25 electrical cars. Considering that the battery capacity is only the equivalent to $50 \mathrm{Km}$, approximately the distance travelled per car per day, the efficiency of the battery 
can be considered to be of $20 \%$. Therefore, the cars may also receive energy directly from the PV system, in order to meet the energy demand.

The influence of the battery on the charging system was modeled using the following assumptions:

- The battery weight is of $160 \mathrm{Kg}$ and has a size of $0,3 \mathrm{~m}^{3}$;

- When fully charged, the battery can provide about $8 \mathrm{KWh}$, which is enough energy for $50 \mathrm{Km}$ of distance traveled;

- Each car travel around 50Km per day;

- $20 \%$ of charging efficiency was assumed, since it can provide enough energy for charging one car and the system should assist 5 vehicles;

- The internal efficiency of the battery is assumed to be $90 \%$;

- Lifetime of the battery was assumed to be 5 years. The company ACTIA $\mathrm{GmbH}$ says the lifetime can be over 5 years with the battery working at room temperature. The battery will be protected with a case, however, when dealing with environmental impacts it is important to be conservative and consider the worst scenario;

- Since the time period considered in this study is of one year and the lifetime of a typical Li-ion battery with a graphite anode is about 5 years, the battery weight is be divided by 5 in the calculation in order to provide consistent results. However, even though the battery from the model has a graphite anode, the real battery is a lithium titanate, which has a life time that ranges between 10 and 15 years. Therefore, 3 different scenarios were made, considering a 5-year lifetime, 10-year and 15-year lifetime. The idea is not only to bring results closer to the reality, but also to understand how big the battery lifetime impact on total LCA result is.

\section{End of Life}

As previously mentioned, the end of life of Li-ion batteries is one of its life cycle phases that deserve the biggest attention, since there is still no established technology for the recuperation of lithium and other active materials, in a way that they could be reintroduced in the production chain. The battery from this case study will be recycled by the Lithorec project, which was developed by TU 
Braunschweig in partnership with the Institute for Innovation and Technology.

The project structure is detailed in the following Figure, Figure 5.5:

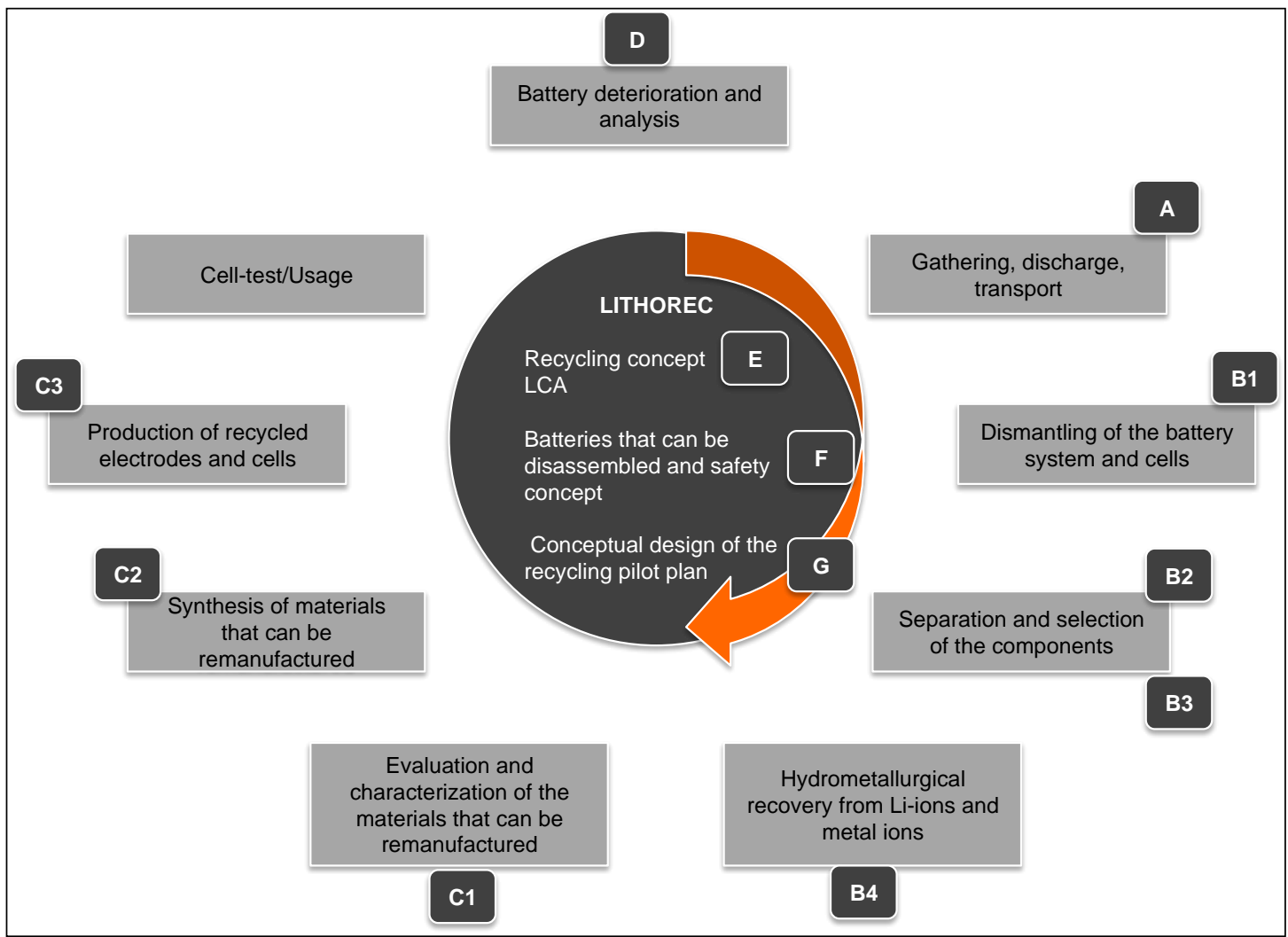

Figure 5.5 - Structure of the recycling process of the battery

Source: Lithorec, 2015.

The project is still being developed in order to find the best solution for recovering all the battery materials. The project phase A intends to analyze the battery and define the logistic process for its recycling. On the phase B different processes are used to dismantle the battery, including mechanical, chemical and hydrometallurgical. The use of the different types of technology for the dismantling is a way of verifying which methodology provides better results. During phase $\mathrm{C}$ the process of remanufacturing is developed, which means that the material that can be reintroduced on the production chain are identified and tested, and new cells are produced.

Phases D to F occur at the same time as the previous phases, it is the research part, which gives base for the execution of the whole process. The phase $\mathrm{D}$ analyzes the battery aging aiming the prolongation of the battery lifetime. Phase 
E makes an evaluation of the economic and environmental impacts of recycling the battery in order to find an optimal process model. Phase E stands for the development of the dismantling process, development of the security concept and development and documentation of the standards for all the phases of the recycling process. Finally, phase $\mathrm{G}$ is where the pilot plan for the whole recycling process is put together, taking into account the findings made on the previous phases.

\subsubsection{Results}

In this part of the case study, we consider that the battery station, which consists of a stationary battery, the PV system and one server, will provide enough energy for charging one car per day during one year. The charging of the other 4 cars will be analyzed considering two different scenarios, one with 2 of them being charged by the solar panel, since the energy from the solar panel for one car is already taken for the battery, and the other two being charged with energy form the grid. This scenario is shown for a 5, 10 and 15-year lifetime battery.

\section{Global warming potential (GWP)}

The global warming potential considering the charge of one vehicle by a 5year lifetime battery, which receives energy from the PV system, corresponds to $813 \mathrm{~kg} \mathrm{CO} 2-\mathrm{Eq}$. If transportation is included this value increases to $815 \mathrm{~kg} \mathrm{CO} 2-$ Eq. If other 2 vehicles are charged by the PV system, which has a GWP of $148 \mathrm{~kg}$ $\mathrm{CO} 2-\mathrm{Eq}$ and the 2 remain are charged with energy from the grid, with a GWP of $3.940 \mathrm{~kg} \mathrm{CO} 2-\mathrm{Eq}$ the total GWP would be circa $4.900 \mathrm{~kg} \mathrm{CO} 2-\mathrm{Eq}$.

If the battery would last 10 years, which would be the expected for a lithium titanate battery, its GWP for charging 1 vehicle would be $736 \mathrm{~kg} \mathrm{CO} 2-\mathrm{Eq}$, bringing the total potential down to $4.830 \mathrm{~kg} \mathrm{CO} 2-\mathrm{Eq}$. On the best scenario, the battery would achieve its maximum life time period, of 15 years, which means a GWP of $710 \mathrm{~kg} \mathrm{CO} 2-\mathrm{Eq}$, yielding a total potential of $4.800 \mathrm{~kg} \mathrm{CO} 2-\mathrm{Eq}$. 


\section{Ozone depletion}

Following the same logic, the ozone depletion potential for charging one car with energy from the battery station, considering a 5-year battery, is $9,6 \times 10^{-}$ ${ }^{5} \mathrm{Kg} \mathrm{CFC}^{-11}$ eq. With 2 vehicles being charged by the PV system that has an ozone depletion potential of $3,5 \times 10^{-5} \mathrm{Kg} \mathrm{CFC}^{-11} \mathrm{eq}$ and 2 other being charged by the grid, which presents an ozone depletion potential of $32 \times 10^{-5} \mathrm{Kg} \mathrm{CFC}^{-11} \mathrm{eq}$, the total ozone depletion potential would correspond to $45,1 \times 10^{-5} \mathrm{Kg} \mathrm{CFC}^{-11} \mathrm{eq}$.

Considering that the battery would last 10 years, implying an ozone depletion potential of $8,1 \times 10^{-5} \mathrm{Kg} \mathrm{CFC}^{-11} \mathrm{eq}$, and the total potential would be $43,6 \times 10^{-5} \mathrm{Kg} \mathrm{CFC}^{-11}$ eq. In case of optimum performance, lasting 15 years, its ozone depletion potential would correspond to $7,6 \times 10^{-5} \mathrm{Kg} \mathrm{CFC}^{-11} \mathrm{eq}$, yielding a total potential of $43,1 \times 10^{-5} \mathrm{Kg} \mathrm{CFC}^{-11} \mathrm{eq}$.

\section{Photochemical smog}

The photochemical smog potential for the charge of one vehicle a 5-year battery corresponds to $3.42 \mathrm{~kg}$ NMVOC. To charge 2 vehicles with energy provided by the PV system there is a photochemical smog potential of $0.63 \mathrm{~kg}$ NMVOC .To charge the 2 remaining cars with energy from the grid the photochemical oxidant formation is of $4.22 \mathrm{~kg}$ NMVOC. Therefore the total photochemical smog potential in this case would correspond to $8.27 \mathrm{~kg}$ NMVOC.

For a 10-year battery, which has a photochemical smog potential of 2.99 $\mathrm{kg}$ NMVOC, the total potential would be $7.84 \mathrm{~kg}$ NMVOC. A 15-year battery would have a photochemical smog potential of $2.85 \mathrm{~kg}$ NMVOC, and therefore the total potential would be $7.70 \mathrm{~kg}$ NMVOC.

\section{Acidification}

Charging one car using the battery system, which a 5-year lasting battery, has an acidification potential of $6.60 \mathrm{~kg} \mathrm{SO} 2-\mathrm{Eq}$. If 2 cars are charged straight by the PV system, with acidification potential of $0.87 \mathrm{~kg} \mathrm{SO}-\mathrm{Eq}$, and the other 2 vehicles are charged by the grid, with acidification potential of $5.46 \mathrm{~kg} \mathrm{SO} 2-\mathrm{Eq}$, the total acidification potential would be $12.90 \mathrm{~kg} \mathrm{SO} 2-\mathrm{Eq}$.

A battery with a lifetime of 10 years would have an acidification potential corresponding to $5.53 \mathrm{~kg} \mathrm{SO} 2-\mathrm{Eq}$, implying a total potential of $11.90 \mathrm{~kg} \mathrm{SO} 2-\mathrm{Eq}$. 
If the battery had a lifetime of 15 years, its acidification potential would be 5.17 $\mathrm{kg} \mathrm{SO} 2-\mathrm{Eq}$, bringing the total potential down to $11.50 \mathrm{~kg} \mathrm{SO} 2-\mathrm{Eq}$.

\section{Eutrophication}

The marine eutrophication potential for charging one car using a 5-year lasting battery, which is fed with energy from the PV system, corresponds to 0.34 kg N-Eq. In case of 2 vehicles being charged by the PV system, which has a marine eutrophication potential of $0,05 \mathrm{~kg} \mathrm{~N}-\mathrm{Eq}$, and the other 2 cars being charge by the German energy mix, with an eutrophication potential of $0,40 \mathrm{~kg} \mathrm{~N}-\mathrm{Eq}$, the total marine eutrophication potential would correspond to $0,79 \mathrm{~kg} \mathrm{~N}-\mathrm{Eq}$.

In case of a 10-year lifetime battery, with a marine eutrophication potential of $0.31 \mathrm{~kg} \mathrm{~N}-\mathrm{Eq}$, the total potential would be $0.76 \mathrm{~kg} \mathrm{~N}$-Eq. Furthermore, with a battery that lasts 15 years, which would have a marine eutrophication potential of $0.30 \mathrm{~kg} \mathrm{~N}-\mathrm{Eq}$, the total marine eutrophication potential would be $0.75 \mathrm{~kg} \mathrm{~N}$-Eq.

The freshwater eutrophication potential for charging one vehicle by a battery with a 5-year lifetime corresponds to $0.52 \mathrm{~kg}$ P-Eq. The freshwater eutrophication potential for charging 2 vehicles with the PV system corresponds to $0.02 \mathrm{~kg} \mathrm{P}-\mathrm{Eq}$, and for charging 2 vehicles with the energy from the grid it corresponds to $0.50 \mathrm{~kg}$ P-Eq. Therefore the total freshwater eutrophication potential for this scenario would be $1.04 \mathrm{~kg}$ P-Eq.

When having a battery with a 10-year lifetime, which has a freshwater eutrophication potential of $0.43 \mathrm{~kg}$ P-Eq, the total potential would be $0,95 \mathrm{~kg} \mathrm{P}$ Eq. If the battery lasts 15 years, which implies a freshwater eutrophication potential of $0.40 \mathrm{~kg} \mathrm{P}-\mathrm{Eq}$, the total potential would correspond to $0,92 \mathrm{~kg}$ P-Eq.

\subsection{Graphic comparison between different scenarios}

In this section all the results of the different scenarios, and for each impact category separately, are put into graphics in order to facilitate the interpretation.

The Figure 5.6 shows the GWP for the different scenarios presented. In all the scenarios the energy from the German electricity net has a great impact. The GWP has its lowest value when 3 vehicles are charged by the PV system and 2 by vehicles charged the grid. The second best option is the 15 -year lifetime battery combined with the photovoltaic energy and the grid. However, to be conservative, 
it should be considered that the battery wouldn't reach its maximum lifetime, and therefore the 10-year lifetime scenario would be closer to reality. Furthermore, the impact between the 10-year lifetime battery and 15-year lifetime is not significantly different for comparison purposes.

Thus, knowing that without storage the most likely scenario for the PV system would be having 2 vehicles charged by the solar energy and 3 by the grid, it would be preferable to have the battery system, ensuring the maximum use of solar energy.

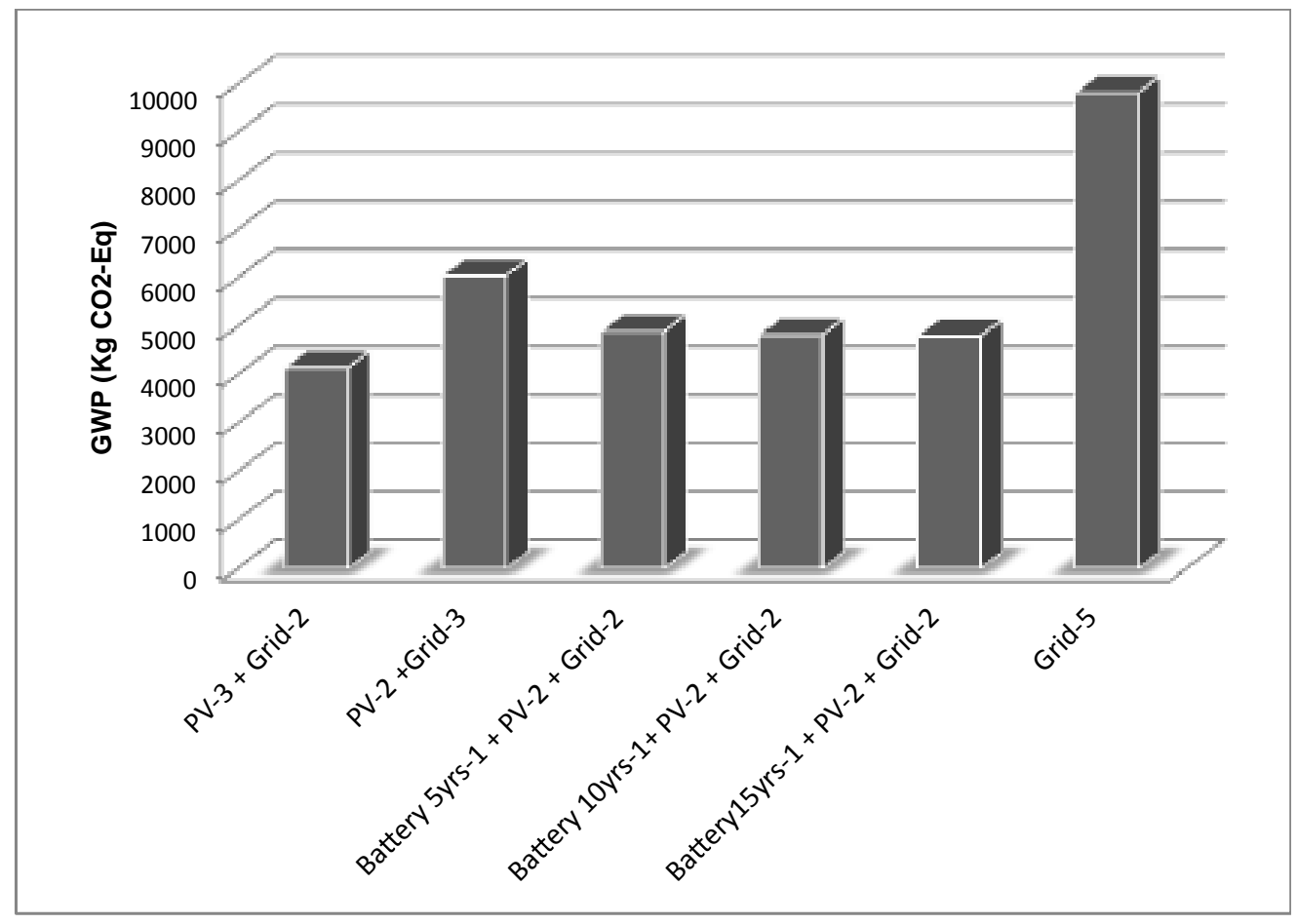

Figure 5.6 - GWP of the 6 different scenarios (in Kg CO2-Eq)

On Figure 5.7 the ozone depletion potential for each scenario can be observed. Here it can be seen that the use of electricity from the grid has also a very high impact, making it necessary to ensure the maximum use of the solar energy. The PV system use could be optimized by having the system telling the period of the day during which the cars should be charged, or by having the battery system. Even though the battery increase emissions, it is a lower increase than when the grid is used for charging another vehicle. 


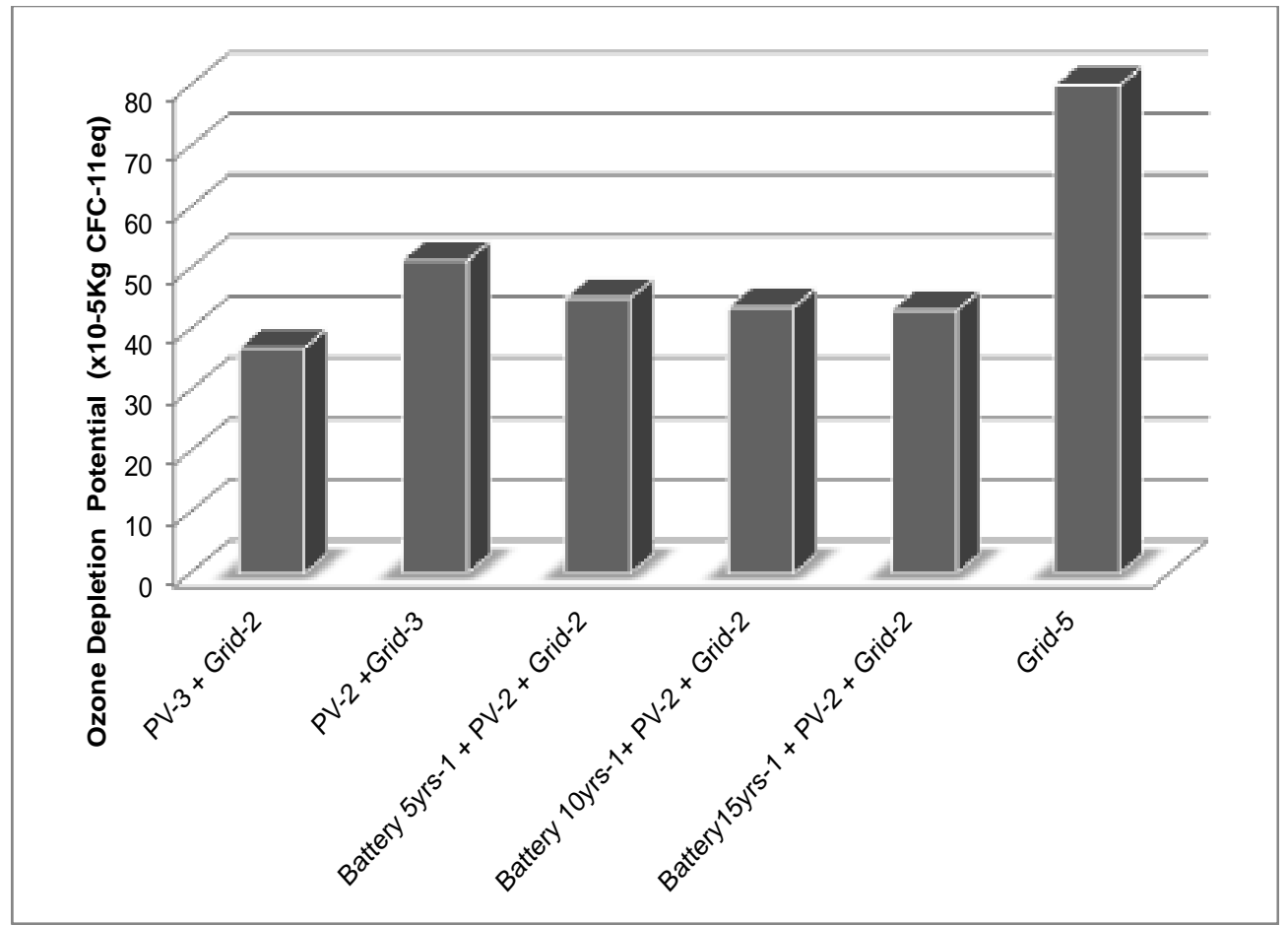

Figure 5.7 - Ozone depletion potential of the 6 different scenarios $(x 10-5 \mathrm{Kg}$ CFC-11eq)

The photochemical smog potential, as shown in Figure 5.8, is also very sensitive to the use of net energy. However, in this case the battery has a greater impact than the energy provided from the grid, which means that even for the worse PV scenario it would be better having only the PV system and the grid, without storage. However, since for charging 2 vehicles a day, the average solar energy generation needed during one month corresponds to $480 \mathrm{KWh}$, the PV system would, on average, only be able to charge 2 vehicles between March and end of September, when the solar generation is higher. During the other five months the PV system produce enough energy for charging only one vehicle and the energy left would not be enough to be worthy having the battery. But, if in a future scenario the PV system was expanded, the battery could be considered as an option for optimizing the use of solar energy produced. 


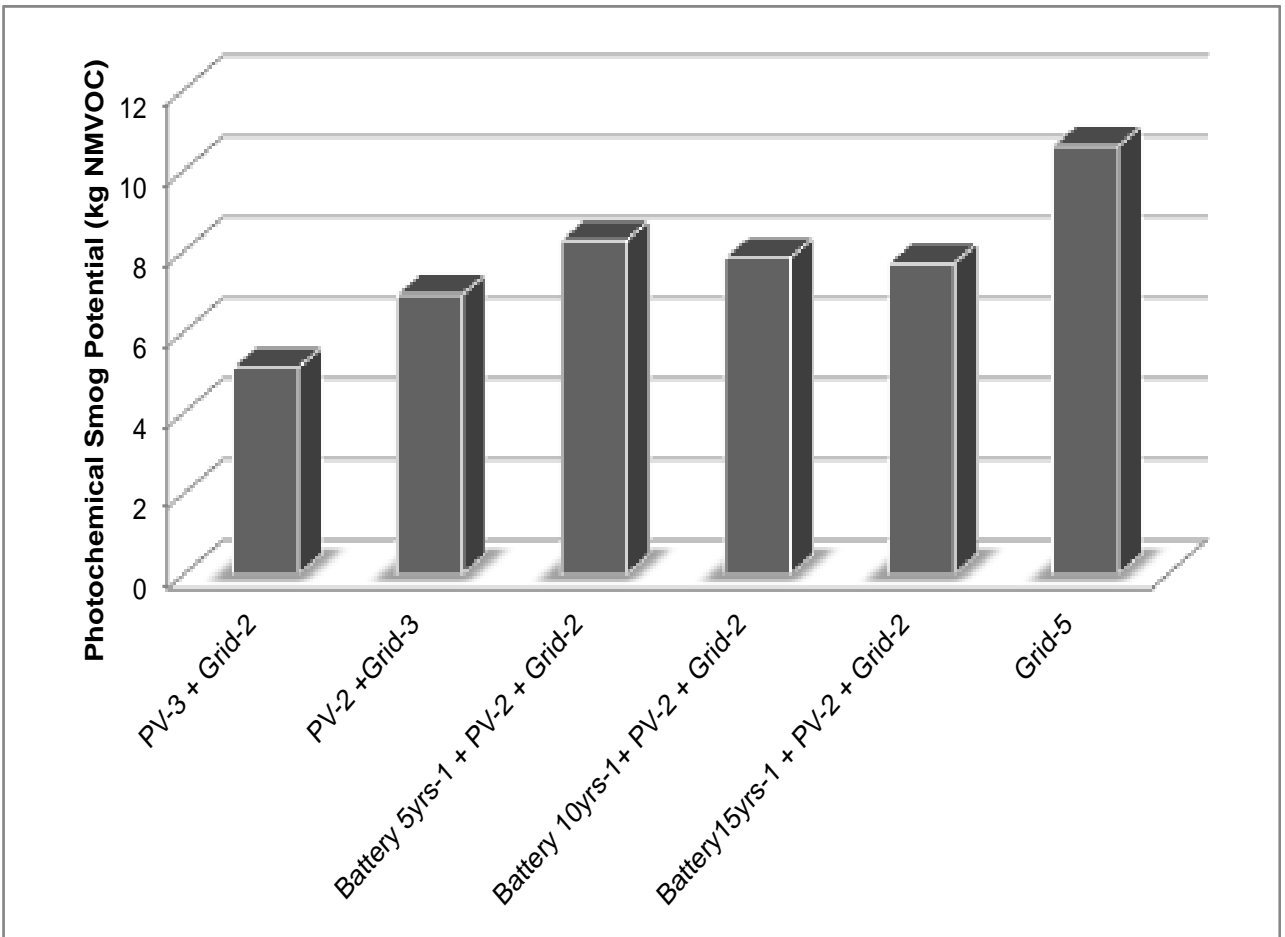

\section{Figure 5.8 - Photochemical smog potential of the 6 different scenarios (in $\mathrm{Kg}$ NMVOC)}

The same situation is observed for the acidification potential, Figure 5.9. In this case, the impact caused by the battery is even higher than observed on the photochemical smog potential. In order to avoid a high acidification potential would be important to make sure that the use of the solar energy generated is optimized, despite the absence of a battery.

The Figure 5.10 shows the marine eutrophication potential for all the different scenarios. This impact category presents a similar situation as the photochemical smog, where having the storage system wouldn't be environmentally worthy, unless the PV system was expanded. 


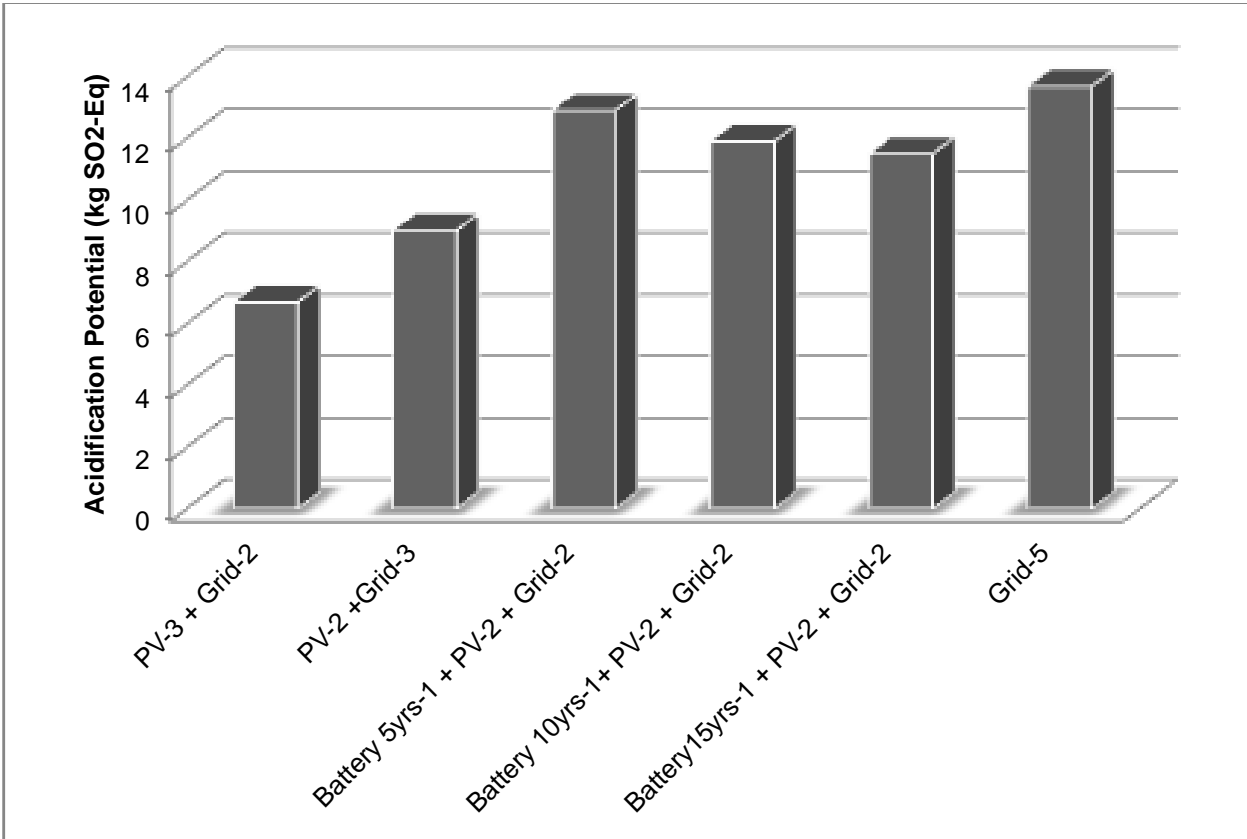

Figure 5.9 - Acidification potential of the 6 different scenarios (in $\mathrm{Kg} \mathrm{SO} 2$ Eq)

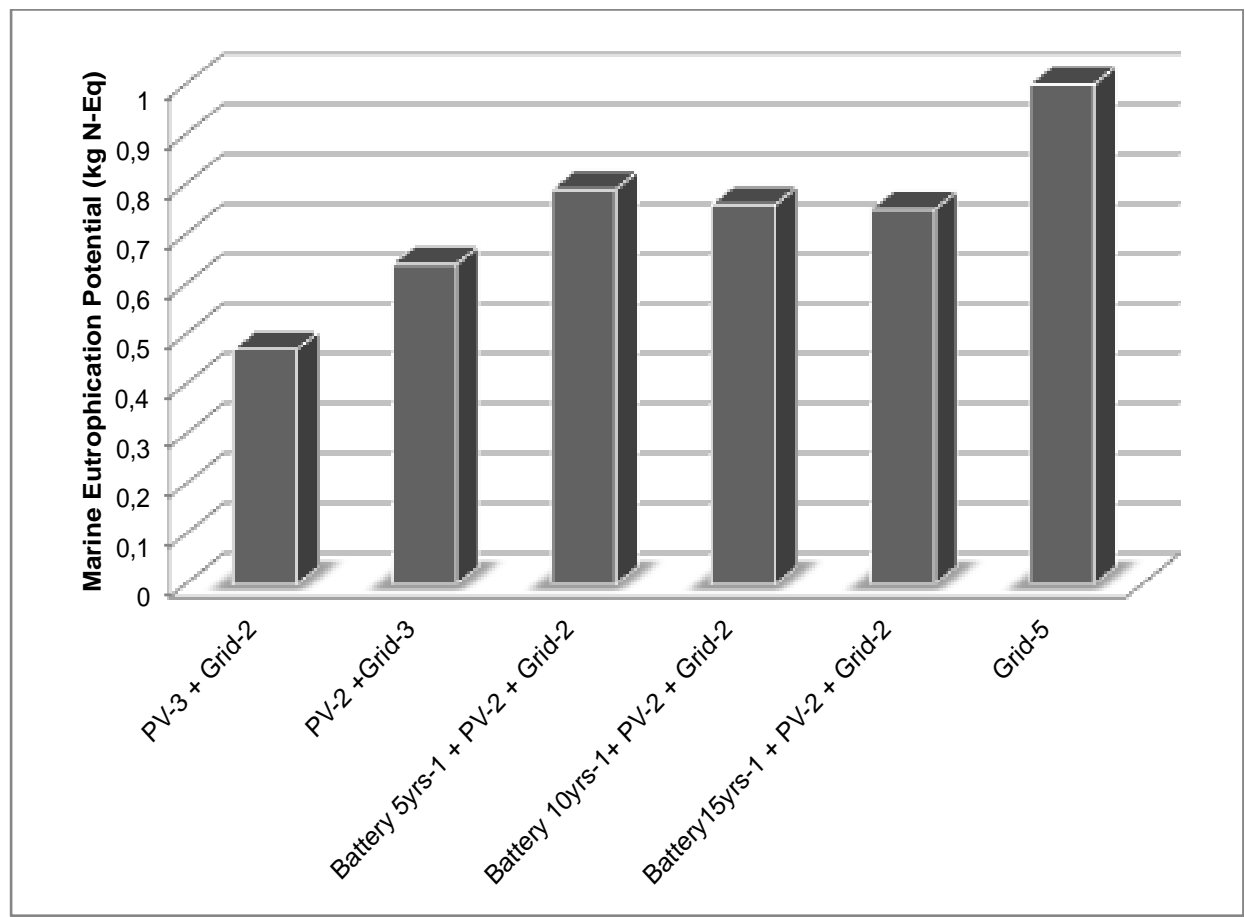

Figure 5.10 - Marine eutrophication potential of the 6 different scenarios (in $\mathrm{Kg} \mathrm{N}-\mathrm{Eq}$ )

The same situation can be observed for the freshwater eutrophication potential, Figure 5.11, where the battery has also great influence, even though a bit lower than the influence from the grid. The combination PV system plus grid is better than having a storage system. 


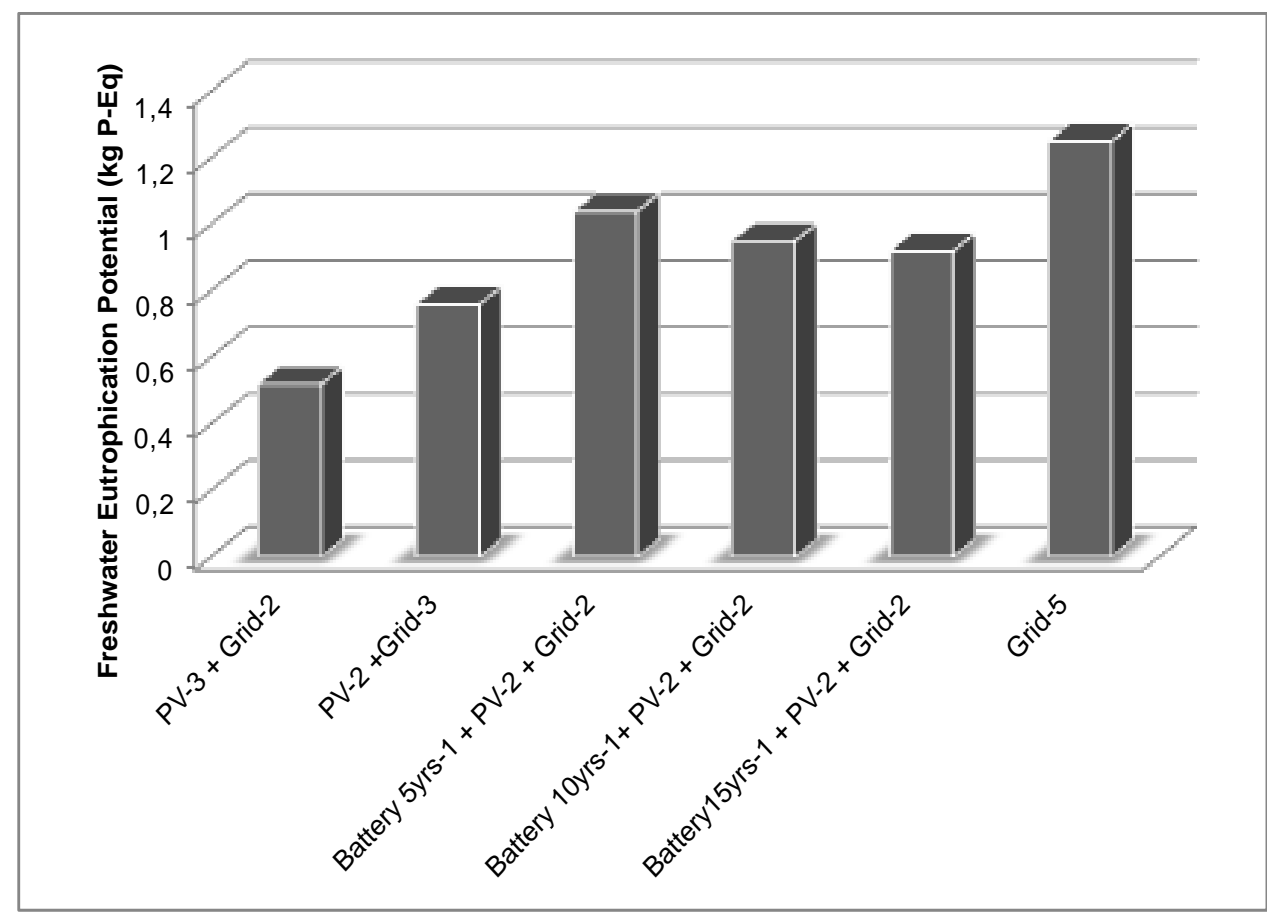

Figure 5.11 - Freshwater eutrophication potential (in Kg P-Eq)

\subsection{Future Scenario}

Electricity is an essential part of everyday life, and therefore vital to the economy. Both customers and firms rely on electricity for all kinds of activities, which means that improvements of the electricity production chain are essential for reducing the environmental impact of these activities. Furthermore, the renewable energy generation on large scale has a big advantage when compared to small-scale local energy production, which is the fact that all the energy generated will go straight to the grid and most of it will be consumed minimizing losses, especially in countries like Germany, where losses on transmission are very low, of about $4 \%$. This reduces the need of storage, and by consequence the consumption of raw material and production of waste.

Locally generated renewable energy, however, has become more interesting, from both an economic and environmental point of view, with the growth of smart grid systems. With these systems, the surplus locally generated renewable energy could feed the grid without the need for storage, reducing the environmental impact of the grid.

When it comes to vehicles in general, the energy used to feed them is crucial for the definition of their environmental impact. As shown in Figure 5.12, 
while the end of chain emissions from combustion light duty vehicles is of about $130 \mathrm{~g} / \mathrm{Km}$, vehicles charged by renewable energy have no end of chain emissions. Thus, the higher the share of renewable energy on the electricity net of a country, the lower the impact of its products or services.

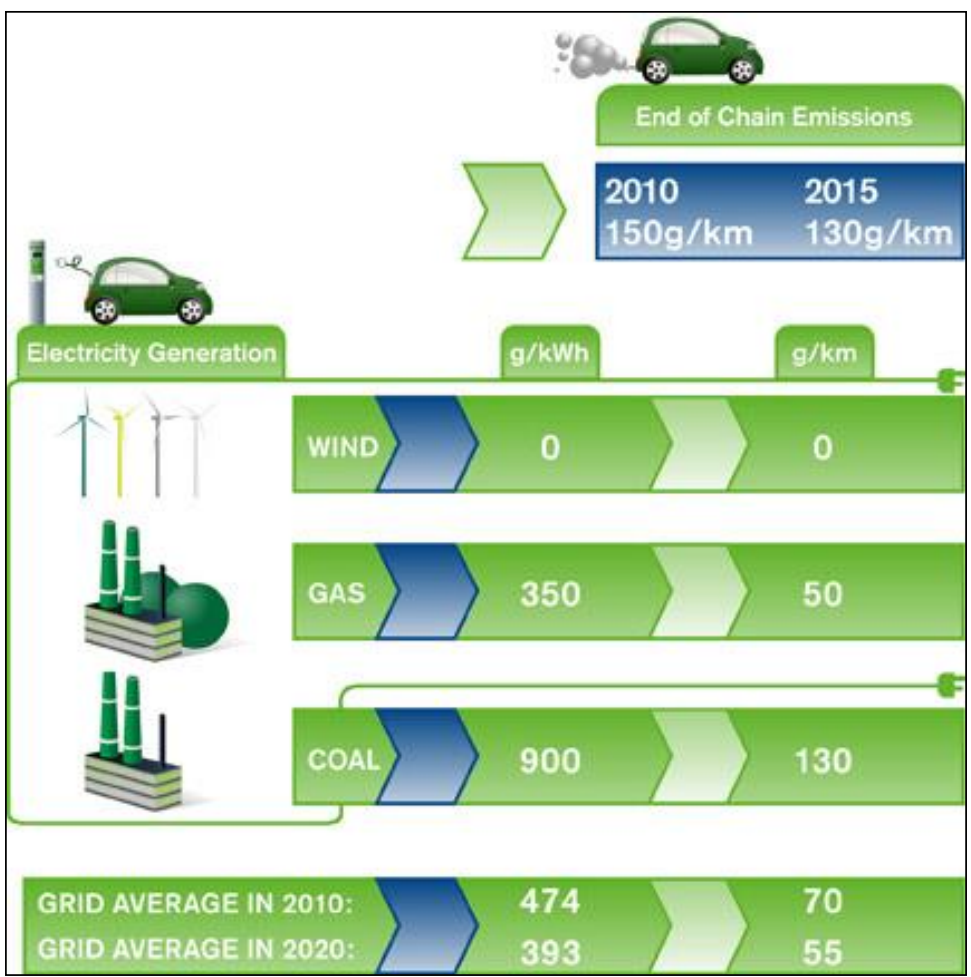

Figure 5.12 - Scheme of vehicles end of chain emissions considering different energy sources

Source: ESB ecars, 2014

Germany has the target of having $45 \%$ of renewables on its energy production chain by 2025. As mentioned on chapter 2, the current German electricity net counts with a generation from renewable sources of $29.70 \%$. Thus, if the target of having $45 \%$ of renewables on the electricity net by 2025 is achieved, the end of chain emissions would technically drop 15,30\%, which, for our case study, would mean a GWP for charging one vehicle during one year corresponding to $1.670 \mathrm{~kg} \mathrm{CO} 2-\mathrm{Eq}$, instead of $1.970 \mathrm{~kg} \mathrm{CO} 2-\mathrm{Eq}$. This still represents a higher impact than both the PV system and the storage system from the case study. The end of chain emissions would have to drop $51 \%$ in order for the use of only grid energy to be a better option. 


\section{SUMMARY AND OUTLOOK}

Considering the current German electricity mix, the energy provided from the grid has shown a greater impact than both the photovoltaic system and the battery station, in regard of the global warming potential and ozone depletion potential. However, for all the scenarios, the energy from the grid is necessary to complement the energy generated from the solar panel, since the PV system provides on total an average of $9.480 \mathrm{KWh}$ per year, enough for charging only 3 out of 5 vehicles during the year.

Nevertheless, in some cases, the combination PV plus battery station plus grid, does not seem attractive when compared with the combination PV system plus grid. This situation was observed for the following impact categories: photochemical smog potential, acidification potential and eutrophication potential (both marine and freshwater). Considering the charge of one vehicle, on impact category photochemical smog potential, the 10-year lifetime battery has shown an impact 35\% higher when compared with the energy provided by the grid. On the acidification potential the impact of the 10 -year lifetime battery is $97 \%$ greater than the energy from the German electricity net. For the marine and freshwater potentials, the impact of the battery is respectively $53 \%$ and $75 \%$ higher when compared to the impact of the energy from the grid for charging one vehicle. As observed on the charts from section 5.6, if the battery used was a Li-ion battery with a graphite anode the impact would be even higher.

Due to the fact that lithium titanate batteries last longer when compared to Li-ion batteries with the graphite anode, the scenario where the battery lasts 10 years should be considered. A battery life of 15 years would be an optimum scenario, but not a conservative one. Furthermore, the difference between the impact of the 10-year and a 15-year lifetime battery, for all the impact categories, is not substantial, differently from the impact between the 5-year and the 10-year lifetime battery.

Differently from the situation observed for the photochemical smog, acidification and eutrophication potentials, the energy from the grid has shown an impact 2.8 times higher than the impact of the battery in regard of the global warming potential. When it comes to ozone depletion potential the grid also 
represents a much greater impact when compared to the battery, corresponding to 2.3 times the impact of the battery.

As mentioned on section 4, the decision of whether to prioritize one impact category over another is not always simple. Even though three of the impact categories, photochemical smog, acidification potential and eutrophication potential, have shown an unfavorable scenario for the battery acquisition, the priorities of each country in relation to the prevention and mitigation of environmental impacts should be considered. Taking into account the geographical setting of Germany, the global warming potential and ozone depletion potential may have greater influence on the decision making than the other impact categories.

The battery is therefore an option that should be considered to optimize the use of the generated solar energy. Another option to be taken into account is to design the reloading of vehicles during periods of intense solar power generation; however, this option may not always be the most effective due to uncertainty about the periods of the day that the fleet may be required to be used. Finally, since the PV system has shown the best environmental performance when compared to the use of the German electricity net, it should be considered the possibility of expanding the local energy generation in order to guarantee a low end of chain emissions of the vehicle fleet.

As future work it could be interesting doing a multifunctional analisys of this system, since diferent scenarios are being considered. Another suggestion as future study is to make this kind of LCA for countries with higher solar irraditaion and more renewable electricity net, such as Brazil, including an economical analysis. This type of study could estimulate the investment on local renewable energy production and on the development of EVs market in the country. 


\section{REFERENCES}

AGORA ENERGIEWENDE, Entwicklung der Windenergie in Deutschland, Available at http://www.agoraenergiewende.org/topics/optimisation-of-the-overall-system/detailview/article/optimierte-windenergieanlagen-bieten-vorteile-fuer-dasstromsystem/, last accessed November 14, 2014.

BATTISTI R. AND CORRADO A., Evaluation of technical improvements of photovoltaic systems through life cycle assessment methodology. Energy. June 2005.

BAUMANN, H., 1992. LCA: Utvärdering med index. Beräkning av tva uppsättningar norska index. CIT-ekologik 1992:2. Chalmers, Gothenburg.

BURGER B., Electricity production from solar and wind in Germany in 2014 , http://www.ise.fraunhofer.de/en/downloads-englisch/pdf-filesenglisch/data-nivc-/electricity-production-from-solar-and-wind-in-germany2014.pdf, accessed in February 2015.

CHAN C. C., The State of the Art of Electric, Hybrid, and Fuel Cell Vehicles Proceedings of the IEEE, Vol. 95, No. 4, April 2007

CHAPMAN L., Transport and climate change: a review, Journal of Transport Geography, Elsevier, September 2007.

DARYL L. AND HARVEY D., Energy Efficiency and the Demand for Energy Services, Dunstan House London: Earthscan Ltd., 2010.

ELECTROCHEM J., the Effect of Ethylene Carbonate and Salt Concentration on the Conductivity of Propylene Carbonate|Lithium Perchlorate Electrolytes, J. Electrochem. Soc, 2000. [8] Gaines L., Dunn J., Lithium-ion Battery Environmental Impacts, in Lithium-ion Batteries: Advances and Applications, Elsevier, 2014. 
ESB, http://www.esb.ie/electric-cars/environment-electric-cars/how-greenare-electric-cars.jsp, accessed on February 10, 2015.

FINNVEDEN G, HAUSCHILD MZ, EKVALL T, GUINÉE J, HEIJUNGS R, HELLWEG S, et al. Recent developments in life cycle assessment. Journal of Environmental Management 2009.

FRAUNHOFER ISE, Recent Facts about Photovoltaics in Germany, http://www.ise.fraunhofer.de/en/publications/veroeffentlichungen-pdf-dateienen/studien-und-konzeptpapiere/recent-facts-about-photovoltaics-in-germany.pdf, , last updated on January 7 2015, accessed on January 152015.

GAINES, L.; DUNN, J., Lithium-Ion Battery Environmantal Impacts, Argone National Laboratory, Center for Transportation Research, USA, 2014.

GAINES, L., NELSON, P., 2009. Lithium Ion Batteries: Possible Materials Issues. Argonne National Laboratory.

GAINES, L.; SULLIVAN, J.; BURNHAM, A.; Life-Cycle Analysis for Lithium-Ion Battery Production and Recycling, Argonne National Laboratory, USA, Paper No 11-3891, Submitted August 1, 2010.

GERMAN WIND ENERGY ASSOCIATION, http://www.windenergie.de/, accessed on November 24, 2014.

GIULIANO M.; ADVANI S.; PRASAD A., Thermal Analysis and Management of Lithium-titanate Batteries, Elsevier, Center for Fuel Cell Research, Department of Mechanical Engineering, University of Delaware, United States, 2011.

GUINÉE, J.; GORRÉE, M.; HEIJUNGS, R.; HUPPES, G.; RENÉKLEIJN; KONING, A.; OERS, L.; SLEESWIJK, A.; SUH, S.; HAES, H., Handbook on Life Cycle Assessment, Operational Guide to the ISO Standards, Kluwer Academic Publishers, USA, 2004.

HIREMATH M., Comparative Life Cycle Assessment of Stationary Battery Storage Technologies for Balancing Fluctuations of Renewable Energy 
Sources, March 2014, Master Thesis, Postgraduate Program Renewable Energy (PPRE) Carl von Ossietzky University of Oldenburg, Germany.

IDAHO NATIONAL LABORATORY, Advanced Vehicle Testing Activity, http://avt.inel.gov/pdf/fsev/costs.pdf, last access on February 16, 2015.

INTERNATIONAL ENERGY AGENCY, Life Cycle Inventories and Life Cycle Assessments of Photovoltaic Systems, LCA Report IEA-PVPS Task 12, Subtask 20, October 2011.

INTERGOVERNMENTAL PANEL ON CLIMATE CHANGE, Special Report on Renewable Energy Sources and Climate Change Mitigation, Technical Support Unit Working Group III, Potsdam Institute for Climate Impact Research, May 2011.

INTERNATIONAL ORGANIZATION FOR STANDARDIZATION, Environmental management, The ISO 14000 family of International Standards, ISO/TC 207, 2009.

JUNGBLUTH N.; BAUER C.; DONES R. AND FRISCHKNECHT R., Life Cycle Assessment for Emerging Technologies: Case Studies for Photovoltaic and Wind Power, ecomed publishers (Verlagsgruppe Hüthig Jehle Rehm GmbH), 2004.

LITHOREC, lithorec.de, accessed on March 01, 2015.

MATHEYS, J., VAN AUTENBOER, W., Timmernans, J.; Mierlo, J.; Bossche, P.; Maggetto, G., 2007. Influence of functional unit on the life cycle assessment of traction batteries. The International Journal of Life Cycle Assessment 12 (3), 191: 196.

NAISH, C., MCCUBBIN, I., EDBERG, O., HARFOOT, M., 2008. Outlook of Energy Storage Technologies. European Parliament, Policy Department Economic and Scientific Policy.

NAKICENOVIC, N., SWART, R., 2000. IPCC Special Report: Emissions Scenarios. Cambridge University Press, UK, pp. 570. 
NELSON P. AND AMINEB K., Advanced Lithium-Ion Batteries for Plug-in Hybrid-Electric Vehicles, Nova Science Publishers, Argonne National Laboratory, USA, 2010.

PROGRESS IN PHOTOVOLTAICS: RESEARCH AND APPLICATIONS Prog. Photovolt: Res. Appl. 2005; 13:235-250 Published online 14 January 2005 in Wiley InterScience (www.interscience.wiley.com), accessed on November 132014.

RYDH, C.J., SANDÉN, B.A., 2005a. Energy analysis of batteries in photovoltaic systems. Part I: performance and energy requirements. Energy Conversion and Management 46 (11e12), 1957e1979.

SUNNY PLACES, www.sunnyplaces.com, access on February 6, 2015

TENNESSEE VALLEY AUTHORITY, Types of Electric Vehicles http://www.tva.gov/environment/technology/car_vehicles.htm, 2015.

THE AMERICAN CHEMICAL SOCIETY, Chemical Reviews, Vol. 104, No. 10, 2004.

TIAN B.; XIANG H.; ZHANG L.; LI Z.; WANG H., Niobium doped lithium titanate as a high rate anode material for Li-ion batteries, School of Chemistry \& Chemical Engineering, South China University of Technology, , China, 2010.

UNITED NATIONS ENVIRONMENT PROGRAMME, Towards a Life Cycle Sustainability Assessment, Making informed choices on products, UNEP/SETAC Life Cycle Initiative, 2011.

VINODKUMAR ETACHERI, ROTEM MAROM, RAN ELAZARI, GREGORY SALITRA AND DORON AURBACH, Department of Chemistry, Bar-Ilan University, Ramat-Gan, 52900, Israel, 2011.

WATSON, R.T., 2001. IPCC Special Report: Climate Change 200: Synthesis Report. Cambridge University Press, UK, pp. 398. 
WHITTINGHEM M., Lithium Batteries and Cathode Materials, Chemical Reviews, 104 (10), pp 4271-4302, American Chemical Society, New York, September 14, 2004.

WORLD BUSINESS COUNCIL FOR SUSTAINABLE DEVELOPMENT, WBCSD, Responding to the Biodiversisty Challenge, 2001.

WORLD NUCLEAR ASSOCIATION, http://www.worldnuclear.org/info/Country-Profiles/Countries-G-N/Germany/, accessed on September 20, 2014.

ZACKRISSON M., AVELLÁN L. AND ORLENIUS J., Life cycle assessment of lithium-ion batteries for plug-in hybrid electric vehicles, Critical issues, Journal of Cleaner Production, Volume 18, Issue 15, November 2010, Pages 1519-1529, 2015

ZIESING J., Energieverbrauch in Deutschland im Jahr 2013, AG Energiebilanzen e.V., March 2014. 